\title{
A REPÚBLICA DOS ANTIGOS E A REPÚBLICA DOS MODERNOS
}

Tese de doutoramento do aluno Paulo Levorin do Departamento de Ciência Política da Faculdade de Filosofia, Letras e Ciências Humanas da Universidade de São Paulo (FFLCH/USP), sob orientação do Prof. Dr. Gabriel Cohn. 


\section{$\underline{\text { RESUMO }}$}

A primazia da economia sobre a política, aceitação natural no debate político atual, tem levado ao abandono progressivo da idéia do público e do bem comum, ou seja, da essência mesma da política, reduzindo-a a um arranjo institucional com o intuito de possibilitar uma competição pacífica entre os diversos grupos que formam a sociedade em defesa de seus interesses privados. O intuito destas linhas é retomar a essência obscurecida da política através das principais linhagens do republicanismo clássico, comparando-o com o constitucionalismo, em sua origem.

\section{$\underline{\text { ABSTRACT }}$}

The primacy of economy over politics, a natural and self-evident acceptance in the present political debate, has been leading to the progressive abandonment of the idea of public and common welfare, that is, the real political's essence being reduced into a mere institutional arrangement with the purpose to make possible a pacific competition between the diverse groups that form society in defense of their private interests. The purpose of these lines is to regain the obscured essence of politics through the main lineages of the classical republicanism and, comparing it in its origins, to the constitutionalism. 
$\underline{\text { ÍNDICE }}$

INTRODUÇÃO

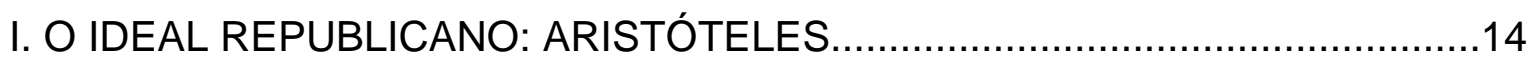

II. ESPARTA E ROMA: AS REPÚBLICAS DE POLÍBIO....................................33

III. FLORENÇA E VENEZA: LEONARDO BRUNI E OS TEÓRICOS RENASCENTISTAS DO GOVERNO MISTO.

IV. INGLATERRA: O NASCIMENTO DO CONSTITUCIONALISMO E A REPÚBLICA DE JAMES HARRINGTON. .98

V. AMÉRICA: MONTESQUIEU E A REVOLUÇÃO AMERICANA 130

BIBLIOGRAFIA 
INTRODUÇÃO

Existe uma concepção muito difundida de que o constitucionalismo moderno teria as suas origens na Antigüidade e, longe de haver uma ruptura entre o presente e o passado, haveria uma linha contínua. Evidentemente, acentuam, não se trata de uma identidade - visto que algumas características do presente estão ausentes no passado, como os Direitos Humanos -, mas sim de uma metamorfose, de uma adaptação de uma mesma forma de governo a novas condições (Sternberger, 1978, vol. I, 402). Para sustentar a tese de que a tradição política prevalecente no ocidente seria o constitucionalismo e desde a Antigüidade os homens perseguiriam o mesmo valor político, quer dizer, a liberdade - a liberdade da opressão política que o governo constitucional propiciaria -, os defensores desta concepção procuraram demonstrar: (a) que os fundadores da República Americana foram precedidos por uma doutrina constitucional antiga, a doutrina do governo misto - sistematizada pela primeira vez por Aristóteles e Políbio e perpetuada com poucas alterações, durante vários séculos por uma variedade enorme de escritores; (b) e que a República Americana, marco do constitucionalismo moderno, foi precedida por experiências constitucionais antigas - em particular, Esparta, Roma, as comunas italianas e a Inglaterra, justamente as mais significativas em sua época.

Dentre os autores que procuraram estabelecer as linhagens antigas do constitucionalismo moderno, a ênfase recai, como dissemos, em Aristóteles e em Políbio. Para a maior parte destes autores, foi Políbio quem introduziu, com o governo misto, entendido como um sistema de checks-andbalances, que marcou decididamente o pensamento constitucionalista antigo e os fundadores da República Americana. Políbio teria - com a concepção do sistema de pesos e contrapesos, apoiadas em seu estudo histórico de Esparta e Roma não só concebido uma forma mais elaborada e refinada de governo misto que os 
seus antecessores, como também se tornado referência para os teóricos do constitucionalismo antigo que Ihe sucederam (Cícero, em Roma; Tomás de Aquino e Ptolomeu de Lucca, na Idade Média; Maquiavel, Francesco Guicciardini, Bartolomeo Cavalcanti, Niccolò Sabellico, Gerolamo Garimberto, Giovanni Maria Memmo, Giasone de Nores, Pompeo Caimo, Donato Giannotti, Gasparo Contarini, Paolo Paruta, no Renascimento italiano; John Fortescue, Thomas Starkey, John Ponet, Thomas Smith, John Aylmer, Thomas Cartwrigth, Robert Parsons, Carlos Stuart, Philip Hunton, James Harrington, na Inglaterra; entre tantos outros) e para os fundadores do constitucionalismo moderno (Hasbach e Kägi são os pioneiros na formulação desta tese; Chinard, o primeiro a explorar detalhadamente a influência de Políbio não só nos Federalistas, mas em todos que participaram da discussão e da formação da Constituição americana; a estes se segue os trabalhos de Sabine, Dickinson, Friedrich, Rantzau, Loewenstein (1957), Hinton, Weston, Gummere, Hennis, Passarin d'Entreves, W.P. Adams, Mandt, Kuhfuß, Rostock, Rexine, Wember, d'Avack, Nippel (1980), Bobbio (1983 e 1985), Trapp e Bose). A concepção de governo misto de Políbio, prevendo uma separação das funções de governo entre os cônsules, os senadores e o povo (respectivamente, a parte monárquica, aristocrática e democrática de sua constituição) e o controle recíproco entre elas (para que cada instância fique limitada às suas atividades, evitando o abuso do poder), teria precedido a doutrina da separação e do controle recíproco dos poderes formulada pelos Federalistas. Para estes autores, apesar da afirmação aparentemente contrária de Madison "a América teve o mérito de descobrir para a humanidade as bases de uma república extensiva e não mista" ( $\left.\mathrm{N}^{\circ} 14\right)$ - a semelhança entre a constituição mista de Políbio e a constituição dos Federalistas seria notória. A república de Madison, segundo estes autores, não é mista no sentido que diferentes instituições políticas são distribuídas entre diferentes classes sociais, uma vez que, na América, "todo poder emana do povo" ( $N^{\circ} 37$ e $\mathrm{N}^{\circ} 63$ ). Os Federalistas, no lugar de separarem as instituições pelas classes sociais, como em Políbio (o Senado, representando os patrícios; a Assembléia, representando o povo), 
separaram as atribuições do governo, seguindo o princípio de que todo poder emana do povo, entre o Presidente (eleito indiretamente para representar a nação), os senadores (eleitos indiretamente para representarem cada um dos Estados da Federação) e os membros da Câmara dos Representantes (eleitos diretamente pelo povo para representarem o povo americano) - instituídos constitucionalmente do poder de se controlarem mutuamente ( $\mathrm{N}^{\circ} 39$ e $\left.\mathrm{N}^{\circ} 51\right)$. Deste modo, os Federalistas teriam chegado à mesma conclusão de Políbio: "a separação dos poderes é essencial à liberdade" ( $\left.N^{\circ} 51\right)$.

Para a outra parte deles, a mais recente, "a partir de Aristóteles podemos seguir uma linha clara e ininterrupta até os Federalistas" (Imboden (a), 10). Mesmo havendo indícios de uma doutrina do governo misto antes mesmo de Aristóteles (Zillig cita Tucídides, Xenofonte, Isócrates e Platão; Aalders (1968) vai mais longe ainda, procurando mostrar que tais indícios poderiam ser encontrados já nos pitagóricos), caberia a ele o mérito de ter formulado uma doutrina de governo misto com uma outra característica que se tornará parte integrante da república dos Federalistas - embora a sua influência não possa ser comprovada (este é o tema central das principais obras de Imboden, Sternberger, Kielmansegg, Riklin e Maier). Preocupado em evitar o domínio de uma determinada classe social sobre outra, Aristóteles teria proposto uma forma de governo na qual à mistura dos elementos sociais que compõem a sociedade (ricos e pobres) se associaria a mistura de elementos institucionais (oligárquicos e democráticos), com o fito de estabelecer um equilíbrio duradouro de poder entre as duas classes (no sentido que uma não poderia dominar a outra, evitando, portanto, quer a oligarquia, quer a democracia): os ricos (por não precisarem se dedicar às atividades de sustento) seriam alçados aos principais cargos públicos através da eleição (instituição oligárquica), enquanto os pobres (por não disporem de ócio) limitariam as suas atividades públicas à eleição dos magistrados (Aalders, 1968, 55; Sternberger, 1985 (a), 73-4). 
Como em Aristóteles, a constituição dos Federalistas poderia ser considerada mista se for levado em consideração que o poder não é exercido diretamente pelo povo, como na democracia pura (um regime de exclusão, "sempre assolado pelas desgraças da facção" ( $\left.N^{\circ} 10\right)$ ), mas pelos eleitos periodicamente pelo povo. Como em Aristóteles, segundo estes autores, o mandato dos eleitos seria fiduciário, isto é, caberia a eles decidir o que é bom para todos, não estando vinculados aos interesses específicos daqueles que o elegeram - ao contrário da delegação, típica das relações de representação dos governos mistos. Como em Aristóteles, este arranjo institucional impediria "que um grupo de interesse específico se sobreponha sobre os demais" ( $\mathrm{N}^{\circ} 39$ ); de modo que as facções (originadas pelos interesses particulares conflitantes dos membros que formam a sociedade) seriam através da representação balanceadas e a guerra civil (conseqüência última deste conflito entre as facções), portanto, evitada. Evidentemente, não cabe ao governo - isto não seria possível realizar concomitantemente todos os interesses, mas administrar o conflito entre eles; o que está em jogo é o estabelecimento de uma esfera livre do domínio (ou privilégios) de um grupo social sobre os outros, a esfera econômica, é a garantia da livre atuação, sem privilégios, de todos os diversos grupos sociais nesta esfera. Aristóteles seria, portanto, o precursor da concepção do "governo representativo" dos Federalistas - o único "remédio" eficaz contra as dissensões provenientes do conflito entre as facções, uma vez que a diversidade de faculdades nos homens torna "impraticável" uma solução que proponha proporcionar a todos os cidadãos as mesmas opiniões, as mesmas paixões, os mesmos interesses, além das mesmas propriedades ( $\left.N^{\circ} 10\right)$. Assim, segundo estes autores, as duas formas de mistura institucionais - a de Políbio (a solução para o abuso natural do poder pelos governantes) e a de Aristóteles (a solução também para as desgraças da facção) - se complementariam (sem levar em consideração a mistura social) na república dos Federalistas. Trata-se, portanto, de um reforço mútuo: a liberdade - entendida como ausência da opressão dos detentores dos cargos públicos ou de um determinado grupo social, como 
ausência do exercício abusivo do poder - seria garantida através da separação e do controle recíproco dos poderes e da representação (Riklin, 1987, 76-8 e 84-7). Em outras palavras, ao possibilitar que todos os grupos sociais possam livremente perseguir os seus interesses (conflitantes), forçando um equilíbrio entre eles - pensa-se, fundamentalmente, numa sociedade marcada pela concorrência economia -, este arranjo constitucional evitaria a imposição de um grupo de interesse sobre outros, isto é, evitaria a formação de uma tirania (seja de um, de uma minoria ou de uma maioria).

Evidentemente, a constituição dos Federalistas possui, conforme estes autores, outras características que a afastaria da dos antigos: a doutrina do governo federativo (a União, condição de realização do governo representativo pois quanto mais extensa a república, quanto maior é o grau de pluralismo na sociedade, menor é a força de um determinado grupo de interesse com relação aos outros), do Poder Judiciário (entendido como "baluarte da Constituição" ( $\mathrm{N}^{\circ}$ 78) e inspirado, certamente, nos juristas ingleses do passado como John Fortescue, Edward Coke, Henry Finch e John Davies, entre outros) e, principalmente, dos direitos individuais (contidos nos Bill of Rights das várias colônias americanas, entre 1776 e 1787). Enquanto as duas primeiras visavam reforçar ainda mais as garantias institucionais da liberdade da opressão de um poder arbitrário, a doutrina dos direitos individuais visava ampliá-la. Se, por um lado, a liberdade que os antigos e modernos visam seria a mesma, com a modernidade, a igualdade, entendida, fundamentalmente, como um direito de todos os homens de serem livres de qualquer opressão - tanto política como social, religiosa e, até mesmo econômica - passa a ser a universal, um direito natural que os antigos não reconheciam (Sternberger, 1985 (a), 64 e 71). Em outras palavras, a distinção entre estas doutrinas antigas (o ponto culminante do pensamento político grego, romano, renascentista e inglês) e o constitucionalismo moderno (iniciado na América dos Federalistas) seria quantitativa, e não qualitativa: as primeiras abrangeriam somente aqueles que atingiram o status de cidadão, o último, todos os homens. A transição do constitucionalismo antigo para 
o moderno se daria à medida que os Direitos Humanos se consolidam, estendendo um mesmo valor (a liberdade) a todos os homens (Friedrich, 6).

Como dissemos no primeiro parágrafo, parte destes autores se preocuparam em mostrar que o constitucionalismo moderno foi precedido e influenciado não somente pela doutrina constitucional antiga como também pelas experiências constitucionais antigas (em particular, Friedrich, Loewenstein (1973), Nippel e Riklin (1987)). Apesar de uma certa divergência a cerca da primeira experiência constitucional - alguns acreditam encontrá-la em Atenas, nos moldes descritos por Aristóteles (Zillig, 8-14; Aalders, 1968, 52-3) - as Repúblicas de Esparta e, principalmente, de Roma são tidas como exemplos de governo constitucional. Enquanto que historicamente seria difícil comprovar no passado um caso de governo constitucional nos moldes descritos por Aristóteles, senão Esparta, pelo menos Roma teria consolidado uma forma de governo precursora da separação dos poderes, coincidente, em seus pontos principais, com as descrições de Políbio (Friedrich, 197-8). Com relação às outras experiências que precederam a Revolução Americana existe uma divergência grande entre estes autores - costuma-se incluir Veneza, ao lado de duas outras cidades italianas (Florença e Gênova), o Império Germânico, Polônia, Genebra, Holanda e Inglaterra.

Pelo menos quatro destes exemplos teriam obedecido as quatro principais características do governo misto descrito por Políbio. A primeira característica seria a estabilidade. Muitos séculos teriam durado as Repúblicas de Esparta (que, fundada no século VIII, como todas as outras cidades gregas não pôde manter a sua independência frente ao domínio dos macedônios, a partir do século do final do século III a.C.), de Roma (que passou a ser um Império com Júlio César, na primeira metade do século I a.C.) e de Veneza (que perdeu definitivamente a sua independência após a derrotada para Napoleão, em 1797), enquanto que a monarquia constitucional inglesa duraria, de certo modo - isto é, depois de ter se adaptado às exigências da modernidade -, até hoje. A segunda característica seria o sistema de checks-and-balances. Em Esparta, este sistema 
teria sido introduzido após a conquista de Messênia, no século VIII a.C., quando os dois reis, o Conselho e a Assembléia do Povo (sob a liderança dos éforos) passaram a formar um sistema de pesos e contrapesos; em Roma, com a eliminação dos etruscos, no início do século $V$ a.C., este sistema começaria a tomar corpo lentamente, até que os cônsules, o Senado e a Assembléia do Povo (sob a liderança dos tribunos) passaram a ter funções predeterminadas específicas e a controlar-se mutuamente; em Veneza, este sistema teria sido introduzido entre os séculos XII e XIII com o doge, o Senado e o Grande Conselho; e, na Inglaterra, com a Revolução de 1640, quando a coroa e o Parlamento (dividido entre a Câmara dos Lordes e a dos Comuns) passariam a dividir e a controlar entre si as funções de governo. A terceira característica seria a proteção da esfera privada dos cidadãos para com os governantes. Em Esparta, Roma, Veneza e na Inglaterra os cidadãos tinham, segundo esta visão, a sua vida, a sua liberdade e a sua propriedade protegidas contra o arbítrio dos governantes - não havia restrições ao livre comércio ou monopólios, os processos obedeciam a procedimentos preestabelecidos, o direito a defesa era assegurado e a criação de impostos e a expropriação de bens não era arbitrária. Estas três características aproximariam Esparta, Roma, Veneza e a Inglaterra da República Americana. No entanto, uma quarta característica, comum às primeiras, as afastaria desta última: a divisão do poder entre os estados que compunham a sociedade. Em Esparta, a nobreza (os reis e os membros do Conselho) participariam separadamente do poder com o demos (membros da Assembléia); em Roma, os patrícios (cônsules e senadores), com a plebeus (membros da Assembléia do povo); em Veneza os patrícios (o doge e os membros do Grande conselho), com o povo (membros do Grande Conselho); na Inglaterra, o rei, a alta nobreza (representada na Câmara Alta) e a baixa nobreza e a burguesia (representada na Câmara Baixa) participariam separadamente do poder (Loewenstein, 1973, 255-72; Nippel, 1980, 131-6, 156-8).

Nesta dissertação procuraremos rejeitar a tese de que haveria uma linha contínua entre as doutrinas e experiências políticas do passado até a 
Revolução Americana, sustentando que houve uma ruptura com o passado no que diz respeito às concepções de liberdade e de igualdade. Os autores aos quais nos referimos no primeiro parágrafo foram levados a esta conclusão por não conseguirem discriminar as doutrinas e as experiências constitucionalistas das doutrinas e experiências republicanas clássicas - estas sim, preponderantes na Antigüidade greco-romana e no Renascimento italiano, além de estarem presentes nos debates inglês, na segunda metade do século XVII, e americano, no final do século seguinte, como depreendemos dos estudos pioneiros de Arendt, Baron, Gilbert, Stourzh, Wood e Pocock. No centro desta confusão, está a completa desconsideração, como afirma um grande conhecedor das formas de governo antigas, por aquilo que foi "o conceito central de Homero até o século XVIII": a virtude (Brunner, 48); a desconsideração de que ela marcou significativamente a vida política, social e econômica do mundo antigo, privilegiando a igualdade (no sentido antigo) dos cidadãos. Para sustentar a nossa tese, procuraremos demonstrar ao longo desta exposição: (a) que o governo misto formulado por Aristóteles, a mistura de democracia e oligarquia, que poderia perfeitamente ser entendido como uma doutrina precursora do constitucionalismo moderno, é por ele rejeitado veementemente em prol de um regime republicano democrático; (b) que no governo misto formulado por Políbio (o mesmo pode-se dizer de Cícero) o sistema de pesos e contrapesos é parte integrante, mas não a parte determinante, das Repúblicas de Esparta e de Roma; (c) que a Itália do Renascimento não originou nenhuma doutrina constitucional, sendo, pelo contrário, um dos principais focos de difusão do republicanismo - no século XV, com Leonardo Bruni, Trapezuntios e Poggio, e, no século XVI, com Guicciardini, Cavalcanti, Sabellico, Garimberto, Memmo, Nores, Caimo, Giannotti, Contarini e Paruta, cujas concepções de governo misto não podem ser entendidas como um sistema de pesos e contrapesos com o objetivo de garantir as liberdades individuais, e sim como parte de um regime republicano; (d) que, entre as experiências citadas do passado, que teriam realizado o ideal de liberdade individual, Esparta e Roma foram, na verdade, repúblicas, enquanto que 
nenhuma das principais experiências da Itália renascentista preencheram as características centrais do constitucionalismo antigo, descritas no último parágrafo (Florença gerou formas de governo popular extremamente instáveis e Veneza, embora reivindicasse que a sua estabilidade era devida a um governo misto, foi, na verdade, uma oligarquia); (e) que as primeiras doutrinas e a primeira experiência constitucionais, precursoras da República Americana, nasceram na Inglaterra, durante os séculos XVI e XVII e com o término da Revolução de 1640, respectivamente; (f) e, finalmente, que, ainda assim, o constitucionalismo dividiu forças, por um longo período, com o republicanismo clássico, principalmente na Inglaterra da segunda metade do século XVII, com James Harrington erroneamente interpretado como um constitucionalista, como atestam as afirmações de Sabine ("os elementos que constituem a república harringtoniana são típicos de um governo liberal" (469)), ou de Matteucci (com Harrington "passamos da tradicional teoria do governo misto à moderna teoria dos contrapesos ou do equilíbrio entre os diversos órgãos institucionais, cada qual investido de determinadas funções", que dá sustentação ao "governo constitucional moderno" $(1970,355))$ - e na América do final do século XVIII, particularmente com os Anti-Federalistas.

No Brasil, o interesse pelas doutrinas e experiências republicanas é bem recente.[PL1] Publicado há poucos meses, contamos hoje com uma série de artigos sobre o republicanismo, cujo ponto de partida é um certo desconforto quanto ao debate político atual, proveniente da aceitação natural da primazia da economia sobre a política, a ponto de descaracterizá-la, transformando-a em um meio daquela. Tal primazia teria levado ao abandono progressivo da idéia do público e do bem comum, isto é, da essência mesma da política, reduzindo-a a um arranjo institucional com o intuito de possibilitar uma competição pacífica entre 
os diversos grupos que formam a sociedade em defesa de seus interesses privados. Este desconforto levou Cícero Araújo, Marcelo Gantus Jasmin, Newton Bignotto, Renato Janine Ribeiro e Sérgio Cardoso, a "pensar a república", retomando os autores clássicos que se filiaram a este ideal. Este mesmo motivo me levou a tratar deste tema. 


\section{O IDEAL REPUBLICANO: ARISTÓTELES}

Para Aristóteles, o pai do republicanismo clássico, a comunidade política (koinonia politike), a forma de governo ideal, a república (politie), não é natural. A sua constituição depende de um enorme esforço para não ser contaminada com outras formas de relacionamento humano, naturais no mundo antigo. Da comunidade política, de sua forma de governo, devem estar ausentes não somente as relações que caracterizam as comunidades familiares (koinonia oikonomike), mas também o relacionamento que caracteriza as comunidades portuárias da Antigüidade, fundadas no intuito de exercer atividades lucrativas (koinonia chrematistike). O modo de vida político (bios politikos), o tipo de relacionamento humano que deve marcar a comunidade política, não pode se confundir nem com o modo de vida familiar (bios oikonomikos) nem com o modo de vida lucrativo (bios chrematistikos). A conclusão é de que, quando uma forma de governo se contamina pelas relações pré-políticas da família ou pelas relações extrapolíticas do porto - surgindo, como veremos abaixo, no primeiro caso, uma monarquia ou uma aristocracia, no segundo, uma tirania, uma oligarquia ou uma democracia - ela não dura, torna-se instável.

A condição sine qua non de uma comunidade política é a amizade (philia). Ela é uma virtude (arete) ou, como diz Aristóteles, mais precisamente, aquela que nasce do convívio entre virtuosos (Ética a Nicômano 1155 a 2-4; Ritter, 134-135; Tricot, 1979, 382). Entendida como a disposição (hexis) de subordinar o próprio bem ao bem dos outros, a amizade possui uma qualidade específica que a distingue das outras virtudes. Ela pressupõe um relacionamento de reciprocidade, isto é, um relacionamento que exige dos outros o mesmo comportamento - "os amigos desejam entre si altruisticamente o bem do outro" (EN 1156 b 7-11). Em outras palavras, a amizade pressupõe a igualdade 
(entendida como a homogeneidade de comportamento, de conduta) (EN $1158 \mathrm{~b}$ 27). Para tanto, ela impõe uma limitação numérica e geográfica à comunidade política; ela exige uma relação face a face entre seus membros, pois sozinho (falta de outros) não pode haver amizade, como também entre os muitos e desconhecidos (pelo excesso) (EN 1158 a 11-13). Esta qualidade específica, que distingue a amizade das outras virtudes, faz nascer um relacionamento duradouro em vista do bem comum, faz nascer aquilo que Aristóteles chama concórdia, harmonia (homonoia) entre os homens (EN 1155 a 23). Para ser justo, magnânimo ou liberal - ações que visam o bem do outro -, por exemplo, não é necessário que o beneficiário da ação também o seja, não é necessário esperar deste nem a retribuição nem mesmo a disposição para tal. Pelo contrário, o pressuposto da justiça, da magnanimidade ou da liberalidade é a desigualdade (entre virtuosos e não virtuosos). Estas, no entanto, não podem gerar uma comunidade política. Nas palavras de Aristóteles, a amizade é superior a todas as outras virtudes, tomadas individualmente, pelo mesmo motivo que a faz superior à justiça: porque entre amigos a justiça não é necessária, enquanto que a pura justiça sem amizade não é suficiente para manter a harmonia entre os homens (EN 1155 a 22; Ritter, 13; Tricot, 1989, 210). Esta afirmação se sustenta na distinção entre a comunidade familiar (eticamente heterogênea) e a comunidade política.

Toda comunidade visa um fim específico (EN 1160 a 8), mas é em função da comunidade política que todas as outras comunidades são organizadas. Estas formam a esfera pré-política da família, a esfera das necessidades, que se funda numa relação natural de desigualdade (portanto, legítima). O senhor (despotes) forma com seus escravos uma comunidade em vista da subsistência da família (Política 1252 a 31-32). O marido forma com sua mulher uma comunidade em vista da procriação (Pol. 1252 a 27) - sem a qual a perpetuação da espécie (eidos) não seria possível. E a comunidade entre pai e filhos visa assegurar a prosperidade destes (EN 1161 a 13). Todas estas finalidades suprem as necessidades prévias para que a comunidade política 
possa existir: a primeira, a comunidade despótica (koinonia despotike), libera o senhor do trabalho, Ihe dá o ócio (skhole) necessário para participar das atividades políticas; a comunidade marital (koinonia gamike) garante a contínua reposição dos membros da polis; e a última, a comunidade paternal (koinonia patrike), prepara os filhos para o convívio futuro entre os adultos. Cada uma destas comunidades tem um fim próprio, como dissemos, e estão fundadas numa relação natural entre desiguais (anisous). A comunidade despótica se caracteriza por uma relação de permanente sujeição em proveito senhor - pois livre (eleuthere) é aquele que não está para os outros mas para si mesmo, enquanto o escravo nada mais é que um instrumento animado (EN 1161 b 4); na comunidade marital, trata-se de uma relação entre livres (do jugo da necessidade, da escravidão, portanto) mas permanentemente desiguais - pois ao marido, chefe da família, cabe o governo de sua mulher para o seu próprio bem, sendo concedido a ela (naturalmente imatura) unicamente a autonomia nas tarefas domésticas que Ihe são próprias (EN 1160 b 33-35); finalmente, na comunidade paternal, a relação entre pai e filhos é entre livres e temporariamente desiguais (dura até sua maioridade), para o bem destes. Dentre as relações familiares, a única exceção é a comunidade entre irmãos, a única a propiciar uma relação natural entre iguais (EN, 1161 a 25), na qual cada um promove o bem dos outros e é reciprocamente retribuído.

As considerações deste último parágrafo - referentes às comunidades que formam a família, por um lado, e aos modos de vida que elas propiciam, por outro - determinam a classificação de três formas de governo (arche) e a sua durabilidade. A discórdia (stasis) surge, em primeiro lugar, quando a esfera pré-política do oikos, onde as relações de desigualdade são estáveis por que naturais, invade e determina a forma de governo, a sua constituição (politeia). Os regimes monárquico e aristocrático se espelham na comunidade familiar: o rei (basileus) e os aristocratas (aristol), por se destacarem pelas suas virtudes (a justiça, a magnanimidade, a liberalidade, etc.), governam permanentemente para o bem de todos os homens livres mas não emancipados, imaturos para 
reconhecer o seu próprio bem. A razão da instabilidade e da conseqüente revolução constitucional (metabole politeion), nos diz Aristóteles, é óbvia: uma forma de governo só se mantém quando aqueles que a desejam superam em número e em força aqueles que a rejeitam (Pol. 1309 b 16) - ou ainda, quanto maior é o número daqueles que se interessam pela sua manutenção e daqueles que dispõem dos meios necessários para sua proteção, tanto mais estável é a forma de governo. A monarquia e a aristocracia só se sustentariam se os livres aceitassem a sua dependência definitiva de outro para atingir o seu próprio bem, ao invés deles mesmos perseguirem tal desígnio. Diante do desejo de emancipação política dos livres e nativos e da recusa do rei ou dos aristocratas em conceder-lhes a cidadania - pois cidadão (polites), define o filósofo, é quem participa diretamente do governo, isto é, dos órgãos deliberativos e judiciais (Pol. 1275 b 19) -, a instabilidade e, conseqüentemente, a revolução, são inevitáveis. Uma forma de governo que satisfaça a exigência descrita acima de estabilidade, deverá espelhar-se na comunidade fraternal, exceção às comunidades familiares. A forma de governo político (politike arche) satisfaz esta primeira condição de estabilidade - a não contaminação pela esfera pré-política do oikos - à medida que permite a cada livre e nativo "governar e ser governado em rodízio" (Pol. 1252 a 16). Pois, como é impossível que todos governem ao mesmo tempo, este deve se dar através do rodízio nos cargos, que, por sua vez, são ocupados por um curto espaço de tempo (Pol. 1261 b 4) - o qual, no caso de Aristóteles, está sempre associado à prática do sorteio. Esta forma de governo partilha os mesmos pressupostos que a comunidade fraternal: ao governar (para o bem dos outros) e ser governado (ser beneficiado por esta ação), em rodízio, a reciprocidade, a igualdade, é preservada. O sistema de rodízio, portanto, permite transferir para a esfera política as relações de amizade, que se reproduzem naturalmente somente entre poucos.

Evidentemente, aquelas formas de governo não são instáveis por si sós, mas unicamente sob certas condições. No caso de afetarem os homens livres e nativos, como na Grécia da época de Aristóteles, elas jamais poderiam 
durar; não sendo o caso em outras situações - como é fora da Grécia, como foi durante o processo de formação das cidades gregas. O despotismo é a forma de governo típica dos povos bárbaros (em especial, os persas), em que os súditos não se reconhecem como livres, aceitando naturalmente sua sujeição à vontade do senhor. A monarquia é a mais antiga de todas as formas de governo: ela surgiu quando as famílias - que de todas as comunidades são as mais primitivas, quanto à sua origem e quanto ao seu fim - se associaram num vilarejo, em torno de um patriarca, seu chefe religioso, e esmoreceu há muito tempo (Pol. 1252 b 16-27). Já a aristocracia - que, com base em uma passagem famosa (Pol. VII, 10), alguns comentadores consideram, erroneamente, ser a forma de governo ideal para Aristóteles, aproximando-o, desta forma, a Platão das Leis (Schütrumpf, 57) - deve ser concebida dentro do núcleo histórico da tradição heróica, descrita na llíada e na Odisséia, que ainda nesta época eram os pilares da educação grega. A nobreza homérica é uma classe fechada, intensamente ciente dos seus privilégios, do seu domínio e dos seus costumes e modos de vida refinados. Apesar de existir um sentimento de humanidade para com as pessoas comuns - até mesmo para os mendigos! -, apesar de não haver uma orgulhosa e aguda separação entre os nobres e o povo, não se pode imaginar que eles não formassem uma classe privilegiada. Esta distinção, proveniente do tempo das grandes migrações das tribos gregas, quando as virtudes aristocráticas (não só a destreza guerreira, como também as virtudes unilaterais, pelas quais os poucos se distinguem dos muitos), que legitimavam a ascendência dos nobres sobre o restante dos homens livres, perderam o seu sentido à medida que a igualdade social e política, a partir do século $\mathrm{VI}$, passou a ser gradualmente o valor predominante - a ponto de, do século IV em diante, só podermos nos referir a uma aristocracia de maneira vaga e rudimentar (Jaeger, 29-33; Meier, 1979, 7 e 8).

Do mesmo modo que das relações familiares (marcadas pela dependência, fruto da imaturidade natural ou temporal), também das relações de proveito (marcadas pela desigualdade, fruto do interesse próprio) não pode 
nascer uma relação de amizade, pois entre desiguais não pode haver amizade. A discórdia surge, em segundo lugar, quando a esfera extrapolítica do porto, onde os relacionamentos movidos pelo egoísmo e pelo interesse próprio são naturais, invade e determina a polis. Este é o problema que mais afeta os gregos na época do estagirita: o espírito de facção (EN 1155 a 26). À medida que os livres e nativos se emancipavam dos grilhões da aristocracia guerreira, acirrava cada vez mais intensamente, no seio da comunidade, o conflito de interesses. Ao longo dos séculos VI e V, a cena política é tomada pela primeira vez, conforme vão obtendo a sua cidadania, pelos artesãos, operários especializados, pequenos e grandes comerciantes. Enquanto que num primeiro momento a fonte de instabilidade política se devia à transposição de princípios éticos mais adequados às relações familiares para a política; neste caso, a fonte da instabilidade está na transposição do interesse para a política, gerando a corrupção (kakia) do sentido de bem comum, o motivo pelo qual a comunidade política é constituída. Quando os magistrados são movidos pela desmedida, pelo prazer do ganho, diz Aristóteles, os homens livres se sublevam contra estes e contra a constituição que permitiu tal licenciosidade (Pol. 1302 b 6-9). Enquanto a monarquia e a aristocracia buscam (em vão, a partir do século VI a.C.) a sua sustentação na correlação com as modos de relacionamento natural que formam as três comunidades do oikos, as três outras formas de governo são instáveis por corromperem a natureza mesma destes relacionamentos comunais - nestas, o governo é exercido em proveito próprio (Pol. 1279 b 5-10). Assim, enquanto que a relação entre pai e filhos se funda na imaturidade natural dos filhos para se autogovernarem (esta é a condição necessária de sustentação do governo monárquico, onde os livres não estariam suficientemente emancipados da esfera pré-política para serem cidadãos), o tirano governa em proveito próprio sobre homens livres e que, contra a sua vontade, são impedidos de exercer a sua cidadania. Enquanto marido e mulher dividem naturalmente entre si as tarefas políticas, para um, e parte das atividades domésticas, para outra (esta divisão só poderia se estender para uma forma de governo, uma aristocracia estável, se as atividades básicas da 
administração doméstica fossem preenchidas pelos nativos livres, que, devido a sua imaturidade natural, abririam espontaneamente mão de sua cidadania para serem governados pelos mais qualificados eticamente), a oligarquia é o governo dos poucos (os ricos e livres) em proveito próprio e sobre os muitos (os pobres e livres), que são excluídos da cidadania pelo censo. Finalmente, enquanto na comunidade de irmãos (que não é constitutiva do oikos, pois não está preso a nenhum dos requisitos do reino da necessidade) a promoção altruística e recíproca do bem uns dos outros é natural, formando uma autêntica relação entre iguais (EN 1161 a 25-28); a democracia, cujo modelo melhor acabado é Atenas, é uma forma de governo que permite a cada um viver como quer (Pol. 1317 b 12), agir conforme o seu desejo (Pol. 1310 a 34). Ao modo de vida fraternal, solidário, que a comunidade política propicia, se opõe o modo de vida livre, proporcionado pela democracia. Ela é o governo da maioria (os pobres e livres) em proveito próprio sobre uma minoria (os ricos e livres). Ao excluírem os homens nativos e livres da cidadania para governarem em proveito próprio, tiranos, oligarcas e democratas tendem a se transformar em déspotas e os governados, em servos (oikol), em instrumentos para o bem dos outros.

Evidentemente, encontramos na Política uma série de expedientes - que se baseiam mais na astúcia do que na violência - usados para a conservação destes regimes corrompidos. Entre os artifícios mais usuais do tirano, são os mais freqüentes: eliminar as pessoas que se destaquem; impedir toda forma de reuniões; ter espiões entre seus subordinados; limitar a riqueza destes para que não possam arregimentar soldados mercenários; ocupar os seus súditos (com guerras, grandes obras, etc.) para que não tenham ócio; criar a aparência de que procura promover o bem comum e de que é um bom administrador, na alocação dos recursos públicos, despertar, portanto, a impressão de que suas ações são determinadas altruisticamente, e não em função do enriquecimento próprio e do luxo pessoal (Livro V, cap. 11). Também para a manutenção da oligarquia e da democracia são empregados alguns truques (Livro IV, cap. 13). Para afastar os pobres das decisões públicas, 
mantendo a aparência de igualdade política, somente aqueles que atingiram determinado censo são multados pelo não comparecimento nas assembléias deliberativas e pelo não preenchimento dos cargos judiciários, enquanto os pobres estão isentos de qualquer punição; e somente os primeiros são obrigados por juramento público a assumir as magistraturas, enquanto os últimos estão desobrigados a prestar tal juramento. Apesar destes expedientes astuciosos (somados à eventualidade do uso da força física pelos governantes), não podemos concluir que estes regimes sejam estáveis. Prova disto são as revoluções que estes regimes corruptos inevitavelmente sofrem. Na oligarquia, a revolução se dá quando o seu membro mais proeminente, aproveitando a revolta dos muitos oprimidos, assume a sua liderança, para, uma vez vitorioso, transformar-se em tirano (Pol. 1305 a 36-40). O egoísmo ilimitado do rico, que inicialmente molda o seu relacionamento com os desiguais (os pobres), volta-se contra os seus iguais (os ricos) - prova de que a igualdade política é necessária para a estabilidade política, mas não suficiente. Durante a tirania, que raramente dura mais que uma geração, os muitos acabam, com o tempo, se conscientizando das verdadeiras intenções do tirano e da sua opressão, retomando, com a expulsão ou morte do tirano, o regime democrático. Na democracia, os ricos fogem, para não serem oprimidos pelos pobres, e, no seu exílio, organizam-se para derrubar seu inimigo e instituir uma oligarquia (1304 b 31-1305 a 1). O que facilita esta reconquista é a constante divisão dos pobres (agora participando diretamente do governo) em diversas facções, bem ao sabor dos demagogos, que, para tirar proveito da sua posição, jogam primeiro os pobres contra os ricos e depois uma parte dos pobres contra outra. Estas revoluções, que não formam um processo contínuo e circular, estão sistematizadas no capítulo 41 da Constituição de Atenas em onze momentos da história desta cidade: a monarquia, do povoamento da Ática sob Ion até o reinado de Phylo; a oligarquia de Draco, o codificador das leis; a democracia de Sólon; a tirania de Psístrato; a democracia de Clístenes; a oligarquia do Areópago; o governo democrático "dos demagogos" Aristides e Ephialtes; a oligarquia dos 400; "novamente outra democracia"; a 
tirania dos 30 e a dos 10; e, finalmente, a democracia "que dura até hoje" (Ryffel, 145).

Para que a esfera política não seja contaminada pelas relações pré-políticas (típicas da família), a solução, como vimos, foi a de estender, através do rodízio, as relações de amizade - a única virtude verdadeiramente cívica para a comunidade dos chefes de família. A solução de Aristóteles, para que a polis não seja contaminada pelas relações extrapolíticas (típicas do porto), causa da discórdia e da instabilidade, encontramos no Livro IV, capítulo 11: a constituição de uma classe média (mesoi politeia - também designada politie). Antes, porém, de esclarecer como esta solução satisfaz o segundo requisito da estabilidade (e felicidade) política, devemos retomar algumas considerações da Ética a Nicômano. A virtude, entendida como a disposição de impor limites às nossas paixões (desprezo, inveja, ódio, amor, compaixão, desejo, etc.), é um meio (mesotes) entre dois extremos: o vício do excesso (hyperbole) e o vício da falta (elleipsis) (NE 1107 a 2). Evidentemente, esta regra não pode ser seguida à risca, como fica claro nestes três exemplos: a coragem (Livro III, cap. 9 e 12), a moderação (Livro III, cap. 13 e 14) e, principalmente, a liberalidade (Livro IV, cap. 1 a 3). Assim, a coragem (andreia) é um meio termo entre dois excessos: o excesso de coragem (o destemor) e o excesso de medo (a covardia). A moderação (sophrosyne) é um meio entre o excesso daquele que busca ilimitadamente o prazer (o licencioso) e a falta daquele que é insensível aos prazeres corporais - o que não existe na realidade. Na liberalidade (eleuteriotes), excesso e falta se unem num único hábito: liberalidade em dar é um meio termo entre o excesso na doação de riquezas (o desperdício) e a falta em dar (a ganância); e a liberalidade em receber é um meio termo entre o excesso na aquisição de riquezas (a ganância) e a falta na aquisição de riquezas (o desperdício). Portanto, o vício da falta de liberalidade consiste na falta em dar e no excesso em adquirir, isto é, na ganância (pleonexia); e o vício do excesso de liberalidade, no excesso em dar e na falta em adquirir, isto é, no desperdício, na 
não disponibilidade de riquezas para que se possa ser liberal (Schilling, 29-31 e 54-57).

A origem das revoluções, lemos, está na distribuição desigual das riquezas (Pol. 1266 a 38-39). Os ricos (os comerciantes), diz Aristóteles, cujo modo de vida determinante é a aquisição ilimitada de riquezas (bios chrematistikos), jamais aceitariam serem governados e quando governam tendem a assumir uma postura despótica; enquanto que os pobres (artesãos e assalariados livres), por terem que se dedicar exclusivamente à mera subsistência, tendem a seguir um modo de vida servil (bios oikonomikos). Este relacionamento, continua, é insustentável devido ao desprezo daqueles para com estes (impulso que faz com que os pobres sejam considerados instrumentos de sua vontade) e à inveja que os pobres nutrem dos ricos (impulso que os leva a se rebelarem ou a se sujeitarem, conforme a ocasião). Deste relacionamento entre inimigos não pode nascer uma comunidade política, pois, conclui, esta só é possível se fundada na amizade, que, por sua vez, só pode existir entre homens iguais, isto é, semelhantes (Pol. 1295 b 18-26). Para se chegar a esta homogeneidade na conduta ética, sem a qual a comunidade política não se manteria, são necessários dois passos prévios: a homogeneização da posse e a homogeneização da atividade produtiva. A república pressupõe uma larga redistribuição das posses, de maneira que a todos deve ser concedida uma posse média, que Ihes permita viver como agricultores (georgikon) (Pol. 1292 b 25). Estes dois passos iniciais visam alcançar a homogeneidade com relação à sua disposição quanto ao uso da riqueza: é melhor, afirma o estagirita, que a propriedade seja privada, pois esta é a garantia da sua independência; no entanto, os frutos da propriedade, a riqueza, deverá ser de uso comum, já que entre amigos tudo é comum (Pol. 1263 a 27-30). O uso desinteressado da riqueza é uma característica determinante da amizade - bem exemplificado numa frase desta época: "onde há um empréstimo em jogo não há amigo, pois se um homem é amigo ele não empresta, ele dá" (Finley, 1989, 70). Evidentemente, a redistribuição forçada das posses não adiantaria, pois ela não afeta em nada o 
desejo de aquisição, que, como antes, continuaria ilimitado (Pol. 1267 b 5-8). Pelo contrário: da parte dos ricos, certamente, haveria forte resistência à redistribuição e sua ganância seria reforçada por esta medida; da parte dos pobres, ela alimentaria o vício da aquisição, pois, se eles se contentam inicialmente com dois óbolos, passam a exigir com o tempo cada vez mais, até que sua exigência seja desmedida (Pol. 1267 b 1-3). Esse é o motivo pelo qual a expansão pelas conquistas, como forma de distribuição de riquezas (no caso, a dos povos conquistados), não pode ser aceita: o vício da aquisição é insaciável.

Estes dois passos decisivos - a equalização das posses e da atividade econômica, substituindo o comércio e a produção pela atividade agrária não lucrativa - devem ser dados pelos próprios cidadãos. Este é o apelo de Aristóteles aos ricos e virtuosos. Seu apelo não é de maneira alguma intransponível, porque é deles que depende o fim das revoluções (seu apelo, portanto, é também utilitário); é deles que depende, fundamentalmente, a eliminação de um excesso - a vida pautada pela aquisição ilimitada (bios chrematistikos) -, como também de uma falta - a vida daqueles que por não disporem de nenhuma propriedade são obrigados a se dedicarem exclusivamente à manutenção da mera vida, sem nenhum ócio, seguindo, portanto, uma vida próxima à do escravo (bios oikonomikos). O porto, que abriga aqueles que, movidos pela avidez, abandonaram a sua atividade agrária para se dedicarem ao comércio e aqueles que, não tendo posses, são obrigados a viver do trabalho braçal, deverá ceder lugar ao campo, assento dos iguais, de uma classe média de proprietários agrícolas abnegados. Para o primeiro passo - a redistribuição deve-se contar com a liberalidade dos ricos em dar. Para o segundo passo - a concentração na atividade agrícola - deve-se contar com a liberalidade dos ricos em receber. Isto significa a substituição da atividade da aquisição ilimitada (chrematistike) (para os ricos, um fim em si) pela administração doméstica em vista não do ganho, do lucro, mas, exclusivamente, da manutenção da mera vida, do ócio (oikonomike) e da vida virtuosa. Sendo uma atividade meio (um meio necessário para a construção da república), ela tem de ser limitada: só a troca 
será permitida, jamais o ganho, o lucro; e trocados poderão ser os excedentes produzidos para suprir as necessidades cotidianas, jamais as posses, que devem se manter para sempre inalteráveis (Priddat, 412). Estes passos iniciais, ao constituírem a base material da república, tornariam possível entre os livres e nativos construir uma comunidade de iguais. À distribuição igual das posses, se seguiria a distribuição igual do poder, para que um igual comportamento ético, a homogeneidade, possa ser esperada. Ou seja, a posse média e o rodízio dos cargos propiciariam a todos aquela relação altruísta de reciprocidade, administrando a riqueza, fruto da posse, de forma solidária. A esperança de Aristóteles é de que esta ação unilateral dos ricos inaugure um relacionamento fraternal, ou seja, o modo de vida político - nada difícil, já que os pobres só têm a ganhar nesta nova condição. A sua esperança está na criação de uma classe média universal, espinha dorsal da república, pelos ricos e virtuosos. Aristóteles esta é a razão implícita de sua crítica à Esparta - despreza a idéia da fundação (tão cara a Harrington), a idéia de que a república nasce necessariamente das mãos de um único legislador, que, como Licurgo, teria estabelecido, num único ato, tanto as condições materiais para o seu funcionamento (a lei agrária, que regulamentava a distribuição eqüitativa das terras, e a lei que impedia as atividades de comércio) quanto as condições formais (o conjunto de preceitos públicos, que estimulavam o bom convívio entre os cidadãos, e o ordenamento constitucional, que regulamentava as relações não só entre os governantes como também entre os governantes e os governados). Implícita nesta crítica está a sua convicção de que as leis, os preceitos e as ordens (a constituição) não tornam, por si sós, os homens virtuosos.

Diante do conflito social entre ricos e pobres que 0 aflige, a constituição sugerida por Aristóteles não é a da mistura entre oligarquia e democracia, e sim a do meio termo entre uma e outra. A melhor constituição, portanto, a única que está ao abrigo das revoluções, é aquela constituída exclusivamente pela classe média (Pol. 1296 a 7-9). Média pelas suas posses, pois a todos deve ser garantido a auto-suficiência e o ócio, necessário para 
participarem diretamente do governo; média, também, quanto aos seus impulsos, seus desejos. A constituição da classe média (mesoi politeia) significa constituição do meio termo (meson politeia): ela é média, uma vez que a propriedade e a atividade produtiva são uniformizadas e uma vez que o seu uso passa a ser regulado pelas relações de amizade - não havendo mais lugar para o desprezo e a inveja, não havendo mais espaço para o egoísmo, fonte principal da discórdia e da revolução. Seus cidadãos são proprietários rurais, cuja posse é entendida não como um bem em si, mas como um meio que lhes permite não só a independência necessária para que possam exercer os cargos públicos sempre que forem chamados em rodízio como também o exercício da virtude cívica.

Ao lado desta característica, soma-se outra. No capítulo 7 do Livro III, lemos que para que ela seja efetiva é imprescindível que todos os cidadãos disponham da virtude militar e dos meios para tanto. Como foi dito acima (Pol. 1309 b 16), para a sobrevivência de uma forma de governo, não basta que a grande maioria esteja interessada em mantê-la, mas que também tenha força para defendê-la - que é alcançada à medida que a propriedade fundiária possibilita a todos os cidadãos auto-suficiência não só econômica como também militar, à medida que ela dispõem a todos recursos próprios para se armarem. Mas isto não é tudo. A ameaça dos inimigos, internos e externos, da república faz brotar em seus cidadãos uma virtude cívica da maior importância para a sua estabilidade, a coragem - considerada por muitos republicanos a virtude cívica por excelência, a condição primeira para fazer parte da comunidade política (Arendt, 1981, 37) -, isto é, a disposição de sacrificar a própria vida em prol da comunidade. Mais do que o desprendimento do proveito próprio, morrer frente à ameaça de tiranos e déspotas - à qual as repúblicas estão constantemente sujeitas - é a maior prova de responsabilidade cívica. Sem dúvida alguma podemos dizer que esta virtude - a disposição ao auto-sacrifício pelos outros -, é o último grau a que chegaria a amizade, a disposição de preferir o bem dos outros ao bem próprio. A ênfase no cidadão armado, na necessidade dele se equipar por conta própria e se exercitar continuamente, leva em consideração não só a auto- 
suficiência e a defesa mais efetiva contra o inimigo - evidentemente quem luta sem temer pela própria vida leva vantagem sobre os outros -, mas também a sua qualidade ética. Embora não de uma forma tão explícita, encontramos aqui a idéia de que a ameaça externa é mais favorável para o modo de vida republicano e, conseqüentemente, para a estabilidade interna que a paz definitiva, à medida que é aquela e não esta que fomenta a virtude cívica. Sob este ponto de vista, trata-se aqui também de uma constituição média, não pela posse fundiária de seus integrantes, mas pela maneira como é estruturado o exército: a constituição dos hoplitas, os soldados da infantaria ligeira.

Concluindo: a república é uma comunidade onde os livres e nativos são verdadeiramente iguais. Na república reina a igualdade ética (todos têm a mesma conduta ética, todos estão dispostos a sacrificar o bem particular ao bem público), a igualdade política (todos participam diretamente do governo) e a igualdade sócio-econômica e militar (todos dispõem das mesmas posses, exercem a mesma atividade econômica e estão armados e treinados para lutar contra os seus inimigos internos e externos). Estas três instâncias da igualdade republicana são interdependentes, não podendo subsistir uma sem as outras: uma comunidade fundada na virtude cívica não pode conviver com a desigualdade política (típica das comunidades que se espelham no oikos) ou econômica (típica das comunidades portuárias); a igualdade política não pode sobreviver sem que todos partilhem a mesma disposição de se sacrificar pelos outros e as mesmas posses; e, finamente, só pode haver uma igualdade sócioeconômica e militar onde as duas outras estiverem presentes. Este tipo ideal de comunidade, a república de Aristóteles, exige a integração total de todos os livres e nativos, através da total homogeneização na infra-estrutura (na distribuição das posses), na superestrutura (na distribuição do poder político, ou seja, dos cargos e funções públicas) e no seu princípio ético - os três pilares de uma comunidade política estável e promotora da felicidade pública (eudaimonia). Ela não admite uma pluralidade em nenhuma destas três instâncias. Se ela não pode existir em Atenas, onde, apesar da igualdade política (propiciada pelo rodízio e pelo sorteio 
dos cargos públicos) e da igualdade econômica (propiciada pela participação direta dos pobres no governo), cada um podia desejar o que quisesse (o que acabou, com o tempo, minando tanto a primeira quanto a segunda); muito menos poderia ela existir na modernidade, onde as distribuições da riqueza e da atividade econômica são completamente heterogêneas, assim como os interesses e valores que determinam o comportamento dos membros desta comunidade, e o ônus da atividade política e militar não recai nos cidadãos, mas nos ombros de profissionais. Em poucas palavras, o modo de vida livre dos atenienses, que a sua democracia propicia, e dos modernos, que o constitucionalismo propicia, se opõe diametralmente ao bios politikos, que a politie propicia. Portanto, podemos definir a república de Aristóteles como uma comunidade onde a totalidade dos livres e nativos são iguais; mais especificamente, onde todos formam uma classe média agrária e armada, autônoma economicamente e militarmente, todos participam diretamente do governo, através do rodízio, e, finalmente, todos partilham o mesmo espírito cívico.

Diante deste quadro, ainda podemos associar o nome de Aristóteles ao republicanismo moderno, ou, mais especificamente, ao constitucionalismo? Ainda tendo como pano de fundo a questão social da sua época, o conflito entre pobres e ricos, Aristóteles discute uma outra alternativa: uma forma de governo fundada exclusivamente num arranjo institucional, prescindindo da virtude como seu eixo ordenador, cujo intuito seria preservar o modo de vida livre. Nos capítulos 8 e 9 do Livro IV, inicia-se a discussão do regime misto (que Aristóteles também chama politie), definido como uma mistura (mixis) de democracia (cujas principais instituições são o sorteio e o rodízio, para o preenchimento dos cargos, e o pagamento de um salário, para garantir que os pobres possam exercer as funções públicas independentemente dos seus recursos pessoais) e oligarquia (cujas principais instituições são a eleição e o censo, para limitar o preenchimento dos cargos públicos às famílias mais ricas) (Pol. 1293 b 33-34). Três são os modos de combinação e mistura das instituições (Pol. 1294 a 35-b 14): a combinação de uma multa (também uma instituição 
oligárquica) para os ricos que não quiserem preencher os ofícios judiciais, para os quais foram designados, com um salário para os pobres nomeados juizes; a mistura entre o alto censo e a ausência deste resultaria um censo mediano para a participação nas assembléias; e, finalmente, a mistura entre eleição e censo alto, de um lado, e o sorteio e a ausência de censo, de outro, resultaria na eleição sem censo para a ocupação dos cargos públicos. Evidentemente, estas regras de combinação e mistura institucionais, cujo propósito seria evitar a revolução à qual estão sujeitas as constituições simples que a formam (a democracia e a oligarquia), preservando o modo de vida livre, não podem ser compostas aleatoriamente. Temos, na verdade, dois critérios irreconciliáveis: pelo primeiro, a cidadania se estende até formar uma maioria entre os nativos, deixando de lado uma parte que por ser minoria e por ser a mais pobre, não teria força para derrubar esta constituição; pelo segundo, a cidadania é estendida até mesmo aos mais pobres, para que não haja exclusão. Assim, a qualificação de um censo mediano para a participação na assembléia não pode ser combinada com o pagamento de um salário aos pobres para que exerçam a sua nomeação como juizes. É tarefa dos legisladores buscar a combinação e mistura institucional mais apropriada.

O propósito do regime misto é conseguir através deste arranjo institucional um equilíbrio de interesses entre as facções que compõem a cidade. Havendo participação tanto dos ricos como dos pobres (ou boa parte destes) no governo, haveria um equilíbrio de poder entre as classes conflitantes. Isto evitaria que uma classe governasse sobre a outra em proveito próprio, obrigando cada uma das partes a ceder em suas intenções egoístas; a discórdia seria minimizada pelo compromisso entre as partes - uma conclusão que aproximaria muito Aristóteles do constitucionalismo. A mesma discussão, referente a esta forma de governo e à estabilidade que ela propicia através de um equilíbrio de poder entre as classes conflitantes, continua nos capítulos 5 e 6 do Livro VI. A maneira mais eficaz, diz o estagirita, de preservar a oligarquia é aproximá-la da democracia, distinguindo dois censos: um menor, aumentando o acesso a funções públicas de 
menor importância, e outro maior, preservando os cargos mais importantes nas mãos dos mais ricos. Estende-se a cidadania para uma parte dos muitos com o fito de superar em número aqueles que ficarão excluídos da cidadania e que, por isso, estariam interessados na revolução (Pol. 1320 b 20-28). A democracia deve, para a sua preservação, evitar as confiscações dos ricos, apelo comum dos demagogos para obterem o apoio popular (Pol. 1320 a 4-5); como também, se não for possível impedir a extrema pobreza, causa da perversão desta forma de governo, propiciando a cada um o dinheiro suficiente para adquirir uma pequena quantidade de terra, deveria ser pago aos pobres um salário para que estes freqüentassem as assembléias estritamente indispensáveis (Pol. 1320 a 34-1320 b 3); as magistraturas seriam divididas entre as sorteadas, para que os pobres tivessem seu acesso garantido, e as que são preenchidas por eleição, para assegurar uma melhor administração (Pol. 1320 b 13-14). Certamente, a oligarquia e a democracia descritas no Livro VI não são puras, mas sim mistas.

Aristóteles não guarda nenhum entusiasmo às constituições mistas. Apesar da afirmação de que "quanto mais mista, tanto mais duradoura é a constituição" (Pol. 1297 a 6 e 1266 a 4) (passagem que influenciou os comentadores que procuraram fazer de Aristóteles um defensor do governo misto), o eixo na discussão do estagirita acerca do bom governo e, portanto, da estabilidade de uma forma de governo é a virtude, tema central da Ética a Nicômano e da Política. A razão pela qual a discussão do regime misto aparece de forma marginal em sua obra deve-se ao fato de que as instituições ainda estão sujeitas a agitações mesmo quando as facções que se opõem entre si, os ricos e os pobres, são iguais em força (Pol. 1304 b 2-3). O equilíbrio institucional entre as classes conflitantes é um perigo para a estabilidade da constituição, pois elas são levadas à luta pelo poder e não ao repouso (Ryffel, 165). A qualquer momento uma das partes em equilíbrio pode não mais querer esta constituição, pois é fato inquestionável que quando uns possuem riqueza em excesso e outros nada têm cai-se ou numa democracia ou numa oligarquia ilimitadas (Pol. 1296 a 1-2). Efetivamente, o que Aristóteles leva em conta, na definição da república, não é o 
equilíbrio entre as facções, mas a sua eliminação. (A distância que o separa dos constitucionalistas pode ser medida pela afirmação de $O$ Federalista, $N^{\circ} 10$, que a uniformidade de interesses, paixões e propriedade é impraticável, e que os relacionamentos de animosidade recíprocos são benéficos, uma vez canalizados por meio de instituições apropriadas, para a estabilidade política). O regime misto cumpre a primeira condição de estabilidade política - a não contaminação da esfera pública pelas relações pré-políticas; contudo, por tolerar a sua invasão pelas relações extrapolíticas, geradoras da desigualdade econômica, o próprio equilíbrio político acaba se comprometendo. Por não se assentar nos três pilares da igualdade, a que aludimos acima, o constitucionalismo, entendido como governo misto, pode ser definido como um governo de homens livres, mas dificilmente seria um governo de iguais.

Uma última consideração deve ser feita - e que terá uma importância vital para a reabilitação de Aristóteles no século XV, com Leonardo Bruni. Resumidas na anedota sobre Tales (para quem as coisas do mundo são indignas de serem prezadas) e a escrava trácia (incapaz de se libertar delas para poder ver a verdade do filósofo), assim como na parábola da caverna, no início do Livro VII da República de Platão (onde aqueles que quiserem ver a luz, a verdade em si, terão que abandonar o mundo das sombras, das aparências da caverna), as concepções pré-socráticas, platônica e estóica, que cunharam a principal vertente clássica do modo de encarar a política, contrastam com a visão singular de Aristóteles, que irá influenciar decisivamente o debate sobre o republicanismo, ao longo dos séculos (Arendt, 1979, 155). Evidentemente, afirma o estagirita, existem seres cuja natureza é divina (NE, 1141 b 1). Sendo assim, a vida filosófica (bios theoretikos), a contemplação da verdade absoluta (ousia) - o ser enquanto ser -, é mais digna de ser seguida do que qualquer outra atividade. A contemplação (nous) do mundo supra-sensível, no entanto, ao exigir um desprendimento absoluto das coisas do mundo sensível, é uma capacidade divina, que não se pode exigir dos homens comuns (NE 1177 b 26-28). Em seus estudos políticos, por outro lado, Aristóteles enfatiza que o homem não é nem um 
animal nem um deus (Pol. 1253 a 28) e que o bem que deve ser almejado não é nem aquele que satisfaria todos os seres vivos (o que nos aproximaria dos animais) nem o maior de todos (o que nos aproximaria de deus), e sim o maior bem que o homem enquanto homem pode alcançar, a vida virtuosa (NE $1141 \mathrm{~b}$ 13-14). Para Aristóteles, trata-se de uma opção: os dois modos de vida são incompatíveis entre $\mathrm{si}$ - a vida contemplativa solitária das coisas divinas requer $\mathrm{o}$ afastamento da vida pública e vice-versa -, porém, dignos de serem vividos (como demonstra Bien em seus importantes estudos de 1981, 1982 e 1985). 


\section{ESPARTA E ROMA: AS REPÚBLICAS DE POLÍBIO}

Poderia, então, Políbio ser considerado 0 pai do constitucionalismo? Além do mais, seriam as Repúblicas de Esparta e de Roma, estudadas a fundo por ele, formas antigas de governo constitucional? O termo "constituição mista", embora jamais usado por Políbio, foi associado ao seu nome pelos seus sucessivos comentadores. Para ele, a melhor constituição (ariste politeia) é aquela composta pelas constituições simples, isto é, pela monarquia (basileia), pela aristocracia e pela democracia (História, Livro VI, 3.7). Sua qualidade específica é a durabilidade. Na monarquia o governante é aceito livremente pelos governados, isto é, esta aceitação é devida mais à concordância que ao temor e à violência (4.2); na aristocracia a aceitação advém da possibilidade dos governados elegerem os mais justos e sábios para o governo (4.3); finalmente, na democracia os governantes distinguem-se não por fazerem o que querem, mas por terem o hábito de honrar os deuses (como veremos adiante, a religião tem, para Políbio, uma importância vital para a vida cívica), obedecer aos pais e respeitar os mais velhos, com também por prevalecerem as decisões da maioria (4.5). Todas estas boas formas de governo se degeneram irrevogavelmente na forma de governo oposta: tirania, oligarquia e oclocracia, respectivamente. Nem mesmo as formas corruptas de governo são duráveis, sendo estas substituídas, respectivamente, pela aristocracia, pela democracia e pela monarquia. Esta seqüência forma o que Políbio chama ciclo das constituições (politeion anakyklosis). Em primeiro lugar, diz ele, nasce espontaneamente a forma de governo de um só, de onde surge a monarquia, fruto de um aperfeiçoamento da anterior (4.7); esta se transforma naturalmente (physei) em sua forma degenerada, a tirania, que é derrubada pela aristocracia (4.8); quando esta naturalmente se corrompe numa oligarquia, a multidão (pletos, plebs), não suportando as injustiças a ela cometidas, implanta a democracia (4.9); 
finalmente, devido às ações imoderadas e contrárias à lei desta multidão nasce, com o tempo, a oclocracia (4.10).

A sustentação da monarquia se deve não à violência, ao temor do mais forte, mas à aceitação pela multidão da sujeição a alguém que se sobressai na sua defesa. Assim como no reino animal os mais fortes são senhores dos mais fracos (5.8), é provável que na origem das cidades os homens vivessem assim, como animais em rebanho, seguindo por temor os mais fortes e valentes, organizados numa forma primitiva de governo de um só (5.9). Diante deste quadro, dois passos consecutivos moldaram a monarquia. Com o tempo surgiu na multidão a noção do dever, do que é certo e errado (6.7). Ela surgiu quando alguém, ao se destacar mais que todos na defesa de seus semelhantes, recebeu da multidão consideração e apreço pelo seu feito, enquanto que aquele que não agia desta maneira passou a ser desprezado e censurado por ela (6.8), despertando nesta o desejo de conspirar para destituí-lo (6.11). Também com o tempo, a multidão transferiu para seus descendentes a mesma confiança, pois acreditaram ser estes semelhantes a seus pais (7.2). Inicialmente, a monarquia manteve 0 apoio da multidão devido às medidas tomadas pelo rei - fortificação dos lugares mais apropriados com muralhas para assegurar a segurança externa de seus súditos e anexação de novos territórios para provê-los abundantemente dos meios necessários à vida (7.4) -, além do que, o rei vivia como os demais, não se distinguindo da maneira de se vestir, de se alimentar ou beber, não despertando, portanto, inveja ou difamação (7.5). No entanto, uma vez garantida a segurança e a subsistência dos súditos, seus sucessores hereditários entregaram-se desenfreadamente aos seus apetites, desviando os recursos necessários à vida confortável da multidão para o seu fausto e sua licenciosidade; e tornaram-se uma ameaça aos próprios súditos, à medida que estes, encolerizados por esta situação, não aceitaram mais a sujeição e conspiraram contra os que eles passaram a chamar tiranos (7.6-8).

Estas conspirações tomaram corpo quando a multidão descobriu em seu seio líderes que se destacaram como os mais ilustres, magnânimos e 
corajosos (8.1); e no lugar da tirania surgiu uma aristocracia, quando por gratidão por terem sido libertados da opressão e por estarem sujeitos a um governo orientado pelo interesse da comunidade, a multidão entregou a estes e a seus sucessores o seu destino (8.3). Também neste caso, assim que os filhos herdam seus cargos, acabaram se entregando à cupidez, ao luxo e à licenciosidade, transformando a aristocracia numa oligarquia (8.5), que despertou em pouco tempo na multidão novamente a mesma reação à tirania, provocando o seu fim (8.6).

Finalmente, depois de assassinados ou banidos o rei e os oligarcas e tendo ainda presente na memória as injustiças sofridas, a multidão, não se atrevendo em confiar o governo nem a um nem aos poucos que se destacam (9.2), assumiu ela mesma exclusivamente as rédeas do governo (9.3). Inicialmente, aqueles que foram obrigados a conviver com a violência e o arbítrio dos oligarcas ficaram satisfeitos com a nova situação e aprenderam a valorizar, mais do que tudo, a igualdade e a liberdade (9.4). Com o tempo, quando a democracia passou a ser conduzida pelos netos de seus fundadores, perdeu-se a lembrança dos tempos de opressão e a igualdade e liberdade foram desprezadas, ao mesmo tempo em que alguns - os mais ricos, sobretudo - procuraram a todo custo se sobrepujar à multidão (9.5). Não podendo dominar os outros por não se destacarem por suas qualidades, eles gastaram tudo o que possuíam procurando corrompê-la com favores de toda a espécie (9.6). Uma vez corrompida a multidão, uma vez que ela foi atraída pela promessa de vantagens, a democracia minguou (9.7), pois a multidão, agora disposta a usufruir a posse alheia para a sua subsistência, ao encontrar líderes ardilosos e eloqüentes que the serviram de guia, acabou por instaurar o império da violência (9.8). Fracionada em lutas internas, massacrando, exilando e saqueando uns aos outros, a multidão foi levada novamente, agora pelos demagogos, ao estágio da selvageria, até surgir alguém que, pela sua coragem, habilidade e apego à comunidade, restabeleça 0 convívio pacífico entre os seus membros (9.9). Este é o ciclo pelo qual passa cada constituição simples, o curso natural ao qual toda constituição pura está 
sujeita: sua degeneração, que provoca a revolução (metabole), instaurando uma outra boa forma de governo, até retornar ao ponto de partida (9.10).

Políbio, como teórico das revoluções constitucionais, mantém-se fiel à tradição do pensamento político grego, para a qual o destino de uma comunidade política depende principalmente de sua forma de governo - a causa predominante, diz ele, do sucesso e do fracasso referente aos principais acontecimentos é a constituição (2.9). No entanto, ao tomar Platão como contraponto a sua teoria (5.1), Políbio procura enfatizar que suas considerações, longe de serem especulações filosóficas, têm como base a observação histórica (5.2), pois é conhecendo aquilo que o passado tem a nos revelar que a razão poderá prever o que voltará a ocorrer (5.5). A história é seu mestre, é ela que possibilita, ao contrário das reflexões especulativas, um conhecimento útil (pragmatikos), um conhecimento que pode nos guiar para obtermos os resultados que desejamos. Ele entende a história como uma cadeia contínua de causas (aitial) e efeitos, o que lhe permite criar regras, as quais predizem que causas semelhantes produzem efeitos semelhantes (XII, 25b). A história é pragmática porque nos revela as fraquezas das constituições simples da antiga Grécia, ou seja, porque é que elas trazem em si a semente da corrupção (VI, 10.2); é através dela também - esta é preocupação principal de sua obra - que se compreenderá a durabilidade de Esparta, Creta, Cartago e, principalmente, de Roma, a razão de sua grandeza e de sua glória. A causa da instabilidade das formas de governo simples, a causa, portanto, das revoluções, é a concentração de um poder ilimitado e incontrolado nas mãos dos governantes; é ela que faz com que os governados, vítimas do arbítrio e do abuso, alternem sucessivamente - mas sem resultado - uma forma de governo por outra. Esta é a grande lição da história: toda forma de governo, uma vez que não lhe é imposta nenhum controle e limite, se corrompe.

Diante das ameaças de um inimigo externo e de sobrevivência, à qual estão sujeitas todas as comunidades de economia primitiva, a multidão elege aquele que se destaca pelas virtudes mais convenientes nesta situação: pela 
coragem, para melhor fazer frente ao inimigo e conquistar terras e riquezas alheias); pela frugalidade e modéstia, não se distinguindo dos seus governados em seus hábitos de vestir, se alimentar, habitar, etc.; e pela sua magnanimidade, ao se entregar a obras públicas que garantam aquilo que mais apraz à multidão, isto é, a segurança externa e uma vida materialmente confortável. Mas, uma vez que é concedido a ele e seus sucessores poderes sem nenhum limite e controle, a corrupção, o abuso de seus governados para satisfazer sua avidez, luxúria e concupiscência, torna-se inevitável. $\mathrm{O}$ mesmo acontece com a aristocracia. A multidão, tentando evitar as conseqüências desagradáveis do governo de um só, elege um grupo que se destaca pelas virtudes necessárias para a conduta dos negócios públicos, concedendo a eles e seus sucessores os mesmos poderes antes concedidos ao rei. Em pouco tempo, esta concessão cria nos governantes e em seus familiares um espírito de corpo, que os leva a assumir os mesmos vícios que o tirano deposto. Pelo mesmo motivo a democracia está fadada à corrupção. Querendo evitar as experiências anteriores, ao invés de eleger um ou alguns pelas suas qualidades a multidão passa a se autogovernar. Ela descobre e passa a valorizar a igualdade e a liberdade políticas; mas, inevitavelmente, pois não há limite ou controle sobre este autogoverno, deixa florescer em seu seio, instigada por demagogos, facções antagônicas que buscam através da força criar privilégios para si ou tirar proveito de seus concidadãos. A semente da corrupção - origem das revoluções constitucionais - está, portanto, no governo ilimitado e incontrolado. Esta é a conclusão de Políbio ao analisar o mundo heleno; e é a história de Esparta e de Roma que the mostrou como a corrupção foi evitada.

Evidentemente, outras cidades gregas, além de Esparta, também gozavam de um prestígio que Políbio não Ihes confere. Isto se deve ao fato deste prestígio estar ligado não às qualidades de suas constituições, mas a circunstâncias fortuitas. A mais importante destas circunstâncias foi a de surgir líderes excepcionais exatamente quando estas cidades mais necessitavam de sua presença. É justamente por ter que contar com a fortuna (tyche), ou melhor, por não poder dispor de líderes de excepcionais qualidades sempre que as 
circunstâncias exigirem, que estas cidades não podem ter o mesmo mérito que aquelas que graças à engenhosidade de suas instituições determinaram o seu destino (43.3). (É importante salientar que no conjunto de sua obra a noção de fortuna assume uma importância maior que a concepção inicial de um ciclo natural, ao qual todas as constituições estariam necessariamente expostas). Estes homens simplesmente adiaram o processo de corrosão a que já estavam sujeitas suas cidades. Seu estudo histórico, portanto, como Políbio enfatiza logo no início do Livro $\mathrm{VI}$, não trata do homem que por suas qualidades faz frente às reviravoltas da fortuna, pois estes são poucos e sua vida é breve, mas sim das constituições que adquiriram tais qualidades (2.6). Assim, Epaminondas e Pelópidas aproveitaram-se da política desastrosa adotada pelos lacedemônios e do ódio que Ihes nutria seus confederados para tirar proveito em sua luta contra Esparta, conferindo a Tebas a reputação de ser superior às outras cidades da Hélade (43.4). Do mesmo modo, Atenas conseguiu reverter temporariamente a sua sorte com Temístocles (44.2). Nesta cidade, freqüentemente assolada por conflitos sangrentos, a multidão assemelhava-se a um navio sem capitão: sob o perigo da tormenta, os marinheiros tornam-se sensatos e cumprem os seus deveres, obedecendo às ordens do timoneiro; quando, porém volta a calmaria nenhuma ordem é obedecida, de modo que enquanto uns procuram içar as velas para prosseguir viagem, outros procedem de maneira inversa, procurando ancorar o navio (44.3-6). Por isso, Atenas, depois de ter superado os mais terríveis perigos graças ao empenho da multidão e de seus líderes na luta contra o inimigo externo, sempre caia, em tempos de bonança, na mais profunda desgraça, quando a multidão, agora dividida em facções, entregava-se à luta fratricida pelo comando da cidade (44.8). Ao descrever tais agruras, Políbio critica os fautores da democracia por não levarem em conta que, uma vez sujeita a esta forma de governo, a cidade fatalmente se entregará "aos impulsos desenfreados de uma turba agressiva e obstinada", como em Atenas, ou "violenta e ambiciosa", como em Tebas (44.9). 
A proeminência alcançada por Esparta em toda a Hélade deve-se ao gênio de um único homem, Licurgo (10.1). Ele estava completamente ciente de que cada constituição simples traz dentro de si o germe da corrupção - na monarquia, quem governa transforma-se em tirano; na aristocracia, em oligarcas; na democracia, finalmente, a multidão torna-se selvagem e violenta (10.5). Com base nisto, Licurgo foi o primeiro a elaborar uma constituição que unia as características próprias e boas de cada constituição simples e a contrabalançá-las entre si, formando um equilíbrio entre as três partes, cujo objetivo era evitar que cada uma se degenerasse (10.6-7). Assim, o governo do rei não sucumbe à tirania porque seria contrabalançado pela multidão, pois estes também participam do governo; e a multidão, por seu turno, não ameaça ao rei, no intuito de instituir um governo democrático, porque teria o Conselho dos Anciões (gerousia) - a quem elegeu como os mais sábios - ao lado do mais fraco (10.8-9). Evidentemente, encontramos aqui uma simplificação exagerada na descrição do funcionamento desta constituição. A razão é apontada no início do Livro $\mathrm{VI}$, onde ele afirma que "as omissões que aparecerem ao longo da exposições globais iniciais, serão detalhadas mais adiante" (5.3) - promessa esta que nem sempre é cumprida satisfatoriamente, ao menos nos textos remanescentes, não só nesta como em outras exposições globais deste autor. Dois esclarecimentos deverão ser feitos, por este motivo, à sua exposição. Na verdade, não pode haver dúvida alguma de que o que a tradição prezou como a constituição de Licurgo foi, em vários aspectos, não o resultado de um ato único, e sim o de um longo desenvolvimento (Fritz, 1975, 101). Seu mérito seria - e este fato não poderia estar oculto de um historiador tão perspicaz quanto Políbio - o de ter criado, durante sua legislação, um equilíbrio muito mais perfeito entre aquelas três instâncias de governo, o que lhe rendeu o prestígio de evitar a má fortuna das revoluções. Este primeiro esclarecimento deve a sua importância à ênfase dada ao conhecimento advindo da história: Licurgo, ao contrário dos teóricos especulativos, teria se apoiado nas experiências institucionais de seu povo. Para Políbio, com vimos, o conhecimento só é prático quando tem como base os fatos 
históricos. Um segundo esclarecimento à exposição acima (VI, 10) se faz necessário, pois, para o leitor moderno, uma melhor compreensão do funcionamento da constituição espartana só é possível a partir de uma exposição mais detalhada - que certamente ou constava da parte de sua obra que foi perdida, ou era tão bem conhecida na sua época que a sua reprodução seria tediosa para os leitores.

À época da conquista da Lacedemônia pelos invasores dórios (século VIII), instituiu-se uma monarquia constituída por dois reis que dividiam o poder monárquico e se controlam entre si. O poder destes reis era, por sua vez, controlado pela Assembléia dos Guerreiros (apella). Com o final da Primeira Guerra Messênia, que resultou na anexação da Messênia, surge uma classe (dos descendentes daqueles que se distinguiram pelo seu valor combate), cujo poder passa a se expressar politicamente através de um Conselho (gerousia), formado pelos membros mais proeminentes e antigos desta aristocracia guerreira. Assim, muito anteriormente a Licurgo, já poderíamos falar, embora estes conceitos ainda não estavam presentes, de uma constituição mista, que possibilitava um balanço entre uma dupla monarquia, uma aristocracia eleita, representada pelo Conselho, e uma democracia, representada pela Assembléia de Guerreiros. Mais tarde, com a progressiva igualdade social e econômica, esta aristocracia dissolve-se num grupo único e homogêneo: os espartiatas. Outras reformas constitucionais advieram no final do século VII, após a Segunda Guerra Messênia, quando da sublevação dos conquistados, e no início do século VI, quando os espartanos empreenderam a reconquista de sua hegemonia no Peloponeso. Dentre estas inovações, destaca-se o Eforato, composto por cinco membros, provenientes das cinco aldeias originais (komai) que formavam a cidade. Os éforos, que até então eram os chefes religiosos destes assentamentos, passam a assumir tarefas específicas de governo, tornando-se mais um elemento de controle e equilíbrio, entre as outras instâncias de poder (Fritz, 1975, 101-3).

A constituição mista espartana, como era conhecida pela tradição greco-romana, pode ser resumida por estas quatro instituições que dividiam as 
funções de governo e controlavam-se entre si. A monarquia era hereditária, seguindo a ordem de primogenitura, e provinha de duas famílias dos Heráclidas. Caso houvesse, por qualquer razão, dúvidas quanto à sucessão, os cidadãos decidiam pelo voto quem deveria ser rei. Não havendo nenhum contratempo, seu reinado era vitalício. Os éforos podiam coagir, prender ou mesmo punir qualquer cidadão como também suspender o ofício de um rei, enviando-o a julgamento, embora não thes era permitido puni-lo (com multa, exílio ou mesmo a morte, conforme a gravidade de sua falta) sem a aprovação da Assembléia dos Guerreiros - ou Assembléia do Povo, a tradução mais freqüente de apella. Eles eram eleitos pelos cidadãos dos cinco assentamentos por um ano e prestavam contas dos seus atos, ao final do período, podendo ser julgados e punidos pelo mau uso de seus ofícios. A Assembléia do Povo não tinha iniciativa legislativa, mas decidia sobre guerra e paz, decidia sobre qualquer alteração das leis existentes e cabia a ela a decisão final de culpar ou absolver os reis e os éforos. O Conselho, eleito vitaliciamente entre os cidadãos, deliberava sobre os projetos de lei a serem apresentadas à Assembléia do Povo e decidia se elas deveriam ou não ser votadas. Ele possuía também funções jurídicas importantes e específicas.

Este resumo basta para termos uma idéia do funcionamento da constituição espartana - a divisão clara das funções de governo entre instâncias que se controlam mutuamente - e do seu objetivo. Evidentemente, um dos motivos pelo qual, desde o início, não houve facções em luta pela aquisição de maior proveito próprio, como em Atenas, deve ser buscado na necessidade de união entre os conquistadores para manterem a sujeição dos messênios, muito mais numerosos, e suas pretensões hegemônicas no Peloponeso. No entanto, o objetivo final da constituição lacedemônia não pode ser reduzido a esta necessidade; pois, independentemente de suas conquistas e de sua política externa, os espartanos estavam bem cientes dos infortúnios que necessariamente trazem as facções internas e da necessidade da criação de instituições que possam evitá-los. Os espartanos consideravam-se a si mesmos, e eram considerados por muitos outros gregos, como os mais livres entre os livres. Livre 
(eleuthere) - definição que coincide com a de Aristóteles e é aceita, com exceção de uns poucos filósofos, por todos - é todo aquele que, ao contrário do escravo, não está sujeito à vontade arbitrária de outro. Os reis podem ter o seu ofício a qualquer momento interrompido para serem julgados e, eventualmente, condenados pelos seus atos; além do mais não podem declarar guerra ou paz, prerrogativa da Assembléia. Também os éforos, ao terminarem sua magistratura anual, têm de prestar conta dos seus atos e dependem da Assembléia para punirem os cidadãos faltosos. O Conselho não pode impor seus projetos de lei sem a aprovação da Assembléia e uma vez aprovada a lei somente esta última poderá alterá-la. E esta, por sua vez, não pode fazer lei alguma, não pode pedir o julgamento dos reis e não pode deliberar sobre as estratégias de guerra ou de paz, prerrogativas do Conselho, dos éforos e dos reis, respectivamente. A característica central da sua constituição foi evitar o abuso do poder dos governantes. É por este motivo que os espartanos se consideravam, e muitos os consideravam, por exemplo, mais livres que os atenienses, já que estes viviam sob uma democracia, ou seja, estavam presos aos caprichos de uma assembléia popular e dos magistrados (sorteados de pouco em pouco tempo, que se substituíam por rodízio entre toda a população masculina), atividades governamentais sem freio algum - e que condenaram injustamente à morte os comandantes que venceram a Batalha de Arginusas, sem que ninguém viesse a prestar conta por este ato.

A tentativa de Políbio de buscar na história elementos para a sua teoria da melhor forma de governo, a única a ser considerada verdadeiramente boa e duradoura, tem em Roma o seu exemplo mais marcante. Como Esparta, esta cidade deve a sua fama à sua constituição mista - pois graças a ela, em menos de cinqüenta e três anos quase todo o mundo se sujeitou ao domínio dos romanos, um feito jamais igualado em tempos passados (2.3). Além do mais, sua perfeição, alcançada à época da Segunda Guerra Púnica (218-201), quando os romanos enfrentaram o gênio militar de Aníbal, foi fruto não de um único homem, mas de um contínuo aperfeiçoamento (11.1) - proveniente não da especulação, 
mas sim de muitas lutas e situações difíceis (10.14). Dito isto, Políbio descreve, agora mais detalhadamente, numa primeira parte, as funções dos cônsules, do Senado e da multidão - tão separadas entre si que mesmo para um cidadão romano seria impossível dizer se sua forma de governo era monárquica, aristocrática ou democrática, pois quem fixar sua atenção exclusivamente nos cônsules, no Senado (composto pelos patrícios) ou na multidão (formada pelos plebeus) a constituição romana parecerá exclusivamente monárquica, aristocrática ou democrática, respectivamente (11.11-12); e, numa segunda parte, como estes elementos controlam-se entre si.

Todos os magistrados, com exceção dos tribunos do povo, estão sujeitos às ordens dos cônsules, sempre que estes não estiverem ausentes de Roma, à frente de suas legiões. São eles que encaminham todos os embaixadores estrangeiros para o Senado. Todas as questões urgentes são levadas por eles ao Senado e os decretos aprovados por este corpo são por eles executados. Eles convocam todas as Assembléias do Povo, propõem diante delas novas leis e medidas administrativas e executam as decisões por ela aprovadas. Quanto aos preparativos de guerra e à condução das operações militares, seu poder é irrestrito para designar tribunos militares, para fazer quaisquer requisições aos aliados, para recrutar quem Ihes aprouver e para punir quem estiver sob o seu comando. Neste caso, quando estão se preparando para a guerra ou durante a guerra, os cônsules não dependem de nenhuma autorização para gastar os recursos públicos, podendo fazê-lo da maneira que lhes for mais conveniente. Sob este ponto de vista, o governo poderá ser caracterizado como monárquico (12.1-9). Já o Senado, em tempos de paz, controla as receitas e despesas do tesouro público, de modo que todos os magistrados dependem, para suas despesas, da autorização deste corpo. Crimes cometidos na Itália e que exigem uma investigação pública (como traição, conspiração, envenenamento e assassinato) são da sua alçada. Ele é o árbitro das disputas entre particulares ou entre comunidades, como também das reclamações de indenização e dos pedidos de proteção ou socorro. Cabe ao Senado a tarefa de mandar embaixadas 
fora da Itália com o objetivo de resolver pendências, apresentar sugestões, fazer exigências, aceitar submissão ou declarar guerra; cabe-lhe também a tarefa de recepcionar e responder às embaixadas vindas a Roma. Ninguém além do Senado exerce tais atividades, o que leva as pessoas que vêm a Roma, quando os cônsules estão ausentes, a considerá-la uma aristocracia (13.1-8). Diante disso, pergunta Políbio, que participação resta à multidão? Para ela, responde, está reservada a parte mais importante do governo. Como todos os cargos públicos são eletivos, é sua tarefa designar aqueles que são dignos de exercê-los. É ela, exclusivamente, que confere multas aos magistrados pelos seus atos. Somente ela pode autorizar a condenação de um cidadão à morte (exceto quando este esta servindo o exército). Cabe a ela aprovar ou rejeitar leis (embora não tenham a iniciativa legislativa). A deliberação sobre a guerra ou a paz é prerrogativa da multidão; com também a ratificação ou não de todos os tratados e alianças com outros povos. Visto sob esse ângulo, alguém poderia com razão dizer que esta forma de governo é democrática (14.1-12).

Em seguida Políbio descreve como se dá o equilíbrio entre as três partes. Em primeiro lugar, os cônsules são controlados pelo Senado e pela multidão. Como foi dito, os cônsules, durante uma campanha militar, parecem ter poderes irrestritos nos assuntos relacionados à sua atividade; mas, na verdade, dependem do beneplácito do Senado e da multidão. O Senado pode deliberadamente obstruir os seus planos militares, boicotando o envio de alimentos, roupas e do soldo que thes são devidos (nem todos que compunham as legiões romanas eram cidadãos auto-suficientes). Completado o seu mandato anual, é o Senado que decide se eles serão, individualmente ou não, mantidos no cargo ou substituídos por outros. O comandante militar vitorioso depende dos senadores para que possa celebrar sua vitória com pompa (a procissão chamada "triunfo" pelos romanos) ou pelo menos com uma magnificência menor, estando até mesmo sujeito a ter a sua vitória obscurecida, pois são eles que autorizam os recursos necessários a estes eventos. Por outro lado, os cônsules não são menos dependentes da multidão, que, como foi dito anteriormente, é quem ratifica ou 
rejeita os tratados de paz com os inimigos ou as alianças com povos vizinhos propostas pelo cônsul. Finalmente, o que é mais importante, no final do seu mandato anual os cônsules são obrigados a prestar conta à multidão. Por este motivo os cônsules têm de buscar a colaboração das outras duas partes (15.1$11)$.

O Senado, por sua vez, é controlado pela multidão. Os crimes por ele investigados só podem ser punidos, especialmente quando a pena é a morte, com a autorização da multidão (desde que, como foi dito, estes cidadãos não estão a serviço do exército). Um papel fundamental no controle do Senado pela multidão é atribuído aos tribunos da plebe, que, por sua vez, são obrigados a agir segundo a vontade da multidão e, ao contrário dela, dispõem da iniciativa legislativa. Assim, se um deles apresentar um projeto de lei que prive e reduza os privilégios, as honras públicas, os poderes ou até mesmo as propriedades do Senado, caberá unicamente à multidão aprová-lo ou rejeitá-lo; como também, se um deles interceder (vale a pena repetir que suas ações devem ter como motor a vontade popular), os senadores não só não poderão levar adiante suas decisões sobre qualquer assunto como também nem mesmo se reunir. Por todas estas razões o Senado deve temer a multidão e procurar atender seus desejos (16.1-5). Finalmente, a multidão é controlada pelo Senado e pelos cônsules. Como na Itália muitíssimas obras (edifícios, portos, parques, etc.) são construídos e mantidos pelos poderes públicos e os contratos de construção e manutenção são confeccionados pelo Senado, muitos homens de negócio e trabalhadores dependem dele para exercerem suas atividades e, por isso, farão de tudo para evitar qualquer confronto. Outro motivo desta atitude para com o Senado deve-se ao fato de que para as causas cíveis, públicas ou privadas, que envolvem grandes interesses, serão sempre nomeados juizes pertencentes a este corpo. Também é controlada a multidão pelos cônsules, pois ela está sujeita a eles enquanto durarem as expedições militares (17.1-9). Por este motivo, a multidão deve colaborar com o Senado e com os cônsules. 
Apesar do maior detalhamento, assim como no caso de Esparta, alguns esclarecimentos na descrição que Políbio faz da constituição mista romana são necessários para a sua melhor compreensão. O motivo de tais lacunas ou afirmações contraditórias é o mesmo que na descrição anterior - ou eram parte do que foi perdido de sua obra ou eram demasiadamente conhecidas de seus leitores, para que valessem a pena ser descritas. Quanto à decisão sobre os desembolsos do tesouro público, foi dito que esta é uma prerrogativa do Senado, exceção feita durante as campanhas militares, quando o cônsul assume inteiramente tal decisão. Mas, continua Políbio, aquele pode boicotar este, se recusando a enviar o dinheiro necessário ao sucesso da campanha. Neste caso, há, evidentemente, uma discrepância entre as funções de direito e de fato do Senado. Este poder, não previsto inicialmente na constituição, tornou-se imperativo à medida que as campanhas, cada vez mais distantes, longas e constantes - somada à necessidade de dividir o comando militar entre os dois cônsules, para que não houvesse uma concentração dos efetivos militares nas mãos de uma única pessoa -, obrigou os comandantes a estarem praticamente sempre ausentes de Roma e, portanto, a transferirem a outros a administração dos recursos necessários à suas campanhas. Esta discrepância vingou devido a uma necessidade prática, embora não tenha sido acompanhada de uma alteração constitucional. Em segundo lugar, foi dito também que o poder de declarar guerra ou paz é da Assembléia do Povo e que uma vez em guerra as negociações sobre tratados e alianças seriam da responsabilidade exclusiva dos cônsules. Mas também lemos que cabe ao Senado conduzir com as embaixadas estrangeiras as negociações sobre tratados de paz e alianças ou até mesmo declarar guerra. Estas ressalvas com relação ao Senado, também se devem a necessidades práticas. À medida que a condução das negociações externas tornam-se cada vez mais complexas e longas, é natural afastar tanto a multidão, para que as decisões possam ser bem fundadas (cabe lembrar que, na recepção das embaixadas, as assembléias deveriam ser convocadas pelo cônsul para num tempo curto resolver um problema específico); quanto o cônsul, já que um ano de 
mandato não é suficiente para manter uma política externa coerente. Por estes dois motivos tal atividade ficou concentrada nas mãos do Senado. Um terceiro esclarecimento deve-se à afirmação de Políbio de que o Senado pode prorrogar ou não o comando militar; mas, também é dito, cabe à multidão eleger aquele que acha digno de ocupar os cargos públicos. Na verdade, o termo desta prorrogação de comando era prorogatio imperii, que significa que o Senado deve levar à assembléia uma proposta (rogatio) de prorrogação de um ano do comando militar (imperium) para que a multidão vote. Senado e multidão dividem a função de controlar um poder que aumenta à medida que as campanhas tornam-se cada vez mais constantes, mais extensas e mais longas (Fritz, 1975, 161-167).

Outros esclarecimentos referem-se a outros controles, limitadores do poder das instâncias de governo, não descritos por Políbio, mas conhecidos pela tradição. Inicialmente, ficava a critério dos cônsules decidir, no caso de uma guerra, quem ficaria à frente do exército e quem ficaria à frente da administração civil - quando não havia consentimento, como ocorria freqüentemente, usava-se o procedimento do sorteio. Mais tarde este procedimento passou a ser prerrogativa do Senado, cabendo a ele decidir quem deveria assumir determinado posto. No entanto, para que os cônsules não ficassem demasiadamente influenciados pelo Senado, o que desequilibraria o poder a seu favor, foi adicionado, logo em seguida, outro procedimento, pelo qual um dos cônsules não concordando com a decisão do Senado e contando com o apoio do outro poderia recorrer à decisão final da multidão (Fritz, 1975, 167-8). Também não é dito por Políbio como o Senado controlava a Assembléia do Povo: os projetos de lei, propostos pelos cônsules ou pelos tribunos do povo (tribuni plebis) e aprovados pela multidão, só adquiriam validade legal depois de serem ratificados pela anuência (auctoritas) daquele corpo (Fritz, 1975, 133; Bleicken, 1989, 137-8; Arendt, 1979, 162-171). De acordo com a tradição, a plebe estabeleceu, por meio de rebeliões (recusando-se a votar ou a pegar em armas, por exemplo), o princípio da inviolabilidade do mandato dos tribunos (sacrosanctitas) - que passam a ser eleitos agora entre os líderes da própria plebe - associado ao direito destes 
intercederem em favor de qualquer plebeu que estivesse sendo ameaçado por um cônsul ou seu magistrado (ius auxilii), limitando o poder discricionário destes sobre a plebe (Fritz, 1975, 200-1; Bleicken, 1989, 86). Não menos importante, como fator de controle, é o fato de que não só todos os cargos públicos de maior importância eram colegiados - o que possibilitava a qualquer membro de um mesmo magistério interceder contra colegas de ofício orientados por projetos pessoais (intercessio) (Bleicken, 1989, 76-9) -, mas também só podiam ser preenchidos por eleição. Como nenhum magistrado recebia salário ou dispunha de algum aparato burocrático - esta é uma característica comum a todas as repúblicas -, somente aqueles que contavam com riqueza própria e pessoal de apoio próprio, em geral escravos ou servos, podiam exercer cargos públicos, isto é, os patrícios e aqueles plebeus que haviam alcançado sua auto-suficiência que na Roma republicana não representava a maioria de sua classe. Assim, os cônsules eram eleitos em sua maioria entre os nobres (patrici) (desde o século IV, os patrícios apresentavam, em sua lista de candidatos, um plebeu para uma das duas vagas) através de uma assembléia formada exclusivamente pelos membros do exército (comitia centuriata) (Bleicken, 1989, 96-9). Cabe notar que a reeleição era praticamente proibida. Quanto ao Senado, seus membros (todos vitalícios) são, em parte, nomeados pelo censor, em parte, eleitos pela Assembléia do Povo (comitia plebis) - da qual participam todos os plebeus entre aqueles que fazem parte de uma lista elaborada pelo mesmo censor. Este, além de determinar quem era digno de ser nomeado ou se candidatar a senador (optimus quisque) (mesmo os plebeus são aceitos, pois se levava em conta, principalmente, aqueles que haviam se destacado no exercício de alguma atividade pública), tinha também como função destituir aqueles que não haviam se mostrado dignos do seu ofício (Bleicken, 1989, 108-109; Büchner, 12).

Estas considerações, evidentemente, não visam preencher todas as lacunas da descrição que Políbio nos dá das constituições mistas de Esparta e de Roma, mas são suficientes para compreender sua teoria da constituição mista, isto é, de como o abuso do poder, origem das revoluções constitucionais, pode 
ser evitado através da divisão clara das funções de governo entre instâncias que se controlam mutuamente - e da importância que ela assume particularmente quando há uma desigualdade sócio-econômica, como em Roma, entre patrícios e plebeus. Mas isto não esgota o que Políbio tem a dizer das constituições de Esparta e Roma. Antes, porém, devemos desfazer duas interpretações correntes entre os comentadores modernos deste autor. Em primeiro lugar, as constituições de Esparta e Roma, da maneira como foram descritas até agora por Políbio, não podem se reduzir à doutrina constitucional da separação dos poderes entre o executivo, o legislativo e o judiciário. No caso de Esparta, o poder executivo, por exemplo, era dividido entre os reis e os éforos, sendo cada um dos sete autônomos entre si; o poder legislativo era dividido entre a Assembléia do Povo, da qual todo cidadão participava, o Conselho, eleito pelo povo entre o povo, e, em parte, os reis; enquanto que só estes últimos estavam privados do poder judicial. Já na Roma republicana do seu período mais maduro, os cônsules uniam em si os poderes executivo e judicial, além de possuírem a iniciativa legislativa. O Senado, devido à necessidade de sua autoridade (auctoritas), e a Assembléia do Povo, através dos seus tribunos, partilhavam também o poder legislativo. Todas as quatro instâncias partilham, de uma forma ou de outra, o poder judicial. Além do mais, um controle institucional efetivo, como de fato está previsto nestas duas constituições, é completamente ignorado nesta interpretação. Ao contrário da constituição mista, a doutrina da separação dos poderes não dá conta nem das limitações do poder nem dos controles sobre ele.

Em segundo lugar, a concepção de constituição mista - entendida como um arranjo institucional que garante a liberdade dos cidadãos ao evitar o uso abusivo do poder pelos governantes - não nos autoriza a atribuir a Políbio, como querem os comentadores contemporâneos da Introdução, a paternidade do constitucionalismo. Evidentemente, pelo que foi dito, tal aproximação não seria exagerada. Foi com este intuito que procurou-se associar Políbio ao estoicismo (em particular, Panaício, de quem teria sido discípulo). Segundo esta interpretação, Políbio teria renunciado o ideal republicano de virtude cívica 
(característica, como dissemos, do cidadão que coloca o bem comum acima dos interesses particulares e dos ressentimentos mútuos) e tomado o individualismo e o egoísmo como ponto de partida para a construção da melhor forma de governo. Em outras palavras, esta teria como função garantir aos cidadãos a estabilidade interna (o fim das revoluções) necessária para o gozo tranqüilo de suas atividades particulares. A mera vida tomaria o lugar da boa vida (Graeber, 52-8). O grande mérito de Políbio está em ter sido o primeiro a procurar comprovar que a grandeza e a glória de uma cidade (medidas pela sua duração, pela sua resistência às intempéries, tanto internas quanto externas, trazidas pela fortuna) assim como a liberdade que ela propicia seriam devidas ao limite e ao controle institucionais do poder (à divisão das funções de governo entre diferentes instâncias que se controlam mutuamente). E isto não é posto em dúvida por nenhum comentador. No entanto, o fato da constituição mista ter como função evitar toda forma de governo opressora não implica que sua função seja também a de permitir a livre fruição das atividades particulares. Como veremos, os valores aos quais se refere Políbio, longe de serem liberais, se enquadram dentro do universo republicano-aristotélico. Que o nosso autor influenciou decididamente os fundadores da República Americana, não há dúvida, como provou Chinard, em seu estudo pioneiro; no entanto, há de se fazer uma distinção, ignorada completamente por Políbio e clareada pela primeira vez por Harrington - e, posteriormente, por Montesquieu, ganhando rápida e ampla notoriedade - entre um governo republicano e um governo constitucional.

À descrição inicial do funcionamento da constituição lacedemônia (VI, 10), Políbio adiciona, mais adiante, alguns preceitos cívicos atribuídos a Licurgo, mas completamente alheios à estrutura da constituição mista; cujo papel, segundo ele, seria decisivo para a eliminação das revoluções. Como Aristóteles, Políbio julga ser a virtude cívica a condição necessária da estabilidade política (e, poderíamos acrescentar, do bom governo). Entretanto, a ausência de discussão sobre a necessidade de instituições públicas para a formação da personalidade cívica dos cidadãos, na obra do estagirita, faz a diferença entre estes dois 
autores: enquanto este está mais empenhado com a questão "O que é virtude?", a maior preocupação daquele é responder "Como tornar os cidadãos virtuosos?". Ao comparar Esparta e Creta, Políbio critica os escritores ilustres (Éforos, Xenofonte, Calístenes e Platão) que ignoraram as fraquezas da segunda, considerando-a tão digna de louvor e imitação, como a primeira (45.1). Entre os motivos que possibilitaram aos espartanos sobrepujar todos os povos de sua época, destacam-se, além da divisão eqüitativa dos bens (que em sua análise de Roma será desconsiderada como elemento determinante do sucesso de uma república), os seguintes preceitos: a alimentação frugal e coletiva, os exercícios militares durante toda a vida (48.3) e, finalmente, a proibição do comércio lucrativo e o controle de circulação do dinheiro (só a troca de mercadorias por outras mais escassas é permitida, não podendo ser usado dinheiro para tanto) (49.8). Os objetivos visados por Licurgo foram o de despertar, através disso, o relacionamento desinteressado entre os cidadãos e a coragem (48.4) - virtudes que possibilitaram aos lacedemônios liberdade e segurança por tanto tempo (48.5). Assim sendo, nenhum cidadão espartano podia ter uma posse de terras cultivadas maior que a dos outros (45.3); além do mais, a circulação de dinheiro era de tal modo controlada que os cidadãos eram desestimulados de qualquer desejo de acúmulo (45.4). Por outro lado, as leis cretenses não limitam em nada a aquisição de terras ou dinheiro, de modo que a competição pelo acúmulo de riquezas era tida entre os cidadãos como algo extremamente honroso (46.1-3). Foi por conta desta avidez exacerbada que os cretenses viram-se envolvidos constantemente em conflitos, banhos de sangue e guerras civis (46.9). É por este motivo que Creta não pode ser comparada à Esparta: extirpando a sede insaciável de riqueza entre seus cidadãos, Licurgo suprimiu também a discórdia e a guerra civil, o que permitiu que ela suplantasse todas as outras cidades da Hélade (46.8). O único descuido deste grande legislador foi não ter provido os lacedemônios de leis que limitassem o seu impulso expansionista: frugais e desinteressados em sua vida privada, eles tornaram-se ávidos pelos territórios vizinhos (48.6-8). Não dispondo de riquezas que sustentasse o seu 
expansionismo, Esparta sucumbiu devido à sua ambição externa desenfreada (49.6-10). (Este impulso expansionista, típico de Atenas e de Roma, entretanto, só exageradamente pode ser atribuído aos espartanos).

Estas considerações de Políbio ecoam o testemunho de Xenofonte, para quem Esparta era a cidade ideal para o homem livre: a obrigação de participarem continuamente, até a velhice, de exercícios militares (afim de que aguçassem a coragem diante do inimigo e o espírito patriótico); o afastamento dos adolescentes do convívio dos pais, para serem educados em instituições públicas (para que pudessem se desprender dos laços familiares e ficarem mais afetos ao interesse público); a freqüente promoção de refeições coletivas (syssiten), onde cada um traz a sua contribuição (para adquirirem o prazer da convivência entre si, além de hábitos frugais); a proibição de qualquer viagem que não fosse oficial (afim de não se contaminarem com os prazeres da vida faustosa e licenciosa dos estrangeiros); o controle da circulação das moedas (que além de serem grandes o suficiente para que qualquer um possa notar - e controlar - uma transação comercial, só têm validade em Esparta); e, principalmente, a exclusão dos cidadãos (os espartiatas) das atividades econômicas (um segundo preceito que, assim como o anterior, visa banir da comunidade a chrematistike) - à medida que a estes é devido unicamente a vigilância dos escravos (os hilotas, remanescentes do povo messênio), que apesar de trabalharem sua terra, eram propriedade pública, enquanto que o comércio e a indústria artesanal são atividades exclusivas dos periecos (em geral, estrangeiros livres), a quem é vedada a participação nos afazeres públicos (Fritz, 1948, 53-4). Objetivo destas regulamentações rígidas era formar cidadãos abnegados, desprendidos das fruições da vida privada - cidadãos dispostos até mesmo a sacrificar a própria vida em prol do interesse público, como Leônidas e seus trezentos espartanos diante do exército de Xerxes, o imperador persa.

Estranhamente, Políbio omite uma das principais instituições das repúblicas clássicas: estes preceitos jamais alcançariam o seu objetivo não fosse o que os gregos chamavam paideia, a educação pública formadora do caráter 
cívico dos cidadãos. Os poetas haviam sido, desde os tempos primitivos, arautos da virtude; e, dentre todos, Homero era tido como o grande educador dos gregos. Ao rememorar os grandes feitos do passado (míticos, em sua essência), o poeta educava, através da sua grandiloqüência, as gerações do presente a adotarem a mesma conduta ética. Nas elegias de Tirteu, cujos fragmentos disponíveis datam do século VII a.C., as cenas que animam a epopéia homérica são adaptadas à necessidade espartana. Assim, Tirteu recolheu não só no estilo lingüístico de seu mestre como também nas descrições dos combates e nos discursos da llíada o modelo para a exortação da qualidade cívica de seus cidadãos. Com isso, "o ideal homérico da arete heróica transforma-se no heroísmo do amor à pátria" (Jaeger, 82). Com outras palavras: a virtude cavaleiresca da epopéia homérica transformase, nas elegias de Tirteu, em virtude cívica. Além do mais, enquanto Homero se dirige aos membros restritos da antiga nobreza, Tirteu, por sua vez, se dirige a toda comunidade dos espartanos. Em sua exortação, o sacrifício de si próprio pela pátria é recompensado com o maior prêmio que se pode alcançar. Para aquele que cai entre os combatentes, "a sua dolorosa memória enche a cidade inteira e são honrados entre os homens o seu sepulcro e os seus filhos, e os filhos de seus filhos e toda a sua linhagem; a honra de seu nome não se extingue jamais e, mesmo que jaza no seio da terra, torna-se imortal"; para aquele que cumpre o seu dever para com a pátria, "honram-no jovens e anciãos, a vida oferece-lhe distinção e singularidade, ninguém se atreve a prejudicá-lo ou ofendêIo" (Jaeger, 84). A pedagogia do poeta se funda nos grandes exemplos humanos (muitas vezes míticos), oferecendo uma imagem do homem tal como ele deve ser e recompensando com o reconhecimento público aqueles que pautarem nela a sua conduta. Ao contrário do espírito político de Atenas, permeado pela individualidade, onde cada um faz o que quer, em Esparta, como diz Plutarco, citando Licurgo e Tirteu, "a educação estendia-se a todos; ninguém era livre [para fazer o que quisesse] nem podia viver a seu bel-prazer", em Esparta, continua, todos haviam se libertado "do culto do eu pessoal para pertencerem inteiramente à pátria" (Jaeger, 77). Ao não se referir à paideia, Políbio, curiosamente, deixa de 
considerar o que é para muitos a principal característica tanto da comunidade espartana como da romana (como atestam vários testemunhos da tradição).

Estas mesmas considerações valem igualmente para a Roma de seu tempo. Sua grandeza e sua glória - frutos de sua durabilidade, de sua resistência às reviravoltas da fortuna - são devidas também ao seu ethos republicano; e Políbio prova esta afirmação comparando-a a Cartago. Aparentemente, a constituição cartaginesa parece ter sido bem construída (51.1). Ela assemelha-se muito à espartana e à romana, pois os cartagineses têm dois reis, um Conselho de Anciãos de natureza aristocrática e o povo assume os assuntos que the dizem respeito (51.2). Trata-se, portanto, de uma constituição mista - e, presume-se, bem balanceada. Sua inferioridade com relação à Roma tem três motivos determinantes. Em primeiro lugar, os cartagineses combatem com mercenários estrangeiros, ao passo que as legiões romanas são compostas pelos próprios cidadãos, além dos habitantes de seus territórios aliados (52.4). A esta diferença soma-se outra - esta sim decisiva: aquele que está disposto ao mais alto sacrifício pela liberdade de seu povo supera facilmente quem luta unicamente pelo seu soldo; pois, mais do que o preparo militar, a coragem associada ao amor pela pátria (o objeto mais digno de amor, como dirá mais tarde um dos mais ilustres cidadãos de Roma, Cícero, refletindo o espírito de sua época) são os fatores predominantes na vitória (52.5-7). Esta disposição, longe de ser natural, continua Políbio, deve ser incutida nos cidadãos (52.10). Exemplo marcante de indução a esta disposição são os espetáculos cívicos referentes aos mortos ilustres. Sua descrição é tão viva e tão eloqüente (o que demonstra a sua importância para o autor) que vale a pena resumi-la num parágrafo.

Todo homem ilustre ao morrer é levado com pompa, em pé, até o Fórum, cortando os principais pontos da cidade, com o fito de engrossar o cortejo. Ali, com todo o povo a sua volta, um filho ou algum amigo próximo sobe aos Rostros (tribunas para os oradores, ornadas com proas de navios) e pronuncia um discurso cuidadosamente elaborado (laudatio funebris) aludindo às suas virtudes e aos seus grandes feitos. Em seguida, após o enterro, com a mesma 
pompa e cortejo, coloca-se sua imagem no lugar mais visível da casa, para que possa ser por todos reverenciada. Diante deste espetáculo, quem não seria tomado pela comoção? Além do mais, nos dias das festas religiosas públicas (organizadas e financiadas pela cidade) as imagens são ornadas com o maior esmero e os parentes que mais se assemelham ao defunto em estatura e compleição as levam para o funeral. Estes vestem uma toga com debrum cor de púrpura (togae praetextae), se o defunto era cônsul, toda de púrpura (togae purpureae), se ele era censor, ou bordada a ouro (togae pictae), se ele tivesse recebido as honras do triunfo ou alguma outra distinção pública. Tais homens são levados num carro precedido por fasces, machados e outras insígnias, às quais os personagens por eles encarnados tinham direito, de acordo com as funções públicas que exercera em vida. Chegando aos Rostros, eles sentavam-se em cadeiras de marfim enfileiradas. Não seria fácil imaginar um espetáculo mais nobilitante e edificante para um jovem que aspire à glória e à excelência. Quem não se sentiria estimulado pela visão das imagens de homens famosos pelas suas qualidades excepcionais, reunidos como se estivessem vivos e respirando? Poderia haver um espetáculo cívico mais belo que esse? (53.1-10). Assim, dois efeitos desejáveis são produzidos pela referência constante às virtudes e aos feitos nobres: imortaliza aqueles que se destacaram (54.2) (a maior das recompensas, para os republicanos) e estimula os jovens a suportar qualquer provação pelo bem da coletividade, na esperança de um dia também se imortalizarem pelos seus atos (54.3). Com efeito, estas afirmações foram corroboradas, diz Políbio, pelos fatos. Não poucos enfrentaram a morte certa seja para salvar os companheiros, seja para salvar a pátria, como aprendemos lendo a história de Roma (54.4). Alguns magistrados chegaram ao ponto de, no exercício de seus cargos, ordenar a execução de seus próprios filhos - uma demonstração de que seu interesse público estava acima dos laços naturais que os vinculam aos parentes mais queridos (54.5).

Um outro exemplo de dever cívico - fruto dos preceitos, dos espetáculos e da religião cívica - encontramos no último parágrafo do Livro VI. 
Após sua vitória sobre os romanos em Canas, Aníbal permitiu que os prisioneiros enviassem a Roma um grupo de representantes para negociar a sua liberdade mediante resgate. Eles escolheram dez de seus mais valorosos cidadãos, que antes de partirem juraram a Aníbal que regressariam. Em Roma, diante do Senado, os representantes suplicaram para que o resgate fosse pago, permitindo aos prisioneiros que voltassem ao convívio de seus familiares, pois aqueles homens mereciam a liberdade, já que não eram culpados de covardia (eles haviam sido deixados na retaguarda para proteger o acampamento, e, após a morte em combate dos soldados restantes, foram obrigados a render-se) nem tinham praticado nenhum ato indigno. Os romanos, que até este momento haviam sofrido duros reveses na guerra, diante do risco a que se expunha a própria pátria, tomaram a medida mais prudente em face desta situação. Ao perceberem que Aníbal pretendia com sua proposta obter recursos e aniquilar o espírito de combate dos romanos, mostrando-Ihes que, se derrotados, poderiam ser salvos, recusaram-se a pagar o resgate, apesar da compaixão inspirada pelos parentes dos prisioneiros. Tomada esta decisão, nove dos dez representantes, tomados pelas considerações patrióticas, decidiram espontaneamente voltar para morrer solidariamente junto de seus concidadãos e para cumprir a palavra dada. Isto fez com que Aníbal, inicialmente animado com sua vitória na batalha, se espantasse com a firmeza e a altivez dos seus inimigos.

O segundo motivo da superioridade de Roma frente a Cartago deve-se às suas leis rigorosas sobre a aquisição e a circulação de dinheiro (56.1). Políbio cita um exemplo extremado de abuso: em Cartago, devido à falta de tal controle, o uso tanto de dinheiro para aquisição de cargos públicos como de cargos públicos para a aquisição de dinheiro são permitidos - e, de fato, ocorrem com freqüência -, enquanto que em Roma tais ações são punidas com a morte (56.4). Finalmente, a superioridade dos romanos está também na maneira como sua religião é concebida (56.6). O que muitos condenam, é fundamental para a estabilidade da República Romana: o temor supersticioso dos deuses (56.7). Isto porque a melhor maneira de evitar a sujeição natural da multidão à inconstância 
das paixões desenfreadas e dos impulsos violentos é sujeitá-la ao temor do invisível (56.11). Foi por esta razão que os antigos introduziram premeditadamente na multidão noções religiosas sobre o bem e o medo do inferno (56.12). Assim, por exemplo, ao contrário dos cartagineses e de outros povos helenos, os magistrados e comissários romanos incumbidos de administrar uma soma considerável de dinheiro público possuem uma conduta correta unicamente por terem jurado, perante os deuses, cumprir com as obrigações de seu ofício (56.14). Temos aqui um caso exemplar de elaboração de uma religião cívica.

A constituição mista (definida como o arranjo institucional que evita poder ilimitado e incontrolado através da divisão das funções de governo entre instâncias que se controlam mutuamente) e os preceitos cívicos, os espetáculos cívicos e a religião cívica (que visam incutir nos cidadãos a disposição ao sacrifício pela pátria e o desprendimento da res privata) são, para Políbio, condições necessárias mas, quando tomadas isoladamente, insuficientes para a estabilidade política. Portanto - esta é a conclusão da segunda parte do Livro VI , apesar de Creta e, em particular, Cartago serem impecáveis quanto à sua engenharia institucional, falharam ao não incluir, ao lado de seus arranjos institucionais, preceitos cívicos. Do mesmo modo, podemos concluir da longa exposição da primeira parte, mesmo não sendo afirmado explicitamente por Políbio, que o regime republicano, fundado na virtude cívica de seus cidadãos, depende para a sua perpetuação de uma constituição mista (principalmente no caso de Roma, devido à divisão social e à dependência econômica advinda desta divisão). A república de Políbio, sua solução definitiva para as revoluções, é um regime misto - à virtude, o elemento determinante, é acrescida a mistura institucional de constituições simples. Retomando um dos seus conceitos centrais, somente ela é capaz de fazer frente às reviravoltas da fortuna. Além das considerações feitas acima sobre a necessidade dos preceitos cívicos, dos espetáculos cívicos e da religião cívica para a formação do caráter dos cidadãos, o que o distingue da república democrática de Aristóteles (democrática se 
levarmos em consideração que os cargos públicos são distribuídos a todos os cidadãos através do rodízio e do sorteio) é a sua ênfase nos mecanismos institucionais, proveniente de sua desconfiança dos governantes. Tendo a experiência histórica como base, Políbio acredita que não só os cargos públicos podem ser preenchidos por homens ambiciosos como também os governantes virtuosos podem com o tempo se corromper (em especial, Roma, onde a divisão social entre patrícios e plebeus tende a levar uns a excluir politicamente os outros). E o que o distingue do constitucionalismo liberal é a sua ênfase no dever cívico da multidão, a parte mais preocupante, pois a mais importante para a sustentação da república (56.11) - visto que sem um rígido controle sobre a vida dos cidadãos, que inviabilize totalmente (como em Esparta) ou em parte (como em Roma) a existência de uma esfera privada livre de qualquer regulamentação constitucional, nem mesmo o mais equilibrado arranjo institucional (como em Cartago) sobreviveria.

Ao compararmos as considerações de Aristóteles com as de Políbio sobre Esparta, somos levados às seguintes conclusões. O primeiro subestima demasiadamente o importante papel de determinadas instituições públicas, como os preceitos, os espetáculos, a religião e a paideia, para a constituição da personalidade cívica dos cidadãos. Já o segundo subestima a importância da igualdade política como condição prévia da virtude cívica. Por não contarem com um sistema de rodízio em sua constituição - provavelmente pela desconfiança de sua rival Atenas -, os espartanos foram levados a lançar mão da constituição mista. Ou melhor, foi justamente por não assumirem o rodízio dos cargos que eles foram obrigados a criar instrumentos de controle, uma vez que os principais cargos eram hereditários, como os dos reis, ou vitalícios, como os dos senadores - embora, a exceção dos reis, os cargos estavam abertos a todos e eram ocupados indiscriminadamente pelos livres e nativos. O que Políbio não considerou é que os magistrados são levados a se corromperem exatamente pela maneira como os cargos públicos são distribuídos - vitaliciamente no poder, reis, senadores ou, até mesmo, representantes do povo, por mais virtuosos que sejam 
tendem a se corromper. O comportamento ético homogêneo dos cidadãos, como bem notou Aristóteles, exige a igualdade política. Em Espartana, portanto, encontramos uma comunidade onde os livres e nativos foram iguais quanto à conduta cívica e aos bens materiais (os espartiatas, os pequenos agricultores armados, auto-suficientes economicamente e militarmente, e imbuídos dos deveres cívicos para com a pátria); porém ela foi deficiente quanto à igualdade política (pelo fato de não contarem com um sistema de rodízio dos cargos públicos, os ocupantes dos cargos públicos estavam tentados a abusar do poder). Esta foi, portanto, a única fraqueza da República Espartana.

Com relação a Roma, a comparação entre Aristóteles e Políbio, além de corroborar as conclusões a que chegamos no parágrafo acima, nos leva a uma última conclusão de vital importância acerca do bom funcionamento de uma república. Para tanto, vale a pena, antes, rever as considerações de Políbio acerca da durabilidade da República Romana, investigando detalhadamente as verdadeiras causas de sua queda - que se perpetuaram no Império, promovendo igualmente a sua destruição. Esta investigação é importante também pelo debate político que se travou com o fim da Idade Média: no Renascimento italiano, no início do século XV; na Revolução Inglesa, na metade do século XVII; e na Revolução Americana, no final do século XVIII. Nestes momentos decisivos do pensamento político procurou-se responder à questão se a queda da República Romana deveu-se a problemas intrínsecos do regime republicano - uma vez que este não seria capaz de lidar nem com os conflitos internos nem com a complexidade administrativa, como querem os seus detratores - ou se ela poderia ser evitada.

As causas que levaram à queda da República foram reconhecidas, pela primeira vez, já na controvérsia entre Cipião e Catão, quando da derrota de Aníbal. Para o primeiro, Cartago deveria ser preservada, pois se o último rival de Roma fosse removido, extinguiria com ele o amor pela pátria e a disposição ao auto-sacrifício, abrindo espaço para a corrupção - vitais para a sobrevivência da República, ambos são alimentados pela ameaça externa iminente. Para o 
segundo, Cartago deveria ser extinta, pois Roma não tinha mais força para retomar outra guerra prolongada com o seu velho inimigo. Evidentemente, com a sua total aniquilação (Terceira Guerra Púnica, em 146 a.C.), muitos dos preceitos e espetáculos cívicos romanos, sua religião cívica e sua paideia (centrada em grande parte na exortação à morte pela pátria) perderam a sua força. Aliado a este problema surge um outro, extremamente grave - do qual não encontramos nenhuma referência em Políbio. Ao longo das guerras púnicas e das conquistas, formou-se gradualmente um imenso proletariado na cidade de Roma, composto por antigos proprietários rurais que após quinze a vinte anos de serviço militar tinham abandonado definitivamente as suas posses - desabituados à vida no campo, eles vendiam a sua posse ao patriciado. Eleito tribuno em 134 a.C., Tibério Graco, ciente deste problema, propôs uma reforma agrária. Durante a conquista da Itália, boa parte das terras foi declarada pública (ager publicus) e emprestada às comunidades e indivíduos (principalmente às famílias de nobres que haviam se destacado pelos serviços prestados à República). Sua proposta consistia em retomar estas terras públicas e redistribuí-las em partes iguais aos proletários romanos, sem deixar de contemplar os atuais proprietários, de modo que todos os cidadãos pudessem ser auto-suficientes, e, portanto, politicamente independentes - condição prévia, segundo ele, da cidadania. Eleito tribuno por influência dos senadores, que, juntamente com suas famílias, tinham se beneficiado com esta situação, comprando as posses dos proprietários rurais que serviam no exército, Otávio veta esta proposta (fazendo uso de um dispositivo institucional, o intercessio, que possibilita a qualquer membro de um órgão colegiado interceder contra um colega de ofício que esteja orientando a sua conduta por interesses supostamente pessoais). Não conseguindo demover seu colega desta decisão, Tibério atropela este princípio convocando uma assembléia popular, sob a alegação de que aquele agira contra os interesses do povo. Aprovada a lei pela assembléia e protegido pela imunidade que seu cargo the propiciava, ele se tornou um empecilho tão grande aos senadores que acabou sendo por eles assassinado, sem julgamento prévio, juntamente com seus 
principais seguidores, sob a alegação de que ao violar tal princípio institucional tornara-se um inimigo da República. Estes eventos iniciaram a revolução que terminará, oitenta anos mais tarde, com a substituição do regime republicano pelo monárquico - que, por sua vez só adiará a queda final de Roma (Fritz, 1975, 255$62)$.

Apesar de aprovada, a reforma agrária não foi executada como prevista inicialmente, principalmente devido ao desinteresse do Senado. Além do mais, os italianos e os povos das províncias aliadas também exigiam que a cidadania romana thes fosse estendida, ameaçando abandonarem o serviço militar, os primeiros, e a ajuda militar, os segundos (a aliança de Roma com os povos vizinhos previa que ela ajudaria qualquer um que fosse atacado e que todos a ajudariam se ela fosse ameaçada). Isto levou o tribuno Caio Graco, irmão mais novo de Tibério, a propor uma série de projetos de lei, entre os quais, a extensão da cidadania aos italianos - a extensão aos povos vizinhos era extremamente problemática devido aos seus costumes, completamente estranhos aos romanos - e uma expansão mais agressiva da redistribuição de terras aos cidadãos. Estas propostas tiveram conseqüências drásticas. Elas provocaram uma reação contrária dos proletários romanos, que não aceitavam que os italianos tivessem os mesmos privilégios que lhes eram reservados pela lei de Tibério. Caio, para remediar as dificuldades de redistribuição das terras, impostas pelos senadores, elaborou dois projetos, prontamente aprovados: o subsídio do preço dos cereais consumidos na cidade e o pagamento de um soldo para os proletários permanecerem no exército. Finalmente, o conflito que se instalou entre os grandes latifundiários (cujos principais representantes passam a ser os próprios senadores) e os seguidores dos Gracos (que passam a formar a maioria do Tribunato) acabou por formar, após o assassinato de Caio, duas facções irreconciliáveis, dispostas a usar qualquer meio para derrotar a outra (Fritz, 1975, 264-72).

Resumidamente, foram estas as principais causas da queda da República. Em primeiro lugar, o desprezo dos senadores e dos tribunos 
(partidários da reforma agrária, buscavam, agora de forma demagógica, apoio popular para a sua causa) pelas instituições da República, pois a rivalidade era tanta que estavam dispostos a tudo para conseguirem o seu intento. Em segundo lugar, o fracasso no encaminhamento da reforma agrária fez com que os poderes institucionais se transferissem gradualmente a um órgão centralizador, uma vez que, para superar a crise de abastecimento de cereais que assolava a cidade, cada vez mais populosa, foi necessário desenvolver um gigantesco aparato burocrático tanto para orientar e controlar toda a produção de grãos e seu transporte, em todo Império, quanto para arrecadar impostos sobre os rendimentos de toda a população economicamente ativa do Império (o que obrigava o governo a obter informações precisas sobre todos os habitantes, suas atividades e suas posses, a cada ano - o census). Este novo poder, sob o qual não havia controle, tornou-se presa fácil dos cônsules e dos generais, visto que os senadores, antes glorificados pela população - os romanos alardeavam o desprendimento com que seus senadores matavam com as próprias mãos os inimigos públicos -, ao se tornarem meros defensores do grande latifúndio, haviam perdido totalmente o seu prestígio. Quando o exército, que era formado por cidadãos armados e proprietários rurais (portanto, autônomos economicamente e militarmente) passou a ser formado por soldados em tempo integral, pagos exclusivamente pelo erário público durante toda a sua vida, desenvolveu-se uma relação de clientelismo entre estes (facilmente manipulados devido à sua penúria econômica) e seus comandantes, cônsules e generais, cuja conseqüência foi o desprezo das duas partes pelas instituições republicanas. Aos comandantes militares não interessava a ordem constitucional, uma vez que, após a conquista do aparato burocrático, desfrutavam da lealdade incondicional de seus subordinados, concedendo-Ihes inúmeras vantagens; aos soldados também não interessava esta ordem, já que somente seus comandantes poderiam dirimir sua penúria. Evidentemente, entre estes quatro grupos, o responsável maior na queda da República foi o dos soldados, pois, como foi dito, nenhuma forma de governo pode subsistir se a parte maior da população (livre) 
não está interessada na sua preservação. A este fato associou-se outro: os cidadãos armados e proprietários rurais, espinha dorsal do republicanismo, além de reduzidos, estavam longe demais e desestimulados para poderem participar das assembléias populares, convocadas a todo instante pelos generais e cônsules, no intuito de manipular a multidão. Finalmente, este desprezo pelas instituições da República foi alimentado pelo esmorecimento do espírito cívico, uma vez que não só a ameaça externa (principal fonte de revitalização dos preceitos e espetáculos cívicos, além de sua paideia) deixou de existir com a aniquilação definitiva do seu último rival, como também a inviabilidade da reforma agrária impedia que houvesse, para a maior parte dos cidadãos, uma base material que garantiria o ócio necessário à participação política (Fritz, 1948, 63-9; 1975, 292-305).

Como conclusão, podemos dizer que a queda da República poderia ser evitada caso não fracassasse a reforma agrária dos irmãos Gracos, cujo propósito era a ampliação de uma classe média de proprietários agrícolas armados (a espinha dorsal da república, segundo Aristóteles, pois a origem de todas as revoluções está na distribuição desigual das riquezas (Pol. 1266 a 3839)). A reforma agrária (promotora da igualdade de posses e a auto-suficiência de todos os cidadãos) seria o passo inicial para a reforma política (onde estes pudessem participar diretamente do governo), uma vez que a sua constituição (concebida como um sistema de pesos e contrapesos para o controle e a limitação do poder) falhara em seu objetivo, formalizando politicamente uma desigualdade econômica e social. Somente assim, através da reforma agrária e política, os seus preceitos e espetáculos cívicos, a sua religião cívica e a sua paideia (cujo propósito era fomentar o espírito abnegado de seus cidadãos), poderiam retomar a força centrípeta que exerceram antes, quando a desigualdade econômica e política não eram tão gritantes. Esta foi a falha do teórico (e não do historiador) Políbio: ter subestimado - apesar de ser um profundo conhecedor de Esparta - a importância da redistribuição eqüitativa das terras, isto é, da igualdade econômica, para a sustentação do regime republicano, ou ainda, ter 
superestimado o papel do sistema de pesos e contrapesos de integrar politicamente os dois grupos que, devido a distribuição desigual das posses, jamais se reconciliariam, os patrícios e os plebeus - uma falha que não é levada em consideração pelo seu melhor comentador, Kurt von Fritz. Estas considerações comprovam as afirmações que fizemos, na conclusão do nosso capítulo anterior, de que a república não sobrevive sem que estejam presentes as três instâncias da igualdade republicana: a igualdade ética (onde todos têm a mesma conduta ética, todos estão predispostos a sacrificar o seu bem particular pelo bem público), que forma o seu fundamento; a igualdade política (onde todos participam diretamente do governo), que forma a sua superestrutura; e a igualdade sócio-econômica e militar (onde todos dispõem das mesmas posses e todos estão armados e treinados para lutar contra seus inimigos internos e externos), que forma a sua base material, a sua infra-estrutura. Ao fracassar a reforma sócio-econômica dos irmãos Gracos, a República Romana viu-se impossibilitada de constituir um governo verdadeiramente popular, ao mesmo tempo em que, devido a estes dois fatores, assistia passivamente o esmorecimento do espírito cívico de seus cidadãos. 


\section{FLORENÇA E VENEZA: LEONARDO BRUNI E OS TEÓRICOS RENASCENTISTAS DO GOVERNO MISTO}

Poderíamos, entretanto, localizar, na Itália do Renascimento, um centro privilegiado tanto de doutrinas constitucionais quanto de significativas experiências do constitucionalismo antigo? Para responder a esta questão, procuraremos, neste capítulo, relacionar as doutrinas políticas dos autores do Renascimento citados na Introdução com as circunstâncias políticas desta época. A Itália medieval difere significativamente do genuíno feudalismo da Europa ao norte dos Alpes. Ao invés de formarem uma hierarquia de senhores feudais, centrada na posse de largas propriedades agrícolas, na Itália do final do século XI grupos feudais começaram a se radicar definitivamente na cidade, transformandoa em centro político, e, juntamente com uma burguesia nascente (comerciantes e banqueiros), fizeram paulatinamente do campo uma simples zona de produção agrícola e de investimento. Esta diferença - a superposição da cidade ao campo -, no entanto, não nos autoriza a dizer que as cidades eram completamente autônomas, vivendo fora do mundo medieval, como querem alguns historiadores contemporâneos. Na verdade, estas recém-formadas cidades ainda estavam presas a duas forças antagônicas, mas centrípetas (conduzidas pelo ideal feudal da criação de um reino cristão universal), encabeçadas, de um lado, pelo Império Germânico - cujas pretensões eram respaldadas na doutrina do translatio imperii, segundo a qual, pelo desejo de Deus, o Império Romano teria sido transferido para os reis germânicos - e pela Igreja, de outro lado. Àquelas que não estavam diretamente controladas por uma destas forças, cabia unicamente a decisão ideológica ou pragmática - de tomarem o partido gibelino ou guelfo, respectivamente. A primeira tentativa de incorporação das cidades do regnum italicum (basicamente, a Lombardia) à ordem medieval deveu-se ao imperador germânico Frederico I, o Barbaroxa, que, no começo do século XII, organizou algumas expedições militares para anexar a parte italiana do seu Império, enfrentando o papa e seus aliados, as cidades unidas na Liga Lombarda, liderada 
pelos milaneses, que impuseram uma derrota à sua pretensão. A próxima tentativa de anexação do norte da Itália, empreendida por Frederico II na terceira e na quarta década do século XIII, apesar das conquistas iniciais, foi pouco a pouco suplantada pela Liga Lombarda, com apoio maciço da Igreja, e fracassou definitivamente com a morte súbita do imperador germânico, em 1250. No início do século XIV, Henrique de Luxemburgo, o herói de Dante, invade a Península, iniciando uma série de conquistas que culminaria, conforme sua intenção, em sua coroação a contragosto pelo papa, seu inimigo, como imperador do Sacro Império Romano-Germânico. A sua pretensão fracassou, uma vez que, como antes, os triunfos imperiais levaram os italianos do norte a se unirem contra o inimigo comum, agora sob a liderança florentina, visto que os milaneses, sob os Visconti, haviam, já na geração anterior, se aliado ao Império. Uma última tentativa foi feita pelo cauteloso imperador Luís da Baviera, inspirador e futuro protetor de Marsílio de Pádua, que, sabendo das dificuldades para empreender novamente campanhas de conquista, limitou-se, sem sucesso, em 1327, a insistir formalmente em seus direitos (Fédou, 91-8; Skinner, 1996, 25-8).

À tentativa dos imperadores germânicos somou-se a aspiração de anexação pela Santa Sé do centro e do norte da Itália. A partir do momento que Barbaroxa se recusou a sancionar a elevação do papa Alexandre III ao trono pontifício, o papa, apoiando com fundos as cidades que formavam a Liga, declarou-se seu inimigo - chegando a liderar o ataque ao invasor e, posteriormente, a negociar sua retirada. A mesma aliança foi restabelecida mais tarde, quando Gregório IX excomungou o imperador Frederico II, no início de sua invasão. Inocêncio IV continuou a política de seu sucessor, empregando tropas pontifícias contra o invasor - excomungando-o, mais uma vez - e retomou as negociações com as cidades toscanas a fim de reforçar sua cruzada contra o Império. (Foi neste momento que o termo "guelfo" começou a ser utilizado, nesta região, para designar os aliados do papa). Estas lutas sucessivas e bem sucedidas contra o inimigo, por sua vez, aguçaram no papado a sua aspiração imperialista. A partir de então, os papas procuraram não só estender seu leque de 
influência entre cidades, como também ampliar o seu domínio na esteira da liberação dos territórios anexados pelo Império. A liberação de Pádua das mãos do Império permitiu a Alexandre IV iniciar o processo de anexação das cidades lombardas, continuado com sucesso pelos seus sucessores, que, ao mesmo tempo, ampliaram a sua influência sobre as principais cidades toscanas Martinho IV firmou uma aliança com a Liga Guelfa, cedendo o direito às principais cidades toscanas de coletarem impostos papais a fim de reforçar a sua aliança, e Bonifácio VIII chegou até mesmo a tomar partido entre as facções internas de Florença, no intuito de controlar politicamente a cidade, sem obter sucesso. No centro, a Igreja conseguiu, também nesta mesma época, impor-se à Romanha, tradicional aliada do Império, anexando-a definitivamente, com as cobiçadas cidades de Perugia e Bologna, por Nicolau III. Assim, em meados do século XIII, uma grande parte do centro e do norte da Península estava sob o seu controle direto ou sob a sua influência. Em face de tal situação algumas destas cidades começaram a reagir. Uma década e meia após a morte de Frederico II, iniciou-se o levante contra as pretensões da Santa Sé exatamente na primeira cidade por ela libertada do jugo do Império, Pádua. Algumas cidades, particularmente as do norte, conseguiram desvencilhar-se da tutela da Igreja ao unirem-se ao imperador Henrique de Luxemburgo, no início do século XIV (Fédou, id.; Skinner, 1996, 3438). Durante esta longa luta entre imperadores e papas pela liderança do mundo cristão, as cidades ainda não anexadas foram tomando partido entre as duas facções levando em conta, evidentemente, uma maior autonomia; porém, uma autonomia absoluta, como querem alguns historiadores contemporâneos, fora do quadro medieval, onde a cidade era parte do reino universal cristão, era inconcebível neste momento.

No que diz respeito ao plano interno, podemos conceder, como querem alguns intérpretes da Introdução, que várias cidades contaram, na sua formação, com alguns rudimentos constitucionais. No final do século XI, iniciando com Pisa, muitas cidades começavam a adotar gradualmente a forma consular de governo, onde, para evitar o abuso do poder, o cônsul era trocado em sua função 
anualmente. Na segunda metade do século XII, o cônsul começava a ser suplantado pelo podestà - um funcionário assalariado, investido do poder supremo nas esferas administrativa e judicativa, mas que não pertencia à cidade que o contratava. Este procedimento objetivava implementar uma administração pública semelhante à sua cidade de origem, almejada pelos contratantes, e garantir a imparcialidade, isto é, garantir que nenhum vínculo ou lealdade local influenciasse o seu julgamento das partes conflitantes - a nobreza e a burguesia nascente. Ele era eleito pelo voto dos cidadãos por um período de seis meses ou um ano, ao final do qual prestava conta a dois conselhos - um mais aberto, podendo chegar a seiscentos membros dos vários grupos sociais que formavam a cidade (banqueiros, comerciantes e artesãos), mas de menor importância; outro mais fechado, com no máximo quarenta membros da classe social de maior destaque (os nobres), e de maior influência não só na indicação do candidato a podestà como também no seu julgamento. Este instrumento constitucional rudimentar de equilíbrio de poder entre os principais segmentos da cidade, que no final do século XII passa a ser adotada por quase todas as principais cidades do norte e algumas do centro da Península, começou a demonstrar a sua fraqueza já no século seguinte. O motivo deveu-se a sua incapacidade de assimilar os interesses da nova burguesia (gente nuova), que com o crescimento do comércio e da atividade financeira alcançavam uma posição de destaque, balanceando-os com os privilégios gozados pela nobreza urbana. A despeito de sua crescente riqueza, sem a qual jamais as cidades fariam frente aos inimigos externos, a nova classe continuava sem voz no principal conselho de suas cidades. O aumento do descontentamento fez com que ela buscasse desesperadamente 0 reconhecimento dos nobres. Isto levou os comerciantes e banqueiros a criarem um conselho próprio, presidido por um líder eleito diretamente, o capitano del popolo - o que significava um desafio direto ao governo do podestà, cuja indicação era influenciada normalmente pela nobreza, ciosa de seus privilégios políticos. Este desafio fez com que a inquietação inicial cedesse lugar à violência: impaciente, a nova classe apelou para o uso da força, procurando através desta 
restringir ou mesmo proibir a participação dos nobres no governo e, em casos extremos, bani-los da cidade. Diante da guerra civil que se instaurou, em fins do século XIII, na maior parte das cidades do centro e do norte, a solução, quase sem exceção, foi confiar a uma única pessoa um poder irrestrito, o signore. A signoria - o governo hereditário de uma única família -, no entanto, foi uma solução passageira, pois, se momentaneamente assegurava uma certa tranqüilidade interna, no plano externo os signori acabaram por acirrar ainda mais os conflitos entre as cidades. Portanto, à medida que estas experiências políticas não propiciavam estabilidade nem estabeleciam tradições, 0 desejo de pacificação pelo imperador ou pelo papa aumentava ainda mais. A tomada de partido entre gibelinos ou guelfos obedeceu a razões, senão ideológicas, ao menos práticas (Baron, 1993, 9; Colliva, 195-200; Skinner, 1996, 25-6 e 45-7).

Num ambiente inteiramente propício à irradiação de doutrinas autocráticas e à sujeição a um poder externo, Florença e Veneza foram as exceções. Mergulhada neste panorama geral, Florença reagirá de maneira singular, originando e propagando para toda a Itália uma alternativa ao dilema que tanto afligira as cidades, uma alternativa entre um autogoverno instável, incapaz de controlar o conflito entre as facções internas, e um poder absoluto, destituído de qualquer controle e limite. No século XIV, o ducado de Milão, sob o comando dos Visconti, que em meados do século anterior haviam assumido a signoria da cidade, emergiu como um poder dinâmico e unificador, superando a Lombardia e estendendo-se ao longo do vale do Pó. A partir da metade do século, sua expansão voltou-se para o centro da Península, em direção à Romanha papal e à Toscana guelfa. Razão deste sucesso foi a independência dos déspotas milaneses de qualquer laço com a tradição, ao passo que os imperadores e os papas dependiam da sua autoridade, mais que das armas, para estender tanto 0 seu domínio como as suas alianças. $O$ ducado despontou-se como o embrião de uma monarquia absoluta, nos moldes do que vinha ocorrendo ao norte dos Alpes, transformando os cidadãos das cidades conquistadas em súditos de uma vasta administração burocrática. No contexto ideológico que ainda vigorava entre os 
florentinos, estes viam os Visconti como vicários dos imperadores germânicos, líderes do partido gibelino na Península, e, como guelfos, viam-se na tarefa de seguidores e protetores da causa da Igreja. Ao longo desta metade de século, porém, pouco a pouco, foi ficando evidente aos florentinos que seus interesses não eram idênticos aos da Igreja. Após a conquista da Bologna, em 1350, tropas milanesas invadiram o território florentino e nem o papa nem outra cidade guelfa veio em sua ajuda. Além do mais, à medida que o papado reconquistava com sucesso o seu território romanho das mãos dos invasores, aumentava a suspeita de que, assim como o inimigo do norte, a Igreja não respeitaria, em sua ambição expansionista, as fronteiras da Toscana. Isto fez com que cada vez mais florentinos renegassem o credo guelfo. Nas décadas de 70 e de 80, Florença já havia desistido de sua política de dominação da Toscana e assumira a liderança de uma confederação com as principais cidades livres guelfas e gibelinas mais próximas (Pisa, Lucca e Siena, na Toscana; Perugia, na Umbria; e Bologna, na Romanha) contra as pretensões de dominação tanto do ducado quanto do papado (que com a sua transferência de Avignon para Roma, em 1377, iniciou uma luta pela reconquista de parte destas três regiões). Neste período, Milão passou a ser vista como o centro de uma monarquia absoluta moderna e o guelfismo caiu definitivamente em descrédito - com isto, a Igreja perdeu gradualmente a sua autoridade, sua principal força (Baron, 1993, 14-24; Tenenti, 12-16).

Neste momento, na segunda metade do século XIV, inicia-se uma experiência política única em toda a Itália: Florença passa a vivenciar um autogoverno popular. A cidadania é constituída pelos empresários, negociantes e artesãos, o popolo - tanto os nobres (grandi) quanto a maior parte dos assalariados estão excluídos. Os cargos públicos são preenchidos em duas fases distintas: a qualificação do candidato através do voto e o sorteio dos candidatos aos cargos vagos, seguindo o critério de rodízio. A qualificação efetua-se a cada cinco anos, quando dezesseis golfaloneiros de cada um dos dezesseis golfões (companhias armadas compostas exclusivamente por cidadãos armados) 
inscrevem os candidatos, que, por sua vez, são submetidos ao voto somente da parte da população inscrita nas diversas guildas (arti) - tanto nas arti maggiori (advogados, banqueiros, médicos, mercadores de tecidos, de especiarias e de couro, que formam os magnati) quanto nas arti minori (açougueiros, pedreiros, carpinteiros, vinhateiros, alfaiates, padeiros e outros artesãos menores). Ao final do escrutínio, os nomes dos candidatos que obtêm pelo menos dois terços dos votos são introduzidos indiscriminadamente em oito bolsas (borse), pelos accoppiatori. Sempre que um cargo se encontra vago, é feito um sorteio público, eliminando-se sucessivamente aqueles que ocuparam recentemente um posto, pois, para assegurar a rotatividade dos cargos, a reeleição só é permitida a cada dois ou três anos. A idéia é que o maior número de cidadãos qualificados (os membros das guildas que estão em dia com os impostos) pudesse participar diretamente da vida pública da cidade. Os cargos para as três magistraturas superiores, responsáveis pela administração da cidade e do território florentino, são preenchidos do seguinte modo: nove priori (seis representantes das guildas maiores, dois das menores e um gonfaloniere, chefe temporário da República e comandante do exército), que compõem a signoria, ocupam durante os dois meses de seu ofício o Palazzo della Signoria e recebem um modesto salário para cobrir suas despesas básicas; o Colégio dos Doze Anciãos (Dodici Buonomini) é renovado a cada três meses; e o Colégio dos Golfaloneiros (Sedici Gonfalonieri), formado por quatro representantes de cada um dos quatro bairros (cada bairro forma quatro golfões), eleitos a cada quatro meses. A signoria é assessorada pelos dois Colégios em suas decisões, que só se tornam válidas se forem aprovadas por maioria de dois terços, nas duas assembléias, o Conselho do Povo e o Conselho da Comuna, eleitas a cada quatro meses - o governo, portanto, é colegiado. Excepcionalmente, quando a ocasião exige, todos os florentinos maiores de quatorze anos são convocados para formar na Piazza della Signoria um Parlamento, para, com aprovação de dois terços dos presentes, criar de uma comissão de emergência (Balia), uma espécie de ditadura provisória, com uma duração preestabelecida e investida de plenos poderes para enfrentar a crise. 
Certamente, este sistema era muito mais complicado, e os melhores historiadores - sem falar da gente da época - têm muita dificuldade em descrevê-lo em minúcias (Rubinstein, 44-55; Tenenti, 17-19; Larivaille, 15-23; Hibbert, 17-25).

No plano externo, em 1390, inicia-se o confronto direto entre os florentinos e a monarquia dos Visconti, comandada pelo astuto Giangaleazzo. Enquanto este passou a propagar-se como o promotor da união e da paz numa Itália saturada pelas guerras fratricidas, Florença, nas palavras do Coluccio Salutati - chanceler do recém-criado governo popular e um dos mais proeminentes precursores do humanismo cívico -, proclamou-se defensora da liberdade e inimiga da tirania. Este ideal não levava em conta que grande parte dos seus aliados que formavam a Liga de Bologna - Pádua dos Carrara, Ferrara dos Este, Mantua dos Gonzaga, Bologna e tantas outras cidades menores - eram tiranias, mais preocupadas com a sua independência que com a liberdade de seus cidadãos. Apesar dos sucessos iniciais da Liga, Giangaleazzo, ao invés do confronto direto, foi minando a resistência dos inimigos, aliciando entre eles aliados para sua causa. Siena, Pisa (a única conexão de Florença com o mar), Mantua, Ferrara, Pádua, as pequenas tiranias da Romanha, Lucca, Perugia, Verona e Vicenza foram, uma após outra, atraídas pela promessa de proteção externa e de segurança interna da monarquia em formação - evidentemente, uma atração fomentada por grupos pró-milaneses, arregimentados e tutelados pelo duque, com dinheiro milanês. Isto, somado às conquistas milanesas do centro da Itália (Cortona, Chiusi, Spoleto, Assisi, Massa e Grosseto) e à política de neutralidade do papado e de Veneza (que acreditava estar fora da rota da ambição milanesa devido às boas relações comerciais com a Lombardia e à proteção natural de suas lagunas), fez com que os florentinos se isolassem ainda mais diante do inimigo. Desesperada, aquela que no passado liderou a aliança guelfa contra o Imperador, pediu ajuda a Wenceslau, pretendente germânico ao trono imperial, alegando ser Giangaleazzo traidor do Império. Uma atitude desastrosa, pois além das tropas germânicas não estarem preparadas para o confronto, o duque fazendo bom uso da propaganda, divulgou que a sua vitória foi 
um triunfo da nação italiana contra o invasor bárbaro, aliado dos florentinos. Apesar de boa parte das cidades ter se submetido ao domínio dos Visconti por pressentir que a sua sujeição era inevitável, a justificativa da missão desta nova força - a paz, através da unificação da nação, e a proteção contra o inimigo externo e contra a ambição da Igreja - ganhou mais credibilidade nas regiões sob o seu controle. Em 1402, graças a sua audaciosa diplomacia, fortalecendo as facções pró-milanesas, e a suas generosas doações, o duque finalmente atrai Bologna, a última aliada da cidade do Arno, para a sua causa. Somente um milagre faria o norte e o centro da Península escaparem do projeto de criação de uma monarquia sediada em Milão (Baron, 1993, 28-37).

Esta era a estratégia bem-sucedida de Giangaleazzo: preparar-se materialmente (cortando as alianças de seu inimigo) e moralmente (difundindo sua causa e aliciando entusiastas no terreno adversário) para uma conquista rápida e segura, evitando, assim, o desgaste militar de um confronto direto. Nesta época, o duque de Milão começou a ser prezado pelos propagandistas como o novo César. A esperança de um futuro de paz, advinda do statum italicum, estaria sendo sabotada pela resistência de Florença à unificação. Frente à ameaça iminente de invasão, os florentinos, ao invés de sucumbirem à propaganda, como tantos outros, redobraram suas forças morais e ideológicas para enfrentar o inimigo, uma vez esgotados todos os recursos materiais - incessantes e exaustivos esforços foram empregados pela diplomacia florentina para reaver as alianças antigas e demover tanto o papado quanto Veneza da sua imobilidade (Baron, 1993, 38-48; Pocock, 1975, 86-5). A conjugação de três fatos - a ameaça externa, o sentimento democrático dos florentinos (praticamente inexplorado por Baron) e o desenvolvimento do Humanismo (importado à cidade do Arno duas gerações atrás por artistas plásticos de renome, este movimento havia assumido uma dimensão sem igual nas diversas esferas da atividade humana) - fez com que, pela primeira vez na Itália, fosse buscado no ideal de imitação (imitatio) dos gregos e romanos antigos, uma base ideológica sólida para a crise política do momento. Entre tantos outros precursores, o florentino Leonardo Bruni destacou- 
se por esta empreitada. A obra do primeiro humanista cívico italiano compreende dois momentos: na primeira fase, ligada à crise externa, a sua preocupação é a de incutir o espírito cívico em seus concidadãos para fazer frente ao inimigo externo, uma monarquia absoluta cada vez mais aceita pelos italianos; enquanto que numa fase posterior, agora ligada à crise interna, a tônica de sua discussão é institucional, ou seja, o revigoramento, através deste mesmo espírito, da prática democrática de sua cidade, que começa a combalir nesta época.

No Elogio à Cidade de Florença (1400) e nos Diálogos (1401), descortina-se uma nova visão do passado: Bruni procura reabilitar o ideal da república, em particular, da virtude cívica, contra o ideal vigente do Império, que a partir de então estará sendo associado à corrupção, à tirania. O alcance desta revisão da história de Roma só pode ser avaliado se levarmos em consideração que um dos escritores mais respeitados da Itália e o maior orgulho de Florença, Dante, foi um tenaz defensor do ideal feudal da monarquia universal. No seu tratado da Monarquia (1310) é defendida a concessão total e irrestrita do poder ao imperador, para ele a única força unificadora capaz de vencer as facções que dividiam a Itália e de trazer a paz. Dante separa, de uma forma radical para a época, duas metas finais para o homem: uma é a salvação na vida por vir, que se alcançará pela filiação à Igreja; a outra é a felicidade nesta vida presente, que se atingirá unicamente sob a direção do império - concebido como um poder paralelo à Igreja e independente dela. Mas a sua obra de maior impacto, que ainda impregnava profundamente o espírito dos italianos da época particularmente, dos florentinos - era a Divina Comédia (1313). No seu Inferno os assassinos de César, Brutus e Cássio ("traidores do imperador humano"), estão postados no estômago de Lúcifer, lado a lado com Judas ("o abominado traidor do imperador divino"). Dante compartilhava o dogma medieval da Roma Aeterna, a idéia de que César foi o fundador de um império universal estático desejado por Deus, e que em sua época tinha sido transferido aos imperadores germânicos - 0 que fez com que qualquer tentativa de mudança fosse vista como uma traição. Tão grande é a tensão entre as duas concepções, que Bruni, neste mesmo 
tratado, irá justificar o julgamento de Dante dizendo que este não é o seu pensamento, que, portanto, trata-se de figuras poéticas, que não correspondem aos personagens históricos de Roma; e completa sua justificativa afirmando que Dante, sem dúvida alguma, estava bem ciente da importância histórica da ação virtuosa de Brutus (Baron, 1993, 48-9, 65 e 152; Skinner, 1996, 38-9).

Fruto do momento de crise (externa) pela qual atravessava Florença, esta nova visão do passado abre para o presente uma nova opção na discussão que se encadeará, ao retomar a história de Roma enfatizando a República ao invés do Império. Numa época em que o ideal do império - ideal difundido por mais de um século como parte do projeto divino - recrudescera, devido ao sentimento geral dos italianos de que um juiz supremo e soberano seria a única solução para as contínuas guerras entre os pequenos poderosos da Península, a afirmação de que a ruína de Roma foi devida à destruição da virtus romana pelo Império, foi revolucionária em seu efeito sobre o espírito da época. A crítica ao Império sob o ponto de vista republicano empreendida por Bruni, cujo significado histórico foi decisivo para o desenvolvimento do humanismo cívico italiano, foi fortalecida pela redescoberta de vários textos clássicos de história antiga, que somente a partir de meados do século XIV começaram a ter uma divulgação mais ampla - nas obras resgatadas de Tácito, trazidas para a cidade do Arno por Boccaccio, Bruni busca o testemunho de que, apesar dos grandes feitos pessoais, César e Augusto instituíram uma tirania, cuja conseqüência maior foi sufocar o fundamento mesmo da glória que Roma havia alcançado, o caráter do povo romano, causando a sua ruína (Baron, 1993, 54-61).

Após inverter o juízo corrente sobre César e seus sucessores, Leonardo Bruni, nestas duas obras, expõe uma outra tese subversiva. Durante toda a Idade Média, várias cidades italianas de projeção, assim como Florença, até então, se vangloriavam de ter sido fundadas por César. Conforme a lenda medieval, César perseguiu e derrotou Catilina e seu exército rebelde, acantonados nas colinas de Fiesole, fundando junto a este local Florença, uma fortificação contra os inimigos do Império; e César contaria sempre com o apoio 
irrestrito desta nova colônia. No século XIV, quando a cidade do Arno se despontou definitivamente entre as outras, as crônicas da época associavam sua glória ao fato dos florentinos descenderem dos colonos de César. Bruni, agora com acesso a fontes antigas (em particular, Salústio), buscou estabelecer as condições históricas exatas de sua existência: foram os vitoriosos veteranos de Sulla que colonizaram sua cidade, no início do primeiro século a.C. Ou seja, a fundação de Florença pelos romanos aconteceu antes que os efeitos viciosos do governo tirânico de César tivessem adulterado o caráter cívico do povo romano. Portanto, Bruni conclui, a missão política de Florença, herdeira da virtus da respublica romana, é ser o baluarte contra o império. Seu projeto é regenerar a moral cívica de seu povo, para que a ameaça enfrentada por Florença possa ser superada. Para tanto, celebra a ação de Brutus como um dos mais dignos exemplos de virtude; pois ao conspirar contra a tirania de César, ele colocou a salvação de sua pátria acima de sua própria salvação e de seus próprios filhos. $\mathrm{E}$ é justamente esta qualidade que o povo florentino, em cujas veias corre ainda o sangue dos colonos de Sulla, deve mais do que qualquer outra prezar: o autosacrifício pela pátria, pois não há amor comparável ao amor pela própria pátria. $O$ destino de um povo não está inexoravelmente preso à Providência (para aqueles que concebem o império dentro do quadro conceitual medieval) ou à necessità (para quem vê na monarquia absoluta nacional a única alternativa ao caos), mas sim à sua força moral. Assim como a ascensão de Roma deveu-se à virtude cívica de seus cidadãos e o seu declínio à imposição da tirania - por inibir e destruir justamente esta força dinâmica, ou seja, por corromper o povo, desviando o seu interesse da vida pública para a vida privada -, também Florença e as outras cidades italianas deverão cuidar das qualidades de seus cidadãos, único modo seguro de precaver-se contra o invasor (Baron, 1993, 61-4).

Esta revisão da história de Roma permitiu que se fizesse frente a uma outra ameaça à reabilitação do ideal republicano: o humanismo classicista, que, com base na reabilitação dos textos antigos, pregava o desprendimento das questões mundanas, em vista da superioridade da contemplação filosófica, da vita 
contemplativa, sobre a vita negotiosa (que engloba tanto a vida privada dos prazeres e do comércio quanto a vita activa). O maior representante desta ameaça foi florentino Petrarca, o pai do humanismo classicista e uma das maiores autoridades italianas nesta época. Para ele, como para toda a Idade Média, Cícero foi tido como um filósofo estóico, dedicado exclusivamente à contemplação solitária. Ávido por novas fontes clássicas, ele descobre, em 1345, na Catedral de Verona, as Cartas a Ático de Cícero, onde o autor aparece como um patriota republicano, inimigo do Império, e disposto a abandonar a vida retirada, à qual fora obrigado a levar em sua velhice, para enfrentar, arriscando a sua própria vida, a guerra civil que se instalou em Roma com o assassinato de César. Esta descoberta deixou-o profundamente consternado, pois, assim como Dante anteriormente, Petrarca havia, como tantos outros nesta época, depositado no imperador germânico, Carlos IV, toda a sua esperança de pacificação da Itália. Para ele, a conduta de Cícero representava uma afronta à tradição política medieval, à qual ainda estava preso, e à filosofia estóica, fundamento de seu humanismo classicista. $O$ império propiciaria a tranqüilidade pública necessária para que o filósofo pudesse se dedicar exclusivamente à leitura solitária das obras que tratam de coisas superiores, que não dizem respeito ao burburinho das coisas humanas. Petrarca, que optara por viver sob a proteção de uma tirania, garantia de paz e sossego para a sua atividade, reprova veementemente Cícero, em suas Cartas Familiares, por morrer "indignamente" pela causa republicana, ao invés de continuar a seguir a vida "digna" de um filósofo, distante das questões humanas, uma vida que só César e seus sucessores poderiam propiciar. Leonardo Bruni, na esteira de Aristóteles, reafirma a dignidade da vita activa, incentivando os cidadãos, através de sua revisão da história de Roma, a arcarem eles mesmos com o peso da responsabilidade cívica (Baron, 1993, 119-123).

No outono de 1402, morre Giangaleazzo, vítima de uma epidemia que assolava o norte da Itália. Apesar de outros príncipes, durante as décadas seguintes, tentarem retomar a iniciativa do duque de Milão, este fato foi decisivo para que Bruni se voltasse para as questões internas de Florença, iniciando uma 
segunda fase em seu pensamento político. Durante os próximos anos, tendo seu o impulso inicial reforçado por estes novos eventos, Bruni fez algumas retificações às suas afirmações anteriores e continuou sua defesa eloqüente do humanismo cívico contra a ameaça persistente agora da tirania, enfatizando o papel histórico de Florença neste embate. Em 1427, Nanni degli Strozzi, comandante das tropas de Ferrara e de descendência florentina, que foi um dos mais valorosos líderes da coalizão antimilanesa formada após a morte de Giangaleazzo, não resiste aos ferimentos da batalha de Ottolengo, vindo a falecer logo em seguida. A Bruni, que nesta época já havia alcançado o reconhecimento até mesmo fora da Toscana, foi pedido pelos ferrarenses que escrevesse um elogio em honra ao herói caído. Um ano depois - atraso devido a suas atividades como chanceler - Bruni elabora um panegírico que exercerá grande influência sobre o pensamento político peninsular. Reabilitando uma forma literária típica dos grandes estadistas republicanos do passado, aquela que será uma das obras mais marcantes do humanismo cívico italiano, a sua Oração Fúnebre para Nanni degli Strozzi, toma como base a famosa oração fúnebre pública de Péricles em honra aos primeiros atenienses tombados na guerra do Peloponeso, relatada por Tucídides em sua História da Guerra do Peloponeso, onde é realçada a proeminência cultural e política da cidade em razão de sua forma de governo e da virtude cívica dos seus cidadãos (Baron, 1993, 412-14). Conforme o historiador grego, a superioridade de Atenas sobre seus oponentes deve-se, entre outros fatores, principalmente às suas instituições e ao caráter de seus cidadãos (cap. 36): às suas instituições democráticas - uma criação original (o sorteio e o rodízio dos cargos são suas características principais), não copiada de seus vizinhos, e que, pelo contrário, tem servido de exemplo para outras cidades gregas (cap. 37); à bravura no momento de agir - ao contrário dos outros, que têm de recorrer a preparativos e estratagemas ou ainda à compulsão das leis, os atenienses estão sempre dispostos a enfrentar os perigos e não se perturbam nos momentos de provação, pois, cientes de que a coragem na luta pela pátria deve com justiça sobrepor-se ao resto, eles de bom grado estão dispostos a se sacrificar por ela (cap. 39); e 
também aos laços de fraternidade que permeiam o relacionamento entre os cidadãos atenienses - uns ajudam aos outros sem temer as conseqüências e jamais por mero cálculo de vantagens que obteriam, visto que aqueles que cuidam exclusivamente de seus próprios interesses são tidos como inúteis (cap. 40). Estas características fizeram com que Atenas sobrepujasse as outras cidades gregas também em beleza e em sabedoria (cap. 40 e 41). Ela é, como afirma Péricles, a escola política e cultural da Grécia (cap. 41) (Tucídides, 97102). (Uma descrição que, na verdade, se aproxima muito mais da república ideal de Aristóteles do que da democracia ateniense que conhecemos de outros textos).

Do mesmo modo, a estas três características, é dito de modo eloqüente em sua Oração, Florença deve sua superioridade sobre as demais cidades italianas. Entretanto, a afirmação do jovem historiador florentino - que sua cidade deve a sua particularidade ao fato de ter sido fundada por romanos antes de se deixarem corromper por César e seus sucessores - não levava em conta que outras colônias foram fundadas na mesma época em outras regiões da Península, e que, portanto, deveriam partilhar das mesmas qualidades. Esta dificuldade pôde ser contornada a partir de sua História do Povo Florentino (1415), com a sua descoberta de que, antes da vinda dos romanos, havia na Toscana um povo livre da sujeição tirânica: os etruscos. Em seu panegírico, Bruni funde estas duas visões: Florença deve a sua particularidade por descender destes dois povos, sendo em sua origem uma colônia de romanos que se mesclou com os habitantes etruscos. Assim como Atenas, também Florença, devido à sua originalidade, tem servido de escola para as outras cidades italianas. A sua eminência cultural - a cidade do Arno foi, nesta época, centro do humanismo e da língua vernácula - seria uma prova de que suas instituições políticas e o caráter de seu povo primavam na Península. (Daí a necessidade de Bruni matizar em seus escritos o credo político autocrático, de cunho medieval, dos ilustres letrados florentinos, Dante e Petrarca). A constituição florentina, conforme a Oração, promove a liberdade e a igualdade de todos os cidadãos. Ela 
é definida como uma forma popularis de governo, à medida que os cargos públicos são preenchidos através de um sistema de rodízio por sorteio (instituições que, somadas, caracterizam uma forma de governo democrática). $\mathrm{O}$ acesso a estes cargos está aberto a todos, acrescenta ele, contando que o candidato seja qualificado para assumi-los, pois esta república requer de seus cidadãos virtus e probitas (Baron, 1993, 414-15, 418-19 e 424; Pocock, 1975, 8791). Para Bruni, seguindo a concepção aristotélica, a virtude cívica exige a igualdade política, assim como a participação direta de todos os cidadãos no governo exige que todos comunguem esta mesma disposição ética. Esta concepção, que a partir da Oração conhecerá uma divulgação sem precedentes em toda Itália, já havia sido expressa anteriormente em sua famosa epístola $A d$ magnum principem imperatorem (1413): "O regime popular, que os gregos chamam de democracia... encontra sua metáfora no relacionamento fraterno. Os irmãos são pares e iguais entre si. O fundamento do nosso governo é a paridade e a igualdade dos cidadãos... Todas as nossas leis se voltam unicamente para isto: que os cidadãos sejam iguais, porque é somente na igualdade que se enraíza a verdadeira liberdade" (Garin, 33). É inquestionável o avanço com relação ao texto de 1400 , onde a única referência à forma de governo florentino diz respeito a um limite constitucional aos detentores do poder - o poder supremo está dividido entre nove pares, eleitos a cada dois meses; e os nobres das antigas famílias feudais têm o seu poder político limitado por leis. A intenção de Bruni, nesta segunda fase de seu pensamento político, é realçar a interdependência entre a igualdade ética e política, pilares da república.

Esta discussão e o seu impacto são frutos do contexto político singular de Florença, que viveu e ainda admirava a democracia. Certamente, houve antes de Bruni algumas explorações sobre a república antiga; mas, além de tímidas (em parte, por não poderem contar com fontes originais de informação, inacessíveis, nesta época), não visavam contrapor-se ao Império (uma vez que tanto estes escritores como os seus leitores não se sentiam ameaçados por ele). A interdependência entre pensamento político e as circunstâncias políticas da 
época, chave para a compreensão tanto da origem do humanismo cívico italiano quanto do seu impacto no plano das idéias e das ações nesta época, torna-se mais clara ainda se trouxermos dois exemplos de contato com a literatura republicana antiga num contexto político radicalmente diferente do de Florença de 1400. Longe de apontar para uma nova alternativa ao mundo político de então, a redescoberta da Política, na metade do século XIII, como atestam os comentários dos principais Doutores da Igreja da primeira tradução latina de Guilherme de Moerbeke, corroborou os valores de então. Isto se deve a um erro típico de interpretação da Idade Média (tão típico que os medievalistas cunharam a expressão interpretatio mediaevalis): a projeção da experiência e dos valores políticos de sua época nos autores clássicos que, a partir de então, passaram a ser estudados. Um exemplo deste erro podemos extrair dos comentários de Tomás de Aquino (o mais influente Doutor da Igreja), do primeiro capítulo do Livro I da Política, onde é comparado o regime político (politike arche) com o regime monárquico (basilike arche). "Governar (archein) e ser governado (archesthal) em rodízio" (1252 a 16) é, afirma Aristóteles neste trecho, o que caracteriza o primeiro, em oposição ao segundo, onde um governa sempre e os outros são sempre governados. Como vimos acima, esta distinção pressupõe uma virtude à qual cada uma das formas de governo está associada: a virtude cívica, da qual partilham todos os cidadãos, está associada à igualdade política; a virtude do monarca, que, como a do bom pai, deve-se à sua capacidade de tutelar aqueles que, como os filhos imaturos, são incapazes por si sós de promoverem o seu próprio bem, está associada à desigualdade política. A preferência de Aristóteles é nítida, e não precisa ser repetida. No entanto, esta distinção aristotélica entre o regime político e o monárquico foi totalmente apagada a fim de se adequar ao ideal medieval de seus comentadores. No comentário de Tomás de Aquino, tal adequação levou-o a apagar completamente a própria noção de um regime político. Segundo ele, esta passagem do início da Política refere-se a um regime em que o rei em parte governa (todos os seus súditos), em parte é governado (pela vontade de Deus). No seu comentário, politicus é uma qualificação positiva 
do regime monárquico - o regimen regale que obedece a Lei de Deus seria um regimen politicum et regale; assim como despoticus é a sua qualificação negativa - o regimen regale que segue exclusivamente o arbítrio do soberano seria um regimen despoticum et regale (Sternberger, 1978, vol. I, 45-53; vol. II, 30). Neste contexto político - onde a Santa Sé procurava colocar o Sacro Império RomanoGermânico sob a sua tutela - e intelectual - onde Aristóteles assumia uma autoridade incontestável, a ponto de merecer ser rigorosamente traduzido e comentado como a Bíblia - não poderíamos esperar outra interpretação. Também o silêncio sobre alguns conceitos é significativo: na primeira tradução da Política para o latim, o termo latino politia (tradução de Guilherme de Moerbeke para o grego politie) não é comentado em nenhuma passagem pelo Doutor da Igreja. Somente em 1438, no contexto de uma cidade que, como dissemos, já havia vivido e prezava a democracia, poderá Leonardo Bruni concluir a sua tradução latina da Política, na qual o termo grego politie estará traduzido corretamente pelo seu equivalente latino res publica (Meier, 1984, 565-67).

Um segundo exemplo, para tornar mais clara a interdependência entre pensamento e contexto político e a importância dela para a compreensão do pensamento político renascentista, é o De Regimine Principum ad Regem Cypri. Endereçada ao príncipe de Chipre, esta pequena obra permaneceu inacabada antes mesmo da morte de seu autor, Tomás de Aquino, em 1274 provavelmente, devido à morte prematura do jovem príncipe. Cerca de trinta anos após o seu início, ela foi completada por um dos seus discípulos mais próximos, o italiano Ptolomeu de Lucca, futuro bispo de Torcello. A diferença entre as duas partes desta obra é bem nítida. Na primeira, sobressalta o rigor lógico e a ausência de experiências históricas; na segunda, a argumentação frágil e desordenada é suprida com vários exemplos bíblicos e da história antiga e da Itália de sua época. Mas há uma outra diferença ainda mais interessante: enquanto que a primeira parte discute exclusivamente, dentro da visão normativa teológica medieval, as vantagens da monarquia; encontramos, na segunda, uma definição e uma discussão - embora desordenadas - da república. A politia - 
Ptolomeu usa a tradução latina de Guilherme de Moerbeke - deriva de polis, que significa a totalidade dos cidadãos. Encontramos a politia, continua, onde: os muitos governam a si mesmos (ela é um dominium plurium); os ofícios são limitados no tempo; eles reúnem-se freqüentemente em assembléias para deliberarem as coisas públicas; os governados são virtuosos, não estando sujeitos à altivez, à inveja e à discórdia; e os que governam estão sujeitos a punições. A forma de governo que possui estas características é denominada regimen politicum. Em sua caracterização da república dois exemplos surpreendentes para a época - são constantemente citados: a República Romana e Israel. Segundo ele, graças a sua forma de governo, os romanos e o povo de Israel puderam seguir plenamente um modo de vida político (politice vivunt) (Sternberger, 1978, vol. I, 58-70). No entanto, apesar de ter compreendido muito bem Aristóteles, a sua colaboração à obra iniciada por Tomás de Aquino não foi normativa - ao contrário do que pretende Sternberger. A sua preocupação central foi completar a obra inacabada de seu mestre, descrevendo formas de governo que sua época não conheceu, e desfazer o seu erro, descrito no parágrafo acima - ao interpretar o regimen politicum como um regimen regale que obedece a Lei de Deus, isto é, ao projetar valores de sua época naquele conceito aristotélico. Que Ptolomeu está preocupado exclusivamente com constatações empíricas, fica claro quando ele associa uma última característica ao regime político, qual seja, o fato que ele ocorre normalmente nas cidades - sendo Roma a única exceção - e que onde elas não existem é natural que o regime seja monárquico. Ptolomeu viveu numa época em que as cidades italianas não eram autônomas nem mesmo almejavam a autonomia política - politicamente, elas não tinham existência, como procuramos argumentar no início deste capítulo - e em nenhum momento ele esteve interessado em alterar esta situação. Em sua parte não há uma crítica à ordem vigente nem sinal algum do ideal da imitatio renascentista. Não há, portanto, nesta obra nenhuma ruptura entre as duas partes, mas sim uma complementação - o discípulo continua fiel à ideologia de seu mestre. É por isso, 
que ela não poderia ter qualquer efeito revolucionário, seja no plano das idéias ou das ações.

Se as afirmações de Bruni, nos seus primeiros escritos, continham uma boa dose de exagero - que os florentinos teriam herdado dos seus antepassados republicanos o espírito cívico e a forma de governo democrática era devido ao seu intuito de persuadir os seus concidadãos, através da fundação mítica de Florença, da excelência da república. Mais tarde, ele foi obrigado a constatar que a situação real de sua cidade distanciava-se cada vez mais do que preconizavam as suas obras, tornando-o mais pessimista quanto ao seu propósito inicial. Um fato foi de crucial importância para a sua inquietação. Vimos que na Oração, inspirada na descrição da Atenas mítica de Tucídides, a bravura de seus cidadãos é um dos fatores determinantes da superioridade de sua cidade sobre as outras. A ênfase nesta qualidade deve-se não só à ameaça externa, mas também à concepção republicana - provinda principalmente de Aristóteles, de quem o florentino fora leitor assíduo e tradutor esmerado - de que a coragem é a virtude cívica por excelência. Assim sendo, o cidadão armado, que ama a pátria acima de sua própria salvação, cujo exemplo mais digno foi Strozzi, tema central desta obra, deveria constituir o cerne, a espinha dorsal da sua cidade. Portanto, assim conclui a obra, ela jamais poderia contar, para a sua defesa, com tropas mercenárias. Quando em 1439 foi-lhe pedido mais uma vez que descrevesse brevemente a constituição de Florença, seu julgamento, expresso num panfleto escrito em grego, Sobre a Politeia dos Florentinos, foi de que a sua cidade havia se transformado há muito tempo, ao perder o espírito cívico (que, na verdade, sempre Ihe faltou) e ao deixar de ser um governo democrático (que, como ele mesmo já havia enfatizado anteriormente, depende deste mesmo espírito). Segundo sua análise, Florença veio a ser uma república democrática - onde todos são não só livres, mas iguais, por terem acesso a todos os cargos públicos através do sorteio e do rodízio - somente quando os seus cidadãos assumiram, eles mesmos, o dever cívico de defender a república pelas armas. Tão logo a sua cidade começou a recrutar mercenários - uma decisão tomada voluntariamente 
pelos cidadãos florentinos -, os nobres e os ricos começaram a ser mais influentes; pois, uma vez que o auto-sacrifício pela pátria passa a ser desconsiderado por ser um preço muito alto a ser pago pela cidadania, uma vez que o amor próprio supera o amor pela pátria, o conhecimento para confeccionar os estratagemas militares dos nobres (ainda presos aos valores guerreiros) e os recursos financeiros da burguesia (em particular, os banqueiros e os grandes mercadores) passam a ter um valor preponderante (Baron, 1993, 427-32, 435-39; Pocock, 1975, 89-90). Entre o fim do século XIV e o início do seguinte, esta é a conclusão que podemos tirar desta análise mais realista de Bruni, Florença tornou-se um regime misto de preponderância oligárquica, onde o povo geralmente aceita e raramente veta as leis, cuja preparação e a formulação estão nas mãos dos poucos e mais influentes. Situação que ele lastima e espera ver corrigida através de suas advertências.

A evolução da constituição dos florentinos descrita por Bruni vai de encontro às análises mais minuciosas de que dispomos hoje - apesar da escassa e confusa documentação que os historiadores modernos herdaram. Neste sentido, as considerações da Politeia são importantes para podermos avançar algumas conclusões. Como Bruni destaca em seu panfleto, a participação do popolo (basicamente, os artesãos, que formavam as guildas menores) tornou-se reduzida; pois, os critérios iniciais para a qualificação a um cargo (fazer parte da milícia e ser membro de uma guilda) transformaram-se radicalmente quando a necessidade de acumular recursos para custear mercenários, frente a ameaça dos inimigos, passa a ser a prioridade central dos florentinos. Certo é que esta transformação concretizou-se, definitivamente, ao longo do século XV, quando os accoppiatori passaram a ter o papel de confeccionar bolsas exclusivas dos representantes das guildas maiores para as três principais magistraturas e dos representantes das guildas menores para as magistraturas menores, os dois Conselhos, cujo único poder é o veto às decisões que lhes são encaminhadas. Numa outra fase, os grandes mercadores e os banqueiros, devido a sua maior disponibilidade de recursos para o erário público, acabaram se destacando dos 
demais representantes das guildas maiores, aumentando ainda mais o seu poder no governo. Assim, a frágil forma de governo popular, distante da Florença mítica de Bruni, transformou-se, em poucas décadas, num governo misto de preponderância oligárquica (formada pela grande burguesia, basicamente, os comerciantes e banqueiros, e pela nobreza), quando a qualificação para os principais postos de governo passou a ser discriminada.

Apesar do exagero dos primeiros escritos de Bruni, a sua repercussão foi estarrecedora, transcendendo os limites de sua cidade. A partir de 1430, o seu Elogio e a sua Oração passaram a ser lidas avidamente em quase toda a Península; e até 1460 foram as principais referências para as cidades livres em sua luta contra a tirania - embora jamais tenham sido suficientes para 0 seu propósito original, a criação de uma república democrática. Durante todo o século XV, mesmo com o governo de dois Medici, mesmo com todos os desvios que a constituição florentina sofreu ao longo destes anos, as descrições destas duas obras sempre se mantiveram vivas no espírito dos florentinos. No século $\mathrm{XVI}$, entretanto, a cidade do Arno conhecerá uma transformação radical: no plano das idéias, a constituição de Veneza passará a inspirar o pensamento político florentino, substituindo o mito florentino de Bruni; no plano político, a elevação de Veneza a modelo de imitação para os florentinos terá como conseqüência a ascensão definitiva dos Medici ao poder - um nome que estará até a metade do século XVIII definitivamente associado ao governo desta cidade. Esta mudança radical é ao mesmo tempo surpreendente, pois os florentinos, que, até então, se rejubilavam, como vimos, por terem uma forma de governo única, eram, nesta época, inimigos viscerais dos venezianos - a quem atribuíam uma forma de governo oligárquica. (Inicialmente, os florentinos esperavam que Veneza fosse a sua aliada natural, visto que somente as duas Repúblicas haviam sobrevivido às investidas de Giangaleazzo. Esta, entretanto, adotou uma política isolacionista, confiando na proteção natural de suas lagunas, na eficiência de sua diplomacia e no bom relacionamento comercial com as principais forças centrípetas da época, que até então Ihe haviam garantido a sua autonomia política. $O$ fato de alguns 
pactos serem firmados entre o doge e o duque reforçou ainda mais nos florentinos o sentimento de traição que nutriam pela República de San Marco) (Baron, 1993, 435-6 e 454-5; Gilbert, 1977, 180-2).

Até então, Veneza assistia, distante e impassível, o desenrolar destas lutas intermináveis que flagelavam o centro e o norte da Península. Foi a inimizade entre as duas cidades, somada à grande repercussão que o mito florentino alcançava em toda a Península, que levou os venezianos e seus simpatizantes a saírem desta imobilidade, buscando uma alternativa, nesta segunda metade do século XV, para aquela que passou a ser considerada a melhor forma de governo, a única digna de um povo livre. No auge da Renascimento, as principais famílias do patriciado veneziano, que há quase dois séculos governavam inquestionavelmente a cidade, tiveram que se empenhar em identificar a constituição de Veneza com os modelos clássicos do republicanismo. O seu interesse em revidar a (idealizada) república democrática florentina visava, além do mais, ter uma base ideológica de legitimação tanto externa (para os seus propósitos diplomáticos) quanto interna (para manter os seus governados unidos e justificar os sacrifícios destes pela cidade). Os governantes venezianos já contavam, para a sua propaganda, com duas autoridades do maior peso: Tomás de Aquino, que em seu $O$ Governo dos Príncipes considera o povo veneziano livre, pois de todos os governantes do norte da Itália somente o doge teria o seu poder limitado e não seria, portanto, um tirano; e Petrarca, que elogia, em uma de suas Letras, a estabilidade do governo veneziano. Entretanto, o debate ideológico atual exigia, para a sua legitimação, alguma similaridade com a tradição grecoromana; o que fez com que os governantes venezianos buscassem, ansiosamente, humanistas da nova geração para reescrever a história de Veneza, enfatizando a singularidade das suas instituições políticas e o espírito cívico de seus governantes, causas da sua harmonia interna e, portanto, de sua durabilidade. O primeiro a se notabilizar por esta empreitada - a ponto de marcar definitivamente o mito veneziano, que tanto influenciará o debate futuro sobre 0 republicanismo - foi o filólogo grego Giorgios Trapezuntios. Ele fora contratado 
por Francesco Barbaro, um dos mais influentes patrícios venezianos de seu tempo, para vir a Veneza lecionar grego. Em 1451, ele escreveu uma carta a Barbaro afirmando que os fundadores da República Veneziana haviam seguramente se inspirado nas Leis de Platão - nesta época, a luta ideológica antiflorentina deveria ser também antiaristotélica. Segundo ele, o motivo pelo qual a vida desta cidade tem sido tão duradoura e tão feliz está no fato dela ser um república mista de preponderância aristocrática. Esta afirmação veio tão de encontro aos anseios das famílias do patriciado veneziano, que Barbaro encomendou a ele, prometendo uma rica recompensa, uma introdução à sua tradução das Leis, na qual fosse salientada a similaridade entre a teoria de Platão e a prática política de Veneza. A partir de 1460, com a publicação do livro, dedicada ao doge, e com a nomeação, pelo Senado, de Giorgios Trapezuntios para a cadeira de humanidades e retórica na Escola de San Marco, esta idéia passa a ser parte da propaganda oficial de Veneza. Evidentemente, a idéia de que a melhor forma de governo está associada à mistura da monarquia, da aristocracia e da democracia, representados pelo doge, pelo Senado (a sua parte preponderante) e pelo Consiglio Maggiore, respectivamente, não pode se confundir com o intrincado e engenhoso sistema de limites e controles institucionais descrito por Políbio. O que contava para as famílias dos patrícios detentores do poder era o fato de Platão, no Livro III das Leis, entender o governo misto como aquele que está entre a monarquia e a democracia, ou seja, uma forma de governo onde o elemento aristocrático é determinante. Assim, estas famílias do patriciado veneziano agarraram com todas as forças a oportunidade de encobrir o seu regime oligárquico sob o manto legitimador da aristocracia associada, na tradição, ao ideal de virtude (os aristoi, os ottimati, são os melhores porque virtuosos) (Gilbert, 1977, 183-5).

A esta concepção oficial da constituição veneziana, os florentinos reagiram, formando dois grupos antagônicos. É o que se depreende do debate político deflagrado com a morte de Cosimo Medici, em 1465. Sem dúvida alguma este debate foi, nesta época, guiado sobretudo por razões emocionais, e não pelo 
que realmente diferenciava as duas constituições - as duas Repúblicas, como dissemos, eram inimigas. De um lado estavam aqueles que, reforçando o mito florentino, reafirmavam que a glória alcançada pela sua cidade, a supremacia a que chegaram, se comparada às outras cidades, deveu-se à preponderância do elemento democrático de sua forma de governo, à medida que os cargos públicos estavam abertos a todos e que eram preenchidos em rodízio através do sorteio, e ao espírito cívico de seus cidadãos, dispostos a qualquer momento a se sacrificarem pela pátria - Bruni, como dissemos, havia sido alçado a ideólogo oficial da cidade. Do outro lado, entre os defensores da constituição veneziana, temos um único humanista florentino de destaque, o chanceler Poggio Bracciolini (que, no entanto, tinha razões pessoais para estar insatisfeito com a sua cidade, chegando a ameaçar deixá-la para viver em Veneza, devido às taxas, injustas em sua opinião, que o governo o obrigava a pagar) e alguns integrantes das grandes famílias, provenientes das guildas maiores e da nobreza (responsáveis maiores pela divulgação do mito veneziano em sua cidade). Entre estas, por sua vez, dois grupos se destacaram: um, circunscrito aos admiradores dos Medici, imaginava imitar a constituição veneziana com um membro desta casa como doge ao lado de um conselho limitado às famílias leais a ele, como uma forma de garantir a estabilidade e a permanência dos Medici no poder; outro, sonhava com um doge florentino, não necessariamente um Medici, como primus inter pares ao lado de um conselho representado pelas principais famílias florentinas (Gilbert, 1977, 187191; Pocock, 1975, 100-4). Entretanto, por razões pragmáticas (tanto a diplomacia, preocupada em buscar alianças que enfraquecessem a política externa veneziana, quanto a nascente oligarquia, preocupada em acobertar o seu distanciamento para com a grande maioria dos cidadãos, que permaneciam fieis ao ideal republicano democrático, se beneficiavam do mito florentino), a rejeição ao mito veneziano durou até o final do século XV.

Mais tarde, com a expulsão dos Medici, em 1494, ainda podemos constatar a fidelidade a este ideal com a ascensão de Savonarola, que pregava em seus sermões a substituição do sistema atual de governo (montado 
cuidadosamente pelos Medici para garantir a influência de poucas famílias ambiciosas sobre a comunidade, que, segundo ele, impedia a sua unidade e harmonia) pelo que ele designava antico vivere popolare, através da criação do Consiglio Grande (reunindo representantes de todas as esferas sociais) e da conversão moral (exortando todos os cidadãos a colocarem o bem comum acima de seus interesses privados) - do mesmo modo que Bruni, o seu objetivo era instituir a igualdade ética e política. Embalado pelo clamor geral de regeneração religiosa e pelo seu carisma, Savonarola, no entanto, havia ido longe demais em suas pretensões políticas: a implantação do Consiglio Grande fez com que as principais famílias das guildas maiores e os nobres reagissem e, em nome de um pretenso aperfeiçoamento institucional, exigissem a constituição de um Senado, acento das principais famílias e centro das decisões políticas, e de um doge, seu par. Assim, seguindo o modelo veneziano, em 1502, foi criado o gonfaloniere vitalício, com a eleição de um nobre, o doge florentino, e, em 1512, finalmente, o Senado. Para tanto, não foi derramada uma única gota de sangue: Savonarola não compreendera que o povo estava dividido entre o seu sentimento republicano e a necessidade de ceder o poder aos mais ricos e aos de maior habilidade militar. Depois de um curto período de duração, a "república democrática" de Savonarola foi suplantada por uma "república aristocrática", na verdade, um regime misto que concentrava no Senado, ocupado vitaliciamente pelos membros das famílias mais proeminentes e ricas, as principais funções políticas (entre elas, eleger os magistrados dos principais cargos públicos e das embaixadas, nomear administradores para os territórios ocupados e administrar as finanças públicas) e que concedia ao Consiglio Grande, agora composto exclusivamente pelos representantes dos guildas menores, funções secundárias (dentre todas, a mais relevante era o poder de veto por maioria simples aos projetos de leis financeiras elaboradas pelo Senado, com aprovação de três quartos de seus membros). Quinze anos depois, dá-se uma outra troca de regime em Florença, novamente os Medici tomam o poder, mantendo das instituições anteriores somente a fachada, como escudo ideológico da sua tirania (Gilbert, 1977, 193-7). 
Mais uma vez, meio século após a publicação de Sobre a Politeia dos Florentinos, completa-se o ciclo analisado por Bruni em seu panfleto: a "república democrática" (centrada no Consiglio Grande) é substituída por um regime misto de preponderância "aristocrática" (inspirada no modelo veneziano, na qual a parte menor e economicamente mais influente da sociedade tinha uma participação maior no governo), que, por sua vez, é substituída pela tirania (também encoberta sob o manto legitimador do mito veneziano). Vale lembrar, com relação a estas considerações, que, desde o nosso ponto de partida, apesar da interdependência dos três pilares da república, o seu elemento determinante, o seu princípio (para usar uma expressão do século XVIII) é a homogeneidade da conduta ética dos seus cidadãos. Sem a igualdade política e sócio-econômica, certamente, a virtude não sobreviveria, como argumentamos acima. Esta é, para usar uma outra expressão, a alma da república. Quer dizer, uma república que desconsidera a igualdade política ou a igualdade sócio-econômica é imperfeita, não podendo durar; uma república que desconsidera o espírito cívico dos seus cidadãos não pode existir enquanto tal - seria uma forma de governo onde o princípio que possibilita a igualdade não estaria presente.

No final do século XVI, o mito de Veneza estará tão difundido entre os políticos, publicistas e escritores das duas principais cidades da Itália - "o mais belo e melhor governo não só no nosso tempo, mas, provavelmente, de todos os tempos", o governo que "há séculos dura, sem conhecer sedições ou discórdia", são afirmações comuns nesta época -, que o republicanismo passa a assumir definitivamente feições aristocráticas. No século XVII, este mito ultrapassará as fronteiras da Península e encontrará ressonância em toda Europa. Entre uma série de importantes autores republicanos de pretensa inspiração platônica (Bartolomeo Cavalcanti, Niccolò Sabellico, Gerolamo Garimberto, Giovanni Maria Memmo, Giasone de Nores, Pompeo Caimo, etc.), vale a pena destacar alguns nomes - pela repercussão que tiveram na Itália e na Inglaterra, em particular, para James Harrington. Quebrando o paradigma que até então reinara em Florença, logo no início do século XVI, Francesco Guicciardini, em seu Del 
Reggimento di Firenze, propõe para a sua cidade uma forma de governo mista, na qual a signoria representaria o elemento monárquico; o Conselho dos ottimati (os melhores pela sua virtude, que, na verdade, coincidem com os mais ricos e com os nobres), composto de cento e sessenta a cento e oitenta membros, o elemento aristocrático; e o Grande Conselho, eleito pelos cidadãos com direito a voto, o elemento democrático. Tomando o mito veneziano como modelo, Guicciardini concentra nos ottimati a parte maior do poder, sob a alegação de que a ruína da República de Savonarola deveu-se à constituição de um governo popular, ao contrário de Veneza. Para o florentino Donato Giannotti, em sua obra Della Repubblica de' Veneziani, publicada em 1540, embora já circulasse em Florença entre 1527-28, o motivo que fez de Veneza uma República "eterna" deve ser encontrado, em primeiro lugar, no Senado (a parte principal da mistura), cuja função é o discernimento sobre as principais questões públicas (sobre a guerra, a paz, os acordos com os vizinhos, as leis, etc.); em seguida, no Consiglio Maggiore, cujas tarefas são decidir acerca do que foi ponderado no Senado e nomear os magistrados; e, finalmente, no doge, que tem como função dar força à execução das leis (Battaglia, 298-302; Fink, 18-19; Mattei, 1973, 636-7).

Para o famoso e influente teórico do governo misto veneziano, Gasparo Contarini, que em 1543 edita De Magistratibus et Republica Venetorum, Esparta é muito semelhante à sua Veneza. Nesta, a representação da república cabe à parte régia, ao doge, em nome do qual são publicados os principais documentos públicos. Além desta atividade, o doge divide as outras atribuições menores com seis conselheiros, eleitos cada qual por uma das seis tribos, na qual foi dividida a cidade. Estando presente na sua maioria, os conselheiros podem agir sem o doge, enquanto que este não pode agir sem a presença de quatro conselheiros. As atribuições maiores do doge e dos seus conselheiros são divididas com o Collegio di Savii, um comitê formado por dezesseis membros do Senado. Outras importantes funções são distribuídas entre o Senado (a elaboração das leis) e o Consiglio de' Dieci (cuja principal função é evitar que as diversas instituições usurpem as suas atribuições). Além da ratificação das leis 
elaboradas pelo Senado, a maior incumbência da parte popular, o Consiglio Maggiore, no qual tomam assento todos aqueles cujas famílias constam no Libro d'Oro e que possuem mais de vinte e cinco anos, é a eleição dos magistrados, em particular, o doge (vitaliciamente), os senadores (anualmente) e os membros do Conselho (anualmente) e do Colégio (a cada seis meses). No entanto, os verdadeiros e próprios magistrados da República são os ottimati, a parte aristocrática, a melhor parte (eleitos pela sua virtude, e que pertencem às famílias mais ricas ou mesmo do patriciado, justamente as que mais prezam o cultivo das habilidades espirituais), com assento no Conselho, no Colégio e no Senado. Veneza teria ordenado as suas instituições para a verdadeira finalidade do governo civil: a felicidade e a prosperidade do homem; entretanto, a felicidade só é alcançada com a virtude, que, por sua vez, é um apanágio de poucos. Outro influente autor Paolo Paruta, em sua obras, Della Perfettione della Vita Politica (editada quatro vezes em Veneza, entre 1579 e 1600) e Discorsi Politici (1599), segue, com alterações de pouco significado, as mesmas descrições de seu conterrâneo Contarini, e chega à mesma conclusão a respeito da primazia dos ottimati no governo misto para se estatuir um regime eterno e próspero. A sua preocupação central é mostrar que, primeiramente, a mistura das formas de governo, entendida como um sistema de pesos e contrapesos, não basta para evitar a revolução, como, segundo ele, depreendemos da experiência de Roma, cuja causa de sua queda deveu-se à distribuição eqüitativa do poder entre as três instâncias, privilegiando indevidamente os cônsules e a Assembléia do Povo (os elementos monárquico e democrático, respectivamente); e que, em segundo lugar, Veneza, ao proporcionar a "vida cívica" (ou, para usar outra expressão sua, a "liberdade pública") para os seus cidadãos, conseguiu por fim àquilo que Roma não pôde evitar - o ciclo de corrupções -, ao colocar a virtude no centro de seu governo (Fink, 19-20, 28-31 e 36-9; Mattei, 641-2 e 647).

Estas considerações nos levam às seguintes conclusões. Com relação à Florença, podemos dizer que as suas experiências políticas não escaparam ao drama que perseguiu as demais cidades italianas do 
Renascimento: instáveis, elas sucumbiram a uma oligarquia, que posteriormente se transformou numa tirania. Exceção a esta regra geral foi Veneza: único caso na Península, a sua constituição permitiu que um grupo restrito de famílias de patrícios se mantivesse estavelmente no poder, evitando as revoluções políticas. Por estes motivos, nenhuma das experiências estudadas neste capítulo pode se enquadrar no constitucionalismo - os mecanismos constitucionais que descrevemos foram débeis demais para evitar a sujeição da maioria dos cidadãos. Com relação às principais doutrinas políticas, podemos dizer que o primeiro teórico não medieval a elaborar uma teoria política consistente e que se tornou paradigma nas discussões políticas subseqüentes foi o republicano Bruni. A sua preocupação central não era descritiva, e sim normativa: a grandiloqüência do Elogio, dos Diálogos e da Oração visava educar politicamente o seu povo, realçando o espírito cívico e as instituições democráticas de seus antepassados; a sua preocupação central era a criação do mito da república democrática florentina, modelo a ser perpetuado pelas gerações vindouras. Por outro lado, o revigoramento do ideal republicano, para Bruni a única solução para a crise política pela qual passava Florença, negligencia - esta é a sua grande fraqueza a equiparação das posses, a homogeneização das atividades econômicas na agricultura e o abandono das atividades lucrativas, apoiando-se exclusivamente na paideia. Afinal, como reabilitar a virtude cívica e a igualdade política, valores interligados, onde impera o comércio e a especulação financeira? Sem uma igualdade de base, sem uma igualdade material efetiva (através da qual a autonomia econômica e o ócio são garantidos para todos os cidadãos), tanto a educação cívica (ou mesmo a religião, os preceitos e espetáculos cívicos) quanto a superestrutura republicana (através da qual a participação direta de todos no governo é garantida) não têm sustentação. O mesmo nós podemos dizer dos humanistas cívicos que viam na constituição veneziana o exemplo de uma forma de governo perfeita, imortal. Também eles, rompendo com o mundo medieval, vieram a ser o ponto de referência do pensamento político - não só na Itália de sua época como também nos séculos seguintes em boa parte da Europa; também 
eles negligenciaram a igualdade de base como condição prévia da virtude cívica. Mas foram além: devido à luta ideológica que travavam contra o mito florentino, eles se viram obrigados a desprezar a igualdade política e a educação pública para a formação da personalidade cívica dos cidadãos. Entretanto, ao contrário do que pensam os intérpretes contemporâneos de nossa Introdução, nenhum destes autores italianos, apesar de suas diferenças, pode ser considerado precursor da Revolução Americana - este papel caberá, como veremos, a um grupo de teóricos e publicistas ingleses dos séculos XVI e XVII, além do grande pensador francês, Montesquieu.

Não poderíamos encerrar este capítulo sem antes de tecer, ainda que de forma rápida, alguns comentários sobre aquele que foi um dos maiores teóricos políticos desta época. Maquiavel não pode ser considerado nem um republicano clássico (Sasso foi provavelmente o primeiro a defender, e foi seguido mais tarde por Sternberger em 1974 (1980, 29-111), a tese do Maquiavel republicano), nem um precursor do republicanismo moderno, como desejam os seus intérpretes citados na Introdução. Em suas obras, o florentino rejeita o humanismo cívico, subvertendo as suas concepções centrais. Em suas Histórias Florentinas, Maquiavel subverte a concepção de História do humanismo cívico originada dos antigos. Para este, a finalidade da História era a formação do caráter cívico da geração atual através da rememoração dos grandes feitos do passado (cujos exemplos mais marcantes encontramos nas obras de Tirteu e de Bruni, como vimos acima). A missão dos historiadores seria, portanto, inculcar o espírito cívico nos leitores e ouvintes, exortando-os a imitarem aquelas ações do passado que pela sua magnanimidade, honradez, liberalidade, coragem, ou outra qualidade nobre, mereceram servir de modelo para as ações futuras e dignas do reconhecimento público. Maquiavel retruca esta concepção, ao concluir, no início do Livro $V$, que "a coisa feitas por nossos príncipes, no país e além de suas fronteiras, não podem, como aquela dos antigos, ser lidas com admiração por sua virtù e grandeza", pois, pelo contrário, aos seus feitos está associado as "trapaças e artimanhas". Para ele, a finalidade da História não é estimular a imitação de 
ações dignas de serem seguidas, mas corrigir os erros do passado; não é a moralidade, mas a utilidade (Skinner, 1988, 121-5; Arendt, 1979, 69-78).

No Príncipe, Maquiavel subverte a concepção de virtude, que tanto impregnou o humanismo cívico do século anterior. Em primeiro lugar, ela é concebida como uma habilidade com a qual só poucos podem contar - os fundadores das cidades e os grandes líderes políticos; pois somente nestas grandes personalidades, jamais no povo, encontraríamos a força dinâmica necessária para impelir a ações humanas para além dos desígnios da fortuna. Em segundo lugar, ela obedece aos ditames da necessità, ou seja, o governante "virtuoso" não deveria ser sempre bom (sempre liberal, parcimonioso, clemente, honrado e amado), mas sim agir em conformidade com as circunstâncias, que, por estar continuamente sujeita a mudanças, faz com que ele ora precise ser bom, ora, mau (cruel e hipócrita, ao encobrir suas verdadeiras intenções sob o véu da liberalidade, da parcimônia, da clemência, da honradez à palavra). príncipe prudente, lemos no capítulo XV do Príncipe, "não se preocupará em ser censurado por aqueles vícios sem os quais dificilmente manteria sua posição, e descobrirá que, na maioria dos casos, o que é tido como virtude, se lhe obedecer, será a sua ruína, e o que é tido como vício, se lhe obedecer, Ihe dará segurança e estabilidade em seus desígnios". Virtude passa a ser o uso adequado da força e da astúcia (que, sob a ótica dos humanistas cívicos, são qualidades próprias dos animais) guiadas por impulsos (que, também sob este ponto de vista, são corrompidos), como o interesse particular, o egoísmo e o desejo de poder (Baron, 1992, 38-9; Skinner, 1988, 68-76).

Finalmente, nos seus Discursos, Maquiavel subverte a concepção de homogeneidade, tão cara ao humanismo cívico. Ao principado, ele contrapõe as formas de governo misto, as repúblicas "mais perfeitas". Apesar das frases textuais de Políbio que aparecem ao longo desta obra, sem citá-lo, as conclusões do secretário florentino são radicalmente diferentes. No seu famoso Livro II, é afirmado que, enquanto os principados, cujo exemplo mais bem acabado é a monarquia absoluta francesa, propiciam a seus cidadãos um vivere sicuro, isto é, 
a garantia da inviolabilidade das coisas e das pessoas, a característica determinante das repúblicas mistas, como Esparta, Roma e Veneza, é o vivere libero. A primeira consideração que devemos fazer é a de que não podemos reduzir o bios politikos, o modo de vida republicano, cuja característica central é a homogeneidade (com relação ao comportamento, à atividade econômica e à distribuição das posses), ao vivere libero (característica central do ideal democrático ateniense). A segunda consideração - e é esta que nos impede de considerá-lo um teórico do constitucionalismo - é a de que esta "liberdade" é entendida, nos Discursos, como um privilégio, como um meio para se atingir algo, e que pode se estender a todos os cidadãos (como na Roma republicana, onde todos os romanos tiravam proveito dos povos conquistados) ou a uma única classe social (como em Veneza, onde algumas poucas famílias patrícias governam em proveito próprio). Além do mais, as formas distintas de governo, a segurança e a "liberdade" (larga ou estreita) que elas propiciam, são ditadas pela necessità. Assim, a grandeza de uma cidade ou nação advém, para Maquiavel, da adequação de suas constituições às circunstâncias do momento; ou ainda, a sua estabilidade não está mais associada a uma determinada forma de governo e aos valores éticos que ela propicia, e sim à capacidade de seus legisladores ou de seus governantes de adaptarem as instituições políticas às exigências do tempo. Este é o motivo, segundo ele, pelo qual Roma e a França tiveram mais sucesso que Esparta e Veneza (Cadoni, 478-484). Curiosamente, apesar deste seu empreendimento subversivo, Maquiavel assumirá, na reabilitação do humanismo cívico iniciado por Harrington, um século mais tarde na Inglaterra, um papel de destaque, ao lado dos seus compatriotas republicanos desta época (em particular, Guicciardini, Giannotti, Contarini e Paruta) e dos republicanos da Antigüidade (em particular, Aristóteles e Políbio). Talvez esta seja a origem de um mal-entendido que perdura ainda hoje. 


\section{INGLATERRA: O NASCIMENTO DO CONSTITUCIONALISMO E A REPÚBLICA DE JAMES HARRINGTON}

Após as considerações dos dois últimos capítulos, pretendemos agora datar a origem das primeiras doutrinas constitucionais e a primeira experiência propriamente constitucional. Para a compreensão destas doutrinas e de como elas contribuíram para a instituição do primeiro regime genuinamente constitucional, entretanto, é necessário relacioná-las com as circunstâncias políticas de sua época. Um breve preâmbulo histórico, portanto, é imprescindível. O ordenamento político medieval inglês obedecia à concepção antiga de família (também conhecida como casa). Internamente, ela se caracterizava pelo domínio, fundado na posse da terra, do senhor (pater-familias) sobre seus vassalos (que arrendavam suas terras em troca de serviços) e seus súditos imediatos (artesãos e comerciantes, que viviam nos burgos sob sua proteção, além de servos e até mesmo escravos); externamente, essas famílias deviam, por sua vez, serviços (que, como acima, se resumiam fundamentalmente na proteção militar contra seus inimigos) à Igreja, porta-voz de Deus (Rei dos reis, Pai de todas as famílias, de quem, segundo São Paulo, todo poder emana). O rei, dispondo de poucos recursos, era obrigado a reunir seus pares sempre que necessitava de apoio financeiro e material para empreendimentos de interesse geral. Estas reuniões, chamadas "parlamentos", sofreram, no início do século XIV, mudanças estruturais importantes. Inicialmente limitada exclusivamente às grandes casas feudais, gradualmente, tornou-se costume convocar também os representantes dos cavaleiros e dos habitantes dos burgos. (As grandes casas - os duques, marqueses, condes, viscondes e barões -, formavam o pequeno grupo que constituía a verdadeira nobreza feudal, cuja origem remontava muitas vezes à época carolíngia; os cavaleiros - membros da gentry, de origem humilde e sem títulos - foram armados pelos chefes destas grandes famílias no intuito de servilas, sendo-lhes cedido, para tanto, uma certa extensão de terra com os correspondentes trabalhadores). A partir de então, constituiu-se a Câmara dos 
Lordes, assento da alta nobreza, e a Câmara dos Comuns, assento da baixa nobreza e da burguesia nascente, nas quais deliberava-se separadamente as questões trazidas pelo rei. Evidentemente, esta divisão institucional espelhava a relação social que havia entre estes dois grupos: cavaleiros e habitantes dos burgos ainda estavam (uns mais outros menos) presos a laços feudais de dependência para com as poucas famílias que formavam a alta nobreza. Este ordenamento foi sensivelmente abalado pela dinastia Tudor, ao longo do século $\mathrm{XVI}$. A longa luta entre as grandes famílias no século $\mathrm{XV}$, conhecida como a Guerra das Rosas, permitiu a Henrique VII a implantação da Reforma (1529-40) que enfraqueceu definitivamente os dois principais poderes feudais: confiscou as riquezas da Igreja Católica e vendeu as terras desta para a baixa nobreza e para a burguesia nascente, seus aliados, livrando os novos proprietários das obrigações de vassalagem. A partir da Reforma, conseqüentemente, o relacionamento entre a coroa e o Parlamento alterou-se sensivelmente: à medida que os cavaleiros e os burgueses se favoreciam com a política realista, crescia 0 poder dos comuns para com os lordes e a sua dependência para com o rei, de tal modo que o Parlamento, antes centro de deliberação das grandes famílias feudais sobre os empreendimentos reais, passou a ser instrumento de sua vontade - sob os Tudors o Parlamento foi convocado raramente, e unicamente para referendar automaticamente as decisões reais. A monarquia inglesa dava os primeiros passos - os próximos seriam inevitavelmente a criação de uma burocracia profissional e um exército permanente - na trilha de suas vizinhas continentais (Hill, 54-8; Nippel, 177-80).

Esta situação foi alterada com a ascensão da dinastia Stuart. No início do século XVII, inicia-se uma luta política entre o Parlamento e a coroa, que culminará na Revolução de 1642. Para abastecer o tesouro público - necessário para garantir a independência econômica para o seu projeto político -, Jaime I aumentou tarifas e estabeleceu novas taxas sobre as importações sem 0 consentimento do Parlamento. Uma vez rompida a harmonia entre os comuns e a coroa, que caracterizou o governo dos Tudors, ambas as partes lançarão mão da 
tradição para justificar os seus direitos e privilégios. Eliminados os inimigos internos e externos (derrota da Armada espanhola) da coroa, os beneficiados da política dos Tudors sentiam-se mais independentes e fortalecidos para zelarem pelos seus próprios interesses. Reunidos em 1610, os comuns protestaram contra estas medidas, alegando que sempre foi competência do Parlamento aprovar ou recusar qualquer ação da coroa que afetasse a propriedade dos seus súditos. A coroa revidou esta alegação afirmando que estas medidas estariam entre as suas prerrogativas - pois, além de determinar a política externa, declarar guerra ou paz, nomear comandantes militares, juizes e funcionários, conceder o título de nobreza, cunhar moedas, conceder perdão, seria competência exclusiva do rei não só convocar, adiar ou dissolver o Parlamento, mas também decidir se precisaria ou não do acordo de uma outra instância para levar adiante sua intenção. Este conflito inicial acirrou-se sensivelmente à medida que, para contrabalançar a pressão dos comuns, Jaime I buscou apoio na alta nobreza (ampliando a sua corte, através da concessão de privilégios principalmente aos seus filhos mais novos, que não possuíam terras) e na Igreja inglesa (reavendo suas terras e reaproximando-se da Espanha, no intuito de contrabalançar o avanço dos protestantes, fortemente representados no Parlamento), invertendo o processo iniciado pelos seus antecessores. Entretanto, as reivindicações do Parlamento não se limitavam exclusivamente à proteção da propriedade dos súditos da coroa. Em 1621, preocupado com o destino dos protestantes no continente, o Parlamento sugeriu ao rei que desistisse do seu plano de casar o seu filho com uma princesa espanhola e que declarasse guerra à Espanha. Como era de se esperar, Jaime I respondeu que assuntos externos eram prerrogativa exclusiva do rei. Quando os comuns retrucaram, através da primeira grande denúncia pública da política do rei (a famosa Protestation), onde era dito que o Parlamento era herdeiro de antigos privilégios e jurisdições, a sua reação foi dissolvê-lo. Sem que houvesse qualquer avanço sobre esta questão - isto é, sobre os limites de competência de cada uma das instâncias -, o conflito aguçou- 
se a ponto de provocar a sua abdicação, logo em seguida (Hill, 64-7; Nippel, 21824 e 234-5).

Carlos I, que o sucedeu ao trono, em 1625, foi ainda mais drástico que seu pai: utilizou empréstimos forçados e aprisionou arbitrariamente os que se recusavam a pagar. O Parlamento reagiu, em 1628, com a Petição de Direito, que pretendia impedir o rei de fixar taxas sem o seu consentimento, prender arbitrariamente seus súditos e constituir e manter um exército permanente (objetivo primordial da coroa para se perpetuar no poder). Inicialmente, Carlos I se viu obrigado a aceitar a Petição; mas já no ano seguinte dissolveu o Parlamento, prendendo vários líderes parlamentares e instaurando um governo estritamente pessoal, que sucumbirá onze anos depois. Durante este período, a oposição organizou-se e expandiu-se - tendo sempre em seu núcleo os comuns. Um caso com grande repercussão foi o ship-money. Instituída inicialmente para os habitantes das cidades costeiras, com o objetivo de fortalecer a marinha de guerra, esta taxa estendeu-se, a partir de 1635, para todo o reino. Alegando violação da propriedade privada pelo rei, uma vez que esta taxa não contava com o consentimento do Parlamento, o líder parlamentar John Hampden, foi condenado e preso, em 1637, por se recusar a pagá-la. Seguindo o exemplo deste líder, generalizou-se a recusa do pagamento de taxas entre 1639 e 1640. Nesta mesma época, um importante fato veio a enfraquecer ainda mais o poder do rei. Na Escócia, a baixa nobreza tinha-se libertado do controle da Igreja, da alta nobreza e da coroa. Ao tentar estender a sua política para a Escócia, Carlos I provocou uma revolta nacional que encontrou forte simpatia na Inglaterra. Quando esta foi invadida por um exército escocês, em 1639, a ausência de qualquer apoio popular, assim como a absoluta falta de meios (agora originadas pelas recusas em pagar as taxas), obrigaram Carlos I a chegar a um acordo (Hill, 67-74; Nippel, 226-34).

Desde 1629 Carlos I regia sem convocar o Parlamento. Em 1640, a coroa estava falida - antes mesmo de conseguir chegar ao seu intento, qual seja, a construção de um aparelho burocrático profissional e de um exército 
permanente; os escoceses recusavam-se a abandonar a Inglaterra sem uma indenização; e, por sua vez, o exército inglês enviado contra eles tinha se amotinado, por falta de soldo. Já não era mais possível evitar a convocação de um Parlamento. O primeiro (Short Parliament) foi dissolvido por Carlos I após três semanas, quando o rei percebeu que deveria ceder muito para obter a sua cooperação; mas, em novembro de 1640, o rei teve de render-se ao segundo (Long Parliament). Dois outros motivos fizeram com que a balança do poder deste Parlamento fosse ainda mais desfavorável à coroa: a erosão do sistema de patronagem (por falta de dinheiro esta não podia cooptar, como antes, os lordes para a sua causa) e o aumento do eleitorado (crescendo para um terço da população masculina adulta, esta nova massa de eleitores reforçava ainda mais o poder dos comuns). O avanço do Parlamento sobre as pretensões do rei tornouse, portanto, inevitável. É importante notar que, como antes, seus ataques se dirigirão sempre ao governo do rei, e não à monarquia - seu argumento, diziam, era fundado na tradição: o rei, que tinha prerrogativas próprias, não obedecia àquelas do Parlamento. Sua intenção, portanto, não era revolucionária, e sim estritamente conservadora: reforçado em seus poderes, o Parlamento avançou sob a alegação de ser o protetor do Antigo Regime (a fundamental law), que o governo violentara. Este argumento, evidentemente, era revidado pelos realistas, que reafirmavam, à medida que o Parlamento avançava em suas reivindicações, ser este o violador do Antigo Regime. Esta contraposição ficou clara já na primeira medida tomada pelos comuns - o impeachment do mais hábil ministro da coroa, o conde de Strafford. Enquanto os primeiros acusaram-no de alta traição contra o reino, por ter usurpado competência do Parlamento; ele revidou, acusando-os de usurpadores (no final, valeu a pressão dos comuns, que contaram sucessivamente com a aceitação dos lordes e do próprio rei para prendê-lo e, posteriormente, executá-lo). Outro avanço significativo veio com a convocação do próximo Parlamento, no início de 1641, quando rei foi obrigado a aprovar o Triennial Act, segundo o qual a convocação do Parlamento passava a ser automática (a cada três anos e por um período mínimo de cinqüenta dias) e a 
sua dissolução ou adiamento só seria permitido se fosse por ele aprovado. Várias prerrogativas reais foram extintas e o Parlamento começou a exigir a sua participação na condução do governo. A pressão parlamentar foi arrebatadora. Entre os ministros do rei houve execuções, detenções e muitas fugas para o exterior; e quando a Irlanda se revoltou, neste mesmo ano, aproveitando-se da crise política de seus colonizadores, o Parlamento recusou-se unanimemente a confiar a Carlos I um exército destinado à sua reconquista. Em seguida elaborou - Militia Bill, que concedia ao Parlamento a nomeação dos altos oficiais do exército. Tendo o seu projeto imediatamente vetado pelo rei, as duas casas aprovaram, agora sem a sua consulta, a Militia Ordinance e passaram, logo em seguida, a efetuar as nomeações (Hill, 74-79; Nippel, 237-44).

Entretanto, o Parlamento deixou de ser um conjunto de grupos sociais coesos: uma parte da baixa nobreza, que até então apoiava a política dos líderes da Câmara dos Comuns, debandou-se para os realistas, receosa com o rumo que as reivindicações parlamentares tomara (entre eles, o visconde de Falkland e John Colepeper). Fato este que irá propiciar a guerra civil, uma vez que o rei, até então isolado em suas reivindicações, pôde assegurar para sua causa o apoio social que Ihe faltava. No final de 1641, as lideranças parlamentares dirigiram uma violenta acusação pública ao governo de Carlos I (Grand Remonstrance), cujo objetivo era voltar o povo contra o rei, e, em meados de 1642, na vigília da guerra civil, lançaram um ultimato ao rei: as Nineteen Propositions. Entre outras coisas, este documento exigia que todos os membros do Conselho Privado do rei, todos os seus ministros, todos os preceptores dos herdeiros do trono inglês, todos os altos prelados da Igreja e todos os altos oficiais do exército somente poderiam ser nomeados com a sua aprovação. Em sua propaganda, o Parlamento apontava a necessidade de medidas que evitassem que o governo de Carlos I usurpasse o Antigo Regime: desmontar o aparelho burocrático e abolir os expedientes financeiros do rei para evitar que a coroa governasse contra os interesses dos súditos; evitar que a Igreja continuasse a ser utilizada como agência de propaganda real (nesta época, os 
púlpitos eram os principais locais de divulgação de idéias); e, fundamentalmente, impedir a criação de um exército permanente controlado pelo rei, pois tornara-se evidente a intenção absolutista do rei. Na realidade, com as Proposições, mudou radicalmente, em parte devido à saída dos líderes mais moderados, o rumo das reivindicações parlamentares: paladino do Antigo Regime, até aqui, o Parlamento passou a exigir para si o controle direto e irrestrito de todas as prerrogativas do rei. Além do mais, nesta época, um número cada vez maior de parlamentares acreditava que o Parlamento, como corpo representativo do reino, poderia elaborar e por em vigor as leis que julgasse necessárias sem mesmo consultar o rei. Suas exigências, apesar de ainda estarem cobertas pelo véu da fundamental law, eram de fato revolucionárias. Assim como os Tudors, o Parlamento almejava a soberania. Um passo decisivo para a guerra civil havia sido dado, neste momento, pelo Parlamento (Nippel, 244-7).

Os acontecimentos até aqui descritos comprovam quanto as intenções dos principais atores políticos estavam distantes da literatura política da época. Apesar do recurso freqüente ao Antigo Regime, nenhuma das duas partes em conflito se preocupou em elucidá-la, em decifrar a sua forma e o seu fundamento, ou em recorrer aos que procuraram responder a esta questão. Formulada pela primeira vez, em seus escritos de 1461 a 1470, pelo jurista John Fortescue (ao retomar as considerações de Ptolomeu de Lucca acerca do regimen politicum et regale para definir a monarquia inglesa), a concepção de inspiração medieval de um governo monárquico constitucional fundado num corpo de leis imutáveis (rule of law), as leis consuetudinárias (customary laws, common laws ou laws of land), contou, na época dos Tudors, com os seus principais sistematizadores, os juristas Edward Coke, Henry Finch e John Davies - característica do reino inglês, segundo eles, desde a sua constituição, na Idade Média (Mcllwain, 87-90; Hinton, 410-11; d'Avack, 32-6). O seu impacto no desenrolar dos acontecimentos políticos foi desprezível: se não interessava ao rei, pelos limites que the impunha, tampouco esta concepção interessava ao Parlamento, pois reduzia as suas pretensões ao transformá-lo numa corte 
judiciária. Impedido de exercer as competências que havia conquistado em sua luta com a coroa, sua atividade se limitaria exclusivamente a descobrir e a declarar tais leis, sempre que o papel do rei, encarregado da sua execução, fosse colocado em dúvida. Dois fatos cruciais, entretanto, alteraram esta situação - que caminharia para a construção de um governo (popular ou monárquico) ilimitado e incontrolado, como no continente europeu: a crise política, que desembocará na guerra civil, e a Answer às Nineteen Propositions, publicadas por Carlos I, em junho de 1642.

Enquanto o Parlamento alterava o rumo de suas intenções, Carlos I, pressentindo que os desdobramentos políticos até o momento levariam inevitavelmente a uma guerra civil, assumiu repentinamente uma atitude inversa: ele renunciou publicamente, no início de 1642, o seu governo personalista, reconhecendo que havia errado, e adotou uma postura contemporizadora, abandonando o confronto diante dos avanços do Longo Parlamento, que havia caracterizado a sua atitude ao longo do ano anterior. Sob a inspiração de conselheiros ilustrados em teoria política (em particular, os ex-parlamentaristas moderados Falkland e Colepeper), uma série de documentos e declarações foi publicada pelo rei. Por um lado, no lugar de reivindicações de prerrogativas exclusivas do rei, aparecia a promessa de defender as prerrogativas próprias do Parlamento e, sobretudo, de jamais violar as leis promulgadas em conformidade com esta instância; por outro lado, toda legislação que prescindia da aprovação do rei, como a Militia Ordinance, ficava associada ao abuso de poder. Através destas publicações, a opinião pública - que começara a se formar em virtude da crescente conscientização de que uma crise política se instalara na Inglaterra -, começou a se convencer de que era o Longo Parlamento, e não o rei, o culpado pela triste situação de sua época. A mais importante entre elas, sem dúvida alguma, foi a Answer to the Nineteen Propositions (Weston, 426-7; d'Avack, 4144).

O rei baseou a sua rejeição às Proposições sob a alegação de que as duas Câmaras, em virtude dos seus avanços em 1641, já haviam adquirido os 
poderes necessários para evitar um governo arbitrário do rei. Caso vigorarem as Proposições, afirma o rei em sua Resposta, reinaria o caos, pois seria destruído o Antigo Regime, que ele define - seus conceitos ecoarão em todas as discussões políticas, nas próximas gerações - como um governo misto, composto pelos três estados que formam a sociedade inglesa (o rei, os lordes e os comuns) assentados no Parlamento, cada qual independente entre si (quanto às suas atribuições próprias) e, ao mesmo tempo, interdependente (com poderes para frear aquele que ultrapassar os limites de suas atribuições). Para dar consistência a suas afirmações, Carlos I se socorreu nos argumentos dos capítulos iniciais do Livro VI de Políbio - que retomará o prestígio perdido. Existem, continua a Resposta, três principais formas de governo: a monarquia, a aristocracia e a democracia. Cada qual representa, respectivamente, o governo de um, de poucos e de muitos. A vantagem da monarquia estaria na união da nação sob uma única pessoa, para melhor resistir às invasões externas e às insurreições internas; da aristocracia, na deliberação dos mais hábeis sobre o bem público; da democracia, na coragem e na laboriosidade, que a liberdade propicia. A desvantagem da monarquia seria sua tendência inevitável em transformar-se em tirania; da aristocracia, em facções e divisões; da democracia, em tumultos, violência e licenciosidade. A King's Constitution possuiria todas estas vantagens e evitaria estas tendências desvantajosas por ser uma mistura de monarquia, aristocracia e democracia. Nela, segue a Resposta, o rei é encarregado do governo (elabora os tratados de paz e as declarações de guerra, nomeia os ministros e juizes, concede a anistia, proclama os pares, etc.). Estes poderes the propiciam o respeito da nobreza e a reverência do povo. A Câmara dos Comuns, por sua vez, é uma excelente protetora da liberdade. Ela não participa em nenhum momento do governo, mas pode aprovar as taxas que achar necessárias, e punir com o impeachment os membros do governo (exceção ao rei) que excederem as suas atribuições. Finalmente, a Câmara dos Lordes está incumbida de ser o fiel da balança; pois, ao evitar que o peso do rei supere desmesuradamente o peso do povo e vice-versa, ela protege um do outro, mantendo-os em equilíbrio. $O$ 
governo misto, entendido desta forma, é não só a melhor forma de governo, mas a única solução para a desordem, conclui este importante documento (Weston 428-9; d'Avack 45-7).

É necessário ressaltar que, apesar da reabilitação dos clássicos da política na Inglaterra desde o século XVI, para conferir autoridade ao seu documento, Carlos I recorre não à Antigüidade, mas à própria tradição. Esta "antiga, justa, ótima, bem balanceada e jamais suficientemente louvada Constituição deste reino", informa Carlos I aos seus súditos, foi fruto "da experiência e da sabedoria dos nossos ancestrais". A primeira reação dos ingleses à crise política não foi a imitatio, como na Florença renascentista (ou seja, a inspiração nos modelos grego e romano para a solução de sua crise, em conseqüência do desprezo ao ordenamento político que Ihes sucedera), mas o retorno às suas próprias raízes. No entanto, dois pontos precisam ser esclarecidos: a tradição política inglesa a que Carlos I se refere é um mito, em cuja base está a interpretação histórica equivocada dos escritores e propagandistas da monarquia constitucional mista da era Tudor; e o seu apelo a ela, por si só, não foi determinante para o impulso que este documento tomou. Do mesmo modo que Carlos I, diversos autores, durante a dinastia Tudor, trataram o mesmo tema do mesmo modo (o que faz deles não só os primeiros teóricos do constitucionalismo como também os primeiros elaboradores do mito da monarquia mista inglesa). As afirmações que a melhor forma de governo, pela sua estabilidade e durabilidade, é o governo misto (de monarquia, aristocracia e democracia), que cada parte desta mistura é constituída por um dos três estados (o rei, os lordes e os comuns), formando o Parlamento (ou, para usar uma expressão que começa a se formar e que será, a partir da guerra civil, de uso corrente, o King-in-parliament), que a sua função é proporcionar um balanço de poder entre estes três segmentos que formam a sociedade e que este regime já existia desde o primeiro reinado inglês (o primeiro e único a desfrutar esta experiência) - além da referência a Políbio - estão presentes, embora de uma 
maneira não tão explícita e sistemática como na Resposta, em vários obras, ao longo do século XVI.

Entre as mais significativas, podemos citar as de Thomas Starkey (capelão de Henrique VIII e arguto defensor da causa do rei contra a Igreja romana), publicadas entre 1536 e 1538, de John Ponet (bispo de Winchester, sob o reinado de Eduardo $\mathrm{VI}$, foi obrigado a abandonar a Inglaterra por questões religiosas com a rainha católica Maria), de John Aylmer (bispo de Londres, teve pelo mesmo motivo o mesmo destino de seu colega), de Thomas Smith (conselheiro e embaixador da rainha Elizabete na França), Thomas Cartwright (principal líder do movimento presbiteriano no reinado de Elizabete) e do jesuíta Robert Parsons. O que fez com que estas obras, ao serem publicadas, não tivessem o menor impacto entre os ingleses (tanto no plano das idéias quanto no plano das ações) foi menos a fragilidade de seu conteúdo do que as circunstâncias na época dos Tudors - quando, com exceção das principais casas da nobreza feudal, todos se beneficiavam da sua política. Não fosse o momento de crise política pela qual atravessava a Inglaterra e a resposta a esta crise formulada pelo rei da Inglaterra, jamais haveriam estas afirmações produzido um impacto tão decisivo e duradouro, a ponto de poderem ser consideradas marco histórico da política moderna. Este é o motivo pelo qual estas obras terão repercussão somente mais tarde, quando elas serão repetidamente citadas e algumas delas reeditadas, para dar conta do aumento de interesse despertado o Shorte Treatise of Politike Power (1556), de Ponet, foi reestampado em 1639 e em 1642; o De Republica Anglorum (1583), de Smith, foi estampado somente no ano de 1640 em onze edições; e a Conference about the next Succession to the Crowne of England, de Parsons (1594), foi reeditada em 1648 (Weston, 427-8; d'Avack, 7-30).

Inicialmente, o Parlamento procurou evitar tanto a discussão quanto a repercussão da Resposta. Quando Carlos I enviou o seu documento ao Parlamento, ele, concomitantemente, ordenou a sua publicação e a sua leitura em todas as igrejas e capelas do reino. A Câmara dos Comuns, após deliberar sobre 
o seu conteúdo, respondeu ao rei com um decreto (assinado em conjunto com a Câmara dos Lordes), afirmando que as suas exigências de publicação e de leitura nas igrejas e capelas da Resposta eram contrárias às laws of lands, e nomeou uma comissão de notáveis para redigir um documento que a contestasse. Preocupado em evitar que a sua divulgação se alastrasse, o Parlamento viu os seus esforços fracassarem com o início da guerra civil - o documento de contestação jamais foi concluído, a Resposta foi publicada em seis diferentes edições (três em Londres, uma em Oxford, uma em Cambridge e outra em York) e acabou se transformando no documento central da luta ideológica, que passou a ser travada entre os realistas e os parlamentaristas, despertando na opinião pública um interesse jamais visto até então. O trauma ocasionado pela guerra civil determinou o rumo mesmo desta luta: enquanto que os realistas - com exceção de alguns poucos escritores e publicistas mais intransigentes, que ainda continuavam defendendo a desacreditada teoria do direito divino do rei acabaram por aceitar definitivamente que a teoria das prerrogativas absolutas do rei havia morrido e que era necessário abrir concessões para o Parlamento; o seu efeito sobre os parlamentaristas - com exceção dos "independentes", uma minoria que desejava a eliminação da monarquia - fez com que, pouco a pouco, eles, por sua vez, também desistissem de suas prerrogativas absolutas e acabassem por se aproximar dos realistas. Graças à guerra, a Resposta assumiu um papel central, servindo de base de argumentação para os panfletistas e teóricos de ambos os lados em conflito. É importante ressaltar que, mesmo que panfletistas e teóricos, ao elaborarem os seus escritos, se desviaram substancialmente de alguns pontos da Resposta, o mito inglês passou não só a estar presente em suas obras, como também a servir de modelo para suas reivindicações - para eles, o Antigo Regime, que deveria ser preservado, é uma mistura das formas puras de governo e dos três estados, os quais formam 0 Parlamento, onde é mantido um balanço entre as três partes através da separação das funções administrativas e do controle recíproco. Uma prova da sua aceitação é a reabilitação dos primeiros formuladores do regime misto, até então 
esquecidos, da era Tudor, que passam a ser citados abundantemente pelos dois lados em confronto (Weston, 432-3).

Durante este debate, os pontos iniciais de divergência entre os dois lados eram claros. Tomando a dianteira na luta ideológica de convencimento da opinião pública, os realistas, destacando-se Henry Ferne, Dudley Diggees, John Spelman e John Bramhall, enfatizaram o caráter monárquico do governo misto inglês com o objetivo de solucionar a guerra à sua maneira. Ao recorrer ao documento de Carlos I para sustentar que, pela tradição, o rei apesar de fazer parte do Parlamento tem atribuições soberanas, não compartilhadas com o Parlamento - elaborar tratados (de guerra, de paz ou de aliança), controlar o exército, nomear juizes e altos funcionários e convocar, adiar ou dissolver o Parlamento - os realistas acrescentaram a de guardião da constituição. Ou seja, no caso de um conflito entre o rei e as duas Câmaras, caberia a ele assumir as prerrogativas mesmas das Câmaras, uma vez que estas foram concedidas pelo rei. Já os publicistas parlamentaristas, destacando-se Charles Herle, Henry Parker e Philip Hunton, afirmaram que as atribuições do governo sempre foram compartilhadas pelos três estados, mas que, no caso de impasse entre eles, a prioridade no governo seria dada às Câmaras (d'Avack, 56 e 64-81). Pouco a pouco, estas posições iniciais - na verdade, irreconciliáveis com a doutrina de regime misto - acabaram sendo abandonadas pelas partes em confronto, à medida que o mito inglês se solidificava. Ao longo da guerra civil, realistas e parlamentaristas passaram a compartilhar as mesmas convicções centrais. A partir de então, eles não cansaram de repetir que enquanto o Antigo Regime, entendido como um regime misto, não fosse restabelecido reinaria a guerra civil, o pior de todos os males. Ou seja, a estabilidade social, propiciada pelo Antigo Regime, somente poderia continuar a existir se houvesse um sistema de pesos e contrapesos (checks-and-balances) distribuídos entre os três estados que compõem a sociedade e suficientes para impedir a usurpação de um ou dois estados sobre outro - um sistema de instâncias igualmente independentes em suas funções e estreitamente interdependentes no que diz respeito ao controle 
sobre o abuso do poder. Estas convicções, que coincidem tanto com as considerações centrais da Resposta quanto com as dos escritores da era Tudor, continuaram a ser repetidas, ao longo da guerra civil, em inúmeras publicações e sermões dominicais, repercutindo inevitavelmente na formação da opinião pública.

Mesmo os acontecimentos que marcaram a vida política da Inglaterra após os debates da guerra civil - a derrota dos realistas, o recomeço da guerra civil, a execução de Carlos I e a ascensão de Cromwell -, longe de abalarem o mito inglês, acabaram contribuindo, apesar de alguns percalços, para a sua aceitação geral. A primeira impressão que estes acontecimentos nos causam é de que a doutrina do governo misto fenecia. O Parlamento - cuja fraqueza no confronto com as tropas realistas se devia à organização do seu exército nos moldes dos realistas (centrando as suas forças na cavalaria, composta pela baixa nobreza ainda leal à sua liderança), à ausência de coordenação militar (de um lado, havia os "presbiterianos", partidários da monarquia mista; de outro, os "independentes", defensores da soberania parlamentar e da abolição da monarquia) e à falta de recursos (só mais tarde o Parlamento taxará aqueles que até então eram taxados pela coroa) - só pôde vencer a guerra civil quando passou a contar com o talento de Oliver Cromwell, que remodelou o exército de uma forma revolucionária para a época. Com ele nasceu o Novo Exército Modelo, onde a espinha dorsal era formada pelos "cabeças redondas" (pequenos proprietários rurais puritanos, que, ao contrário dos nobres, tinham o cabelo curto), a carreira era dada pelo mérito, e não pelo nascimento, e a organização e o financiamento eram nacionais. Devidamente organizado, pago com regularidade e consciente de sua missão (Cromwell não só permitia, como também incentivava as reuniões e discussões), o Novo Exército pôde chegar a seu intento, derrotando as tropas realistas, em 1645, e obrigando Carlos I a se render ao exército escocês, que o negociou com o Parlamento inglês. Daí em diante, facções no Novo Exército, que passou a ter um papel político de destaque, e no Parlamento tornaram-se mais ativas. Os levellers, 
partidários de uma democratização política e social, aumentavam consideravelmente a sua influência no exército - chegando mesmo a criar o Conselho do Exército, cujo objetivo principal era dominar esta instituição com o objetivo de implantar as suas reformas radicais. Entretanto, os "presbiterianos" começaram a negociar com o rei no cativeiro - sua proposta era livrar-se do exército vitorioso, enviando-o à reconquista da Irlanda, a fim de restituir Carlos I. Em julho de 1647, após descobrir este plano, o Novo Exército (com a conivência de Cromwell e de seu genro, Henry Ireton, que até então eram convictos defensores do regime misto de Carlos I) capturou o rei. Forçados pelo Novo Exército, os "presbiterianos", que formavam a maioria da Câmara dos Comuns, foram obrigados a se afastar, deixando o Parlamento nas mãos dos seus aliados, os "independentes" remanescentes (o Rump Parliament). Enquanto isso, o rei fugiu da prisão, a guerra civil recomeçou em maio do ano seguinte e Cromwell foi reconduzido à frente do Novo Exército. Após a derrota das tropas realistas, por pressão do Rump Parliament e do Novo Exército, o rei foi executado (janeiro de 1649) e a monarquia e a Câmara dos Lordes (que se recusou a aprovar o julgamento do rei, sob a alegação de que, pelas leis fundamentais da Inglaterra, sem o rei não pode existir Parlamento) foram abolidas. Em maio deste ano, foi proclamada a República, na qual os comuns remanescentes reivindicavam para si todos os poderes (Hill, 86-97).

Apesar destes reveses, a popularidade e a aceitação do mito da monarquia mista inglesa jamais esmoreceram. Pelo contrário: a sua vitalidade na opinião pública e no pensamento político, neste último período, é testemunhada nos debates parlamentares e nos panfletos divulgados na imprensa e lidos nos púlpitos, onde agora passa a ser destacado que o Antigo Regime seria uma garantia não só contra a tirania do rei, como também contra a anarquia popular desfecho inevitável no caso de um governo dos "independentes" ou de uma democracia dos levellers. Uma outra prova da sua popularidade e aceitação geral encontramos no testemunho daqueles que denunciaram esta interpretação mítica do passado. Robert Filmer, em sua Anarchy of a Limited or Mixed Monarchy, 
publicada em 1648, afirma em tom polêmico que a grande maioria dos ingleses estava convencida "que o governo do reino da Inglaterra é uma monarquia limitada e mista... e que isto não é surpreendente, pois todas as discussões e debates deste tempo confuso, tanto na imprensa quanto no púlpito, acabavam com esta conclusão". Thomas Hobbes, no seu Leviatã (1651), atribui a causa da guerra civil à ampla aceitação da concepção de que a Inglaterra era uma monarquia mista - "todo o país estava aficionado por esta fórmula". Isto comprova o quanto o exército, o Rump Parliament e a República eram impopulares, nesta nação tomada de orgulho pela monarquia mista (Weston, 437 e 440).

No poder, as ações iniciais de Cromwell visaram desviar a Inglaterra deste rumo. Na década de cinqüenta, ele já tinha o controle definitivo do exército que ajudara a criar - depois de eliminar os principais chefes levellers, que, como ele, disputavam o seu controle - e se voltava sucessivamente para o Parlamento. Entretanto, várias medidas importantes foram tomadas sem que houvesse qualquer dissensão. A Irlanda foi reconquistada e suas terras foram expropriadas de seus proprietários e vendidas para a baixa nobreza e a burguesia nascente inglesas. Ao mesmo tempo, foram confiscadas e vendidas as terras da coroa, as que ainda restavam nas mãos da Igreja e de muitos dos principais realistas. Com isso, o governo de Cromwell obteve recursos para as suas diversas atividades, propiciou terras aos segmentos sociais que mais cresciam economicamente e enfraqueceu definitivamente seus oponentes da nobreza que, além do mais, tiveram as suas fortalezas medievais destruídas, foram desarmados e obrigados a pagar uma taxa, que levou muitos dos que ainda mantinham grandes propriedades de terras a vendê-las para saldarem as suas dívidas. Em 1653, Cromwell dissolveu o Parlamento e convocou em seguida outro formado pelos seus partidários mais próximos (Barebones Parliament), que o proclamou Lorde Protetor. Pressionado, Cromwell preparou, neste mesmo ano, um novo projeto constitucional, o Instrument of Government, onde seria instituído um regime misto desvinculado dos três estados - formariam as suas três instâncias de governo o Lorde Protetor (Cromwell), um Conselho e os Comuns. 
Seu propósito, ele afirmou perante o Parlamento, seria "evitar os extremos da monarquia e da democracia" (Friedrich, 200). Mesmo assim, continuaram as disputas entre o Parlamento e Cromwell, que o dissolveu, governando exclusivamente com o apoio do exército.

Entretanto, a crise política que se instaurou na Inglaterra entre 1640-60 e que gerou os debates a que nos referimos acima, não teve como única referência o modelo constitucionalista. Além do conservador Filmer e do teórico da monarquia absoluta Hobbes, outro autor que passou a exercer influência nos debates subseqüentes e que trouxe a melhor contribuição para desmascaramento do mito inglês, foi o republicano James Harrington. A sua reação à crise foi a mesma de Bruni: em sua Oceana, publicada em Londres, em 1656, a história da Inglaterra é reinterpretada criticamente e, dentro da tradição renascentista da imitatio, as repúblicas antigas e a de Veneza - na verdade, a Veneza mítica dos humanistas cívicos do Renascimento italiano - são tomadas como modelo. Certamente, a Sereníssima sempre gozou de um certo prestígio na Inglaterra. Desde a sua publicação original, as obras de Guicciardini, Giannotti, Contarini e Paruta circulavam por toda Inglaterra, durante os séculos XVI e XVII. Várias obras foram traduzidas para o inglês, entre as principais: Historie (1579), de Guicciardini; The commonwealth and government of Venice (1599) de Contarini (por Lewes Lewkenor, que, em suas notas, além de trazer extratos de outros autores do Renascimento italiano, em particular, Giannotti, expressa com forte eloqüência a sua admiração por Veneza); The generall historie of the magnificent state of Venice (1612), de Thomas de Fougasses; The history of Venice (1658) de Paruta. Em 1644, um grupo de líderes parlamentares convocou o embaixador veneziano para descrever detalhadamente a constituição de sua cidade, no intuito de entender o motivo de sua fama. As peças de Shakespeare, O Mercador de Veneza e Otelo, na virada do século, e os relatos de viagem, como o Itinerary contayning a voyage made through Italy in the years 1646 and 1647 (1648), trazem considerações elogiosas às instituições políticas de Veneza. James Howell, o mais persistente admirador da Veneza de Contarini, escreveu três 
panegíricos ao longo de dez anos - Instructions for forraine travell (1642), Dodona's grove (1644) e Survay of the signorie of Venice, of her admired policy and method of government (1651) -, onde ela é elogiada pela perfeição de sua constituição, que lhe permite, graças à mistura dos três elementos que formam as constituições simples, resistir às agruras do tempo, e ao mesmo tempo é sugerida como modelo de imitação para os ingleses, cansados de tantos anos de instabilidade política. A admiração por Veneza pode ser também medida pelos seus críticos. Em 1647, surge um panfleto, $A$ parallel of governments: or a political discourse upon seven positions, onde a preocupação central é combater o entusiasmo reinante por Veneza. No final do ano seguinte, o realista John Laurens critica os que procuram reduzir as atividades do rei inglês às do doge veneziano. Procurando atacar a reputação que Veneza gozava em sua época, Robert Filmer, em suas Observations upon Aristotle's Politiques, publicadas em 1652, afirma, entre tantas coisas, que ela deve a sua duração à sua localização, e não à sua constituição; que esta jamais foi, como quis Contarini, uma mistura de monarquia, aristocracia e democracia; que, originalmente, Veneza foi uma oligarquia (de mercadores), e que, com a ascensão dos doges, tornou-se uma monarquia absoluta, motivo pelo qual obteve os seus maiores avanços; e que hoje ela é uma aristocracia (de patrícios) desmesuradamente opressora, a ponto da maioria dos venezianos preferir viver sob os turcos (Fink, 42-9).

No entanto, a crescente admiração dos ingleses pelo mito veneziano, ao longo dos séculos $\mathrm{XVI}$ e XVII, não entrou em conflito com a formação do mito inglês. Pelo contrário, quanto mais se agravava a crise política, quanto mais avançava a convicção da necessidade de se retomar o Antigo Regime para por fim a esta crise, tanto menos a distinção entre uma república mista e uma monarquia constitucional mista tornava-se evidente. Assim, do mesmo modo que no plano teórico a Veneza de Giannotti, Contarini e Paruta acaba se reduzindo ao ideal constitucional inglês, como observamos nas obras de Howell - o primeiro autor de destaque a interpretar a constituição veneziana como um bem-sucedido sistema de pesos e contrapesos entre o elemento monárquico, 
aristocrático e democrático, cujo objetivo único é propiciar a liberdade da opressão política -, surgem várias manifestações, tanto da parte dos realistas quanto dos parlamentaristas, de que, entre todos os reinados, os reis da Inglaterra (isto é, aqueles que teriam regido em conformidade com o Antigo Regime) são os que mais se assemelham com os doges venezianos. Coube a Harrington, apoiado numa interpretação mais adequada destes autores do Renascimento italiano, desfazer a confusão entre o governo misto republicano e o constitucional. (Esta confusão está presente entre aqueles historiadores do constitucionalismo, citados na Introdução, que procuraram estabelecer, sem qualquer distinção, uma linhagem direta entre todos os teóricos do governo misto: iniciando com Políbio e passando pelos italianos dos séculos XV e XVI - às vezes incluindo Tomás Aquino e Ptolomeu de Lucca -, pelos ingleses dos séculos XVI e XVII e por Harrington).

Em sua Oceana, ao retomar a classificação clássica das seis formas puras de governo, Harrington introduz novos elementos para torná-la mais completa e mais adequada aos seus propósitos - desmascarar o mito da monarquia mista inglesa e a doutrina da monarquia absoluta de Hobbes. Para ele, a durabilidade de um governo está ligada à maneira como a infra-estrutura econômica (o "fundamento", a distribuição natural das terras numa comunidade) e a superestrutura política (as "ordens", a distribuição do poder, isto é, das funções e dos cargos públicos) se ajustam mutuamente. A primeira é obra da fortuna, enquanto que a segunda é obra do legislador (51). A posse da terra dá autonomia para o seu proprietário e poder sobre aqueles que dependem da sua posse para se alimentar (seus dependentes); a maneira como ela é distribuída numa comunidade determina aquilo que Harrington chama "equilíbrio do poder". Para que um governo seja durável ele deve contar com a prudência do legislador, isto é, com a sua habilidade de criar superestruturas de governo que se adeqüem aos fundamentos propiciados pela fortuna (101). Sempre que uma superestrutura política tiver como base uma infra-estrutura econômica equivalente, o governo é natural. Assim, três são as formas de governo natural: a monarquia absoluta, 
onde um único homem possui todas as terras (como no Império Turco, exemplo de perfeição em sua espécie) ou a maior parte delas (como no Império Romano, cujo governo é, portanto, menos natural); a monarquia mista, onde poucos possuem todas as terras (como na Inglaterra medieval, antes da reforma agrária dos Tudors, exemplo de perfeição em sua espécie) ou pelo menos a maior parte delas; e a república, onde todos possuem eqüitativamente todas as terras (como Esparta) ou a maioria possui a maior parte das terras. Por outro lado, se a distribuição das terras não corresponder a uma forma de governo adequada, três formas de governo violentas e extremamente instáveis podem surgir: a tirania, quando um governa sem possuir todas as terras ou a sua maior parte; a oligarquia, quando alguns governam sem possuir todas ou a maior parte das terras; e a anarquia, quando os muitos governam sem possuir todas ou a maior parte das terras. Existe uma situação intermediária de equilíbrio de poder cujas conseqüências são ainda mais violentas, embora não extremamente instáveis como a anterior: quando poucos têm metade das posses e os muitos outra metade, as duas partes lutam desesperadamente para impor o seu governo sobre a outra (é o que explica as constantes lutas em Atenas, que originavam ora um governo de poucos ora um governo de muitos); o mesmo ocorrendo quando um só detém a metade das posses e os muitos a outra metade (como a longa e cruel luta que antecedeu a solidificação do Império, quando os imperadores romanos, calcados em suas posses nas províncias, onde estavam assentados os colonos militares, se voltaram contra o povo e seus senadores) (53-4).

No entanto, o governo natural não necessariamente é perfeito, isto é, imortal. A adequação da forma de governo à maneira como as terras estão distribuídas é a condição necessária para a sua durabilidade (54), mas não é suficiente para que ela possa evitar uma revolução. Retomando a célebre passagem da Política de Aristóteles (Pol. 1309 b 16), Harrington afirma que "a perfeição de um governo só é alcançada quando ninguém dos que estão submetidos a ele tem interesse em alterá-lo, ou os que têm interesse não têm poder para derrubá-lo" (72). Assim, as monarquias naturais, que chegaram à 
perfeição em sua espécie, não alcançaram a perfeição quanto à forma de governo. Na monarquia absoluta turca, o povo, embora não tenha a força, tem interesse em destituir o governo, enquanto que os janízaros (a guarda pessoal do monarca, a base armada do seu poder sobre o povo) têm freqüentemente o interesse e constantemente a força para derrubá-lo, embora não queiram mudar a forma de governo. O monarca e a sua guarda estão constantemente em luta e não podem contar com o apoio do povo para a sua causa. Na monarquia mista inglesa, do mesmo modo, o povo, embora não tinha a força, tinha interesse em alterar a forma de governo, enquanto que a nobreza (base de sustentação do poder do monarca sobre o povo, que em troca de terras prestam serviço militar ao rei) tinha freqüentemente $o$ interesse e constantemente a força para derrubar 0 rei, embora não pretendesse alterar a forma de governo. O rei estava constantemente em disputa com a nobreza, e, não podendo se apoiar no povo, teve que contar com a animosidade natural entre as principais casas da nobreza feudal para se manter no poder. Longe de haver um equilíbrio de interesses, a monarquia mista inglesa foi marcada por um conflito desestabilizador entre os três estados. Harrington, assim como Aristóteles e Políbio, não acredita na concepção de que a estabilidade política possa ser obtida através de um balanço institucional de interesses conflitantes; para eles, o que conta para que se possa alcançá-la é a eliminação do conflito. É por este motivo que Esparta não conheceu sedições (ao menos enquanto valeu a lei agrária de Licurgo), o mesmo acontecendo com Veneza no presente, pois a grande maioria tem interesse em mantê-la (72-3).

Seguindo as considerações de Aristóteles, Harrington afirma que enquanto nas formas imperfeitas de governo reina o interesse das partes ("a causa de todos os infortúnios"), na república (commonwealth) reina o interesse público, ou seja, "cada qual se sente obrigado a promover o bem dos outros e todos se sentem obrigados a preferir o bem comum a um bem particular" (62). Portanto, as monarquias absoluta e mista por levarem em consideração exclusivamente $\mathrm{o}$ interesse de um só e de poucos, respectivamente, são imperfeitas, pois geram a discórdia e, conseqüentemente, as facções, com as 
quais nenhum governo pode pretender ser estável; enquanto que o regime perfeito só é alcançado com a harmonia, através da disposição de cada um de seus cidadãos de preferir o bem de todos ao seu próprio bem. Para Harrington esta é a sua inovação para com Aristóteles e Políbio -, sem uma superestrutura, entendida como um arranjo institucional que obrigue a todos seguir o interesse público mesmo com sacrifício do interesse privado, não pode haver um governo estável. É este o significado de seu lema: "dê-nos bons ordenamentos e estes nos darão bons homens" (105). Assim, o que leva um governo a durar eternamente é dispor de uma distribuição de terras sob a qual seja possível fundar uma superestrutura que faça com que os homens naturais, "criaturas impulsionadas pelo proveito próprio" (62), se transformem em bons homens, isto é, que faça com que cada homem seja levado a perseguir o bem dos outros ao invés do seu próprio bem. A concepção de uma superestrutura que propicie um governo imortal Harrington acredita encontrar pela primeira vez nos intérpretes renascentistas da constituição de Veneza.

Tomando como base as descrições de Giannotti, Contarini e Paruta sobre o funcionamento da constituição veneziana, Harrington afirma que uma superestrutura perfeita deve ser composta, em primeiro lugar, de um governo misto, ou seja, de um Senado e uma Assembléia do Povo, cujas funções são distintas: aquele delibera e propõe e esta decide (66). A justificativa para esta separação das funções é oferecida com base em dois exemplos singelos. Para que haja uma partilha justa de uma torta entre duas garotas, convém que uma divida a torta e a outra escolha - esta divisão de funções impede que uma tire proveito da outra. Num outro exemplo, Harrington afirma que se tomarmos vinte pessoas, pelo menos seis se destacarão das outras, de modo que naturalmente serão consultadas pelas quatorze antes de tomarem qualquer decisão. No seio de uma comunidade política aqueles que se destacam pela sua qualidade cívica sua "virtude ou autoridade" - devem constituir uma instituição independente, cujo propósito único é deliberar sobre o que deve ser seguido; ao passo que o restante da população deve decidir - independentemente, mas com base nas reflexões da 
primeira instituição - entre as propostas apresentadas. O Senado (o elemento aristocrático da constituição, composto não por aqueles que possuem privilégios hereditários, com os quais nenhuma república pode contar se quiser ser estável; mas por uma aristocracia natural, por aqueles que pela sua virtude e pela autoridade que exercem sobre o povo são "a verdadeira vida e alma" da república) divide - isto é, pesa as razões de uma alternativa contra outra - e a assembléia popular (o elemento democrático, representando os interesses do povo) escolhe - não de maneira arbitrária, mas considerando as ponderações dos senadores. (Harrington cita um terceiro órgão, a Magistratura, cuja função seria executar o que foi escolhido, representando o elemento monárquico, mas que desempenha um papel desprezível dentro da sua concepção de governo misto, e que pode ser entendido mais como uma deferência aos autores italianos, nos quais ele se inspira, e ao doge veneziano). Deste modo, a população acaba sempre seguindo o interesse público (63-4). Um Senado que discute e decide é uma oligarquia, e toda oligarquia é facciosa (como em Roma, na época dos irmãos Gracos); uma assembléia que não pauta as suas decisões pelo conselho de uma aristocracia natural vive a perpétua turbulência das facções (como em Atenas, no passado, e a Inglaterra, em 1649, quando o Parlamento, "investiu-se do poder total para governar... sem ordenamento de nenhuma espécie") (105-7). Mas isto não é tudo. Com base nestes mesmos autores italianos, o humanista inglês afirma que, para esta divisão proporcionar o efeito esperado, esta superestrutura deve ser composta, em segundo lugar, de eleições secretas com rodízio dos cargos públicos. A eleição (que deve ser secreta, para evitar intimidações ou corrupção, e aberta a todos os cidadãos, para evitar qualquer privilégio) permite, na visão de Harrington, selecionar aqueles que mais se destacaram pela virtude cívica, para as funções deliberativas do Senado, e aqueles que são mais aptos a decidir pela população, para a Assembléia; e é complementada pelo rodízio, que, além de evitar a corrupção e o abuso do poder, permite a extensão da participação direta ao corpo dos cidadãos (75). Assim, esta é a interpretação harringtoniana do mito veneziano, a superestrutura política da 
Sereníssima teria um duplo propósito: promover tanto a virtude política, mediante a separação entre deliberação e decisão e a eleição, quanto a igualdade política, mediante a abertura dos cargos públicos a todos os cidadãos e o rodízio.

Concluindo: sem que os membros de uma comunidade sejam virtuosos, isto é, sem que estejam dispostos a preferir o bem comum ao bem próprio, esta não pode constituir um governo estável; tal disposição, porém, só surge através de uma superestrutura (assim como foi delineada no parágrafo acima); por sua vez, ela precisa estar assentada numa distribuição eqüitativa das propriedades fundiárias (que garanta a autonomia econômica e militar de seus membros) para realizar tal objetivo. Estas considerações acerca do governo perfeito, que Harrington chama "república eqüitativa" (equal commonwealth) uma república de iguais, "pois mantém a igualdade tanto em seus fundamentos como em sua superestrutura" (74) -, permite ao autor compará-la com as experiências republicanas, do presente e do passado, e apontar algumas de suas falhas. Assim, Veneza - Harrington cita como referência para as suas conclusões, neste ponto, Giannotti - é menos perfeita em suas leis "não tão claras e efetivas" referentes ao fundamento (não contando com uma distribuição eqüitativa entre os cidadãos, Veneza viu-se dividida entre patrícios e plebeus, e, além do mais, obrigada a recorrer aos mercenários, impedida que estava de formar uma milícia de cidadãos armados e independentes) e mais perfeita em sua superestrutura (embora não totalmente, pois "o rodízio nas principais magistraturas está nas mãos de poucos"). Esparta foi mais eqüitativa na sua infra-estrutura (a lei agrária de Licurgo proporcionava uma igual distribuição de terras a todos), embora menos em sua superestrutura (não havia rotação entre os principais cargos: os reis eram hereditários e os senadores, embora eleitos pelo povo, eram vitalícios). Roma, por sua vez, não foi eqüitativa em sua lei agrária (devido ao fracasso dos projetos iniciais de redistribuição das terras dos irmãos Gracos, os primeiros, em Roma, a compreenderem a necessidade de adequação dos fundamentos para o bom funcionamento da superestrutura) nem tampouco eqüitativa em sua rotação de cargos (apesar da plebe ter obtido o acesso às magistraturas, o rodízio nestas 
continuava preponderantemente nas mãos do patriciado, pois, por conta da ausência de uma lei agrária, diminuía acentuadamente o número de proprietários rurais que não pertenciam à nobreza, ao mesmo tempo em que aumentavam os proletários na cidade, que, por não serem auto-suficientes, não podiam assumir os cargos públicos) (75-6 e 78-9).

Do mesmo modo, estas considerações de Harrington acerca do governo perfeito permite-nos compará-lo com as dos teóricos do republicanismo que o precederam e apontar as suas diferenças (e eventuais fraquezas). Com relação aos fundamentos, ao contrário de Políbio, de Bruni e dos intérpretes humanistas renascentistas da constituição da Veneza, que não levam em consideração a importância da distribuição eqüitativa das terras como a base material de sustentação da forma de governo republicano, suas considerações se aproximam das de Aristóteles sobre a distribuição desigual das riquezas como a origem de todas as revoluções (Pol. 1266 a 38-39) e, portanto, sobre a necessidade da formação de uma classe média armada de proprietários agrícolas - cujo objetivo é, como Aristóteles define o oikos, proporcionar a independência econômica (entendida não como proveito, mas como ócio para a participação política) e militar dos membros que formam a comunidade -, a espinha dorsal da república (Pocock, 1975, 390; Cotton, 379 e 381). Enquanto que o inglês enfatiza exclusivamente a autonomia econômica; para o estagirita, a posse também propicia ao cidadão o uso solidário do seu fruto, isto é, da riqueza. Entretanto, ao contrário do estagirita, que acredita na liberalidade dos ricos (e virtuosos) para a sua constituição, para o humanista inglês, o surgimento de uma classe média é obra da fortuna. Com relação à superestrutura, duas considerações devem ser feitas. Em primeiro lugar, Harrington se aproxima de Aristóteles e de Bruni ao enfatizar a igualdade política como um dos elementos constituintes da república. Mesmo não concordando com o sorteio dos cargos, a eleição dos cargos e o rodízio (determinado pela sua curta duração, pela multiplicidade das funções e pela não reeleição), visam estender a virtude cívica entre os materialmente iguais. Este é o motivo que o distancia de Políbio e dos intérpretes renascentistas da 
constituição de Veneza. Enquanto o primeiro entende a superestrutura como um sistema de pesos e contrapesos, desprezando o rodízio e pouco se importando se estes são distribuídos discriminadamente entre as distintas classes sociais, como em Roma, ou de uma maneira não discriminatória dentro de uma comunidade homogênea, como em Esparta; os últimos entendem que uma superestrutura só pode preservar a virtude cívica banindo a igualdade política e reservando os principais cargos públicos para uma classe social privilegiada - ou seja, numa república os virtuosos (os nobres e os ricos) governam o povo, que, por sua vez, aceita a condição de ser governado para o seu próprio bem.

Em segundo lugar, este é o seu calcanhar-de-aquiles, Harrington, conforme a sua interpretação dos teóricos renascentistas do século $\mathrm{XVI}$, acredita que são os bons ordenamentos que fazem os bons homens, ou seja, que a separação institucional entre a deliberação e a decisão, além da eleição, promovem mecanicamente a virtude cívica - pelas virtudes do ordenamento, os poucos saberão deliberar sobre o bem comum e os muitos saberão decidir sobre o bem comum. Neste sentido, ele se distancia de Aristóteles, que coloca o bom governo exclusivamente na dependência dos bons homens - reduzindo a superestrutura ao rodízio dos cargos por sorteio, a sua pretensão é a de que as relações de amizade possam se estender para a esfera política. Pelo mesmo motivo, ele se distancia de Políbio, para quem são os preceitos cívicos, os espetáculos cívicos e a religião cívica que induzem os homens a se sacrificarem pela pátria, enquanto que $o$ arranjo constitucional que distribui os cargos e as funções do governo, a superestrutura propriamente dita, é entendida como um sistema de pesos e contrapesos, como um governo misto, cujo objetivo é, exclusivamente, evitar o abuso de poder (visto que, apesar do importante papel desempenhado pelos preceitos, pelos espetáculos e pela religião, estes não evitam totalmente que aqueles que venham assumir os cargos públicos possam corromper-se). Do mesmo modo, ele se distancia de Bruni, para quem - é o que o motiva a rever a história de Roma e a criar a história mítica de Florença - é a educação, com base nos relatos eloqüentes do passado, que forma a 
personalidade cívica de um povo e mantém as suas instituições. Ainda com relação à superestrutura, o que separa o republicano inglês daqueles que the antecederam é a sua ênfase na fundação, na necessidade das "ordens" serem elaboradas por um único legislador de uma única vez, como fizera Licurgo (1078). A principal figura da república é o legislador (ou legisladores), o seu fundador (ou fundadores), a quem é conferido a tarefa, por se destacar dos outros pelos "dons do entendimento" (51), de elaborar a superestrutura (as ordens) que, independentemente da propensão natural dos homens a agirem para o próprio bem, farão com que estes sigam o bem comum. Apesar destas diferenças, o que une Harrington aos teóricos republicanos que o precederam, é a concepção de que um governo duradouro, que evite as revoluções, só é possível à medida que reine o consensus omnium, a unanimidade entre todos os cidadãos - cujo pressuposto básico é a disposição a sacrificar o interesse particular em prol do bem comum. É exatamente esta concepção que os afasta dos teóricos do constitucionalismo, que acreditam que as facções podem ser administradas por um sistema de checks-and-balances, o qual traria, por si só, a paz social e, conseqüentemente, a estabilidade política. A crítica de Harrington a estes (em sua época, os defensores da monarquia mista) é contundente, como veremos abaixo.

Após estas considerações acerca do governo perfeito, Harrington inicia a descrição "do começo, do progresso e do declínio da moderna prudência" - momento em que Harrington empreende a sua revisão da história da Inglaterra. A prudência moderna nasce com o Império Romano, através das armas de César; ela só foi possível "pela negligência cometida pelos romanos em suas leis agrárias", a tal ponto que quando os Gracos tomaram ciência deste problema, era demasiado tarde, pois "o equilíbrio da República já estava desfeito" (84). Como vimos acima, no momento em que os Gracos quiseram empreender a reforma agrária, a desigualdade das posses tinha se agravado à medida que as terras conquistadas dos inimigos e declaradas públicas, ao invés de serem distribuídas ao proletariado nascente (os antigos proprietários agrícolas armados, que, após as contínuas lutas, não se adaptavam mais à vida no campo), tinham caído nas 
mãos dos mesmos patrícios que pouco antes haviam comprado suas posses um momento em que o número de plebeus com disponibilidade de participar do governo diminuía, ao mesmo tempo em que os senadores passaram a agir como agentes dos interesses fundiários do patriciado. Enfraquecida a República em seu fundamento, o Império começa, na análise de Harrington, a reforçar a sua base material através do que ficou conhecido como milites beneficiarii: as terras conquistadas dos inimigos foram distribuídas aos legionários, aos quais foi outorgado vitaliciamente o seu usufruto, na condição de deverem obediência ao imperador. A estes beneficiados somou-se, para a sua proteção pessoal - mas que por vezes tornaram-se os seus carrascos -, cerca de oito mil soldados que formaram a guarda pretoriana (85).

Tal foi a transição da República para o Império, que marca o início da prudência moderna - a habilidade segundo a qual um homem ou umas poucas famílias governam os outros em conformidade com os seus interesses privados. O seu apogeu deu-se na dissolução mesma do Império Romano, empreendida pelas sucessivas inundações dos hunos, godos, vândalos, lombardos e saxões, quando ela se estendeu por todo o ocidente, salvo em Veneza, devido à sua situação inexpugnável (49-50). Sua base material é o feudum, a "posse de terras conquistadas, distribuídas pelo vencedor aos capitães e soldados seus que se destacaram em combate, na condição de reconhecê-lo como seu senhor e a si mesmos como seus súditos" (87). Na sua Inglaterra, após a conquista dos normandos, estes súditos constituíam, grosso modo, duas classes: a alta nobreza, os pares do rei, a quem foi concedida originalmente por Guilherme, o Conquistador, um feudo como gratificação pela conquista; os vassalos, a quem foi conferido pelos que pertenciam à primeira classe, com autorização do rei, fossem nobres ou não, feudos, obrigando-os a deveres militares para com seus superiores. $O$ fundamento desta monarquia consistia em cerca de sessenta mil homens a serviço do rei, baseados em sessenta mil feudos, mas que constituíam a posse de duzentos e cinqüenta senhores. Este foi o equilíbrio gótico (gothick ballance) de poder que caracterizou o seu país - assim como os reinos do mundo 
cristão de então, como o Sacro Império Romano-Germânico, as monarquias da França, da Espanha e da Polônia. Ele deu sustentação a um "governo de poucos, ou seja, da nobreza" - uma vez que quem detém a posse da terra tem o controle das armas, o poder do rei está condicionado ao apoio da alta nobreza. Harrington inverte o juízo corrente sobre o Antigo Regime: sob o manto do governo misto definido como um sistema equilíbrio de poder entre o rei, a alta nobreza (espiritual e temporal) e o povo, que formam o Parlamento -, a monarquia inglesa era, na verdade, uma forma de governo onde o trono era sustentado pela alta nobreza (o poder preponderante, em cujas mãos estava a posse das terras daqueles que se armavam); enquanto que ao povo era facultado reunir-se em assembléia, "mas que não podia pretender mais do que o seu nome sugere", por conta dos laços de dependência dos seus membros para com os seus senhores (93). Mais uma vez uma aproximação entre as análises de Harrington e de Aristóteles (como detalhamos acima, nas páginas 20 e 21) torna-se inevitável: a utilização de expedientes para a conservação temporária de formas de governo imperfeitas, expedientes que visam prorrogar, mas que não podem evitar a sua decadência. $A$ prudência moderna deve ser entendida como a habilidade, ou melhor, a astúcia do legislador para excluir uma parte da população (no caso, os muitos) do governo, mantendo a aparência de igualdade política, a aparência de que todos participam igualmente das decisões públicas. Esta superestrutura, no entanto, não evitou o conflito de interesses entre as duas outras partes: o rei, exigindo dos grandes senhores feudais as obrigações que the eram devidas, e estes retrucando aquele, dizendo-se também detentores de direitos e privilégios (94).

A dissolução da monarquia inglesa inicia-se quando os reis, insatisfeitos com a sua dependência do Parlamento e obstinados em construir uma monarquia absoluta, alteraram, sem medir as conseqüências, a natureza do seu fundamento (93). Conforme a prudência dos modernos, "sem nobreza ou exército não pode haver monarquia" (97); portanto, a constituição de uma monarquia absoluta natural deveria ter como fundamento a posse das terras (senão de todas, ao menos da maior parte), para que a concessão do seu uso 
tivesse como contrapartida a prestação obrigatória de serviços militares. Foi o que fizeram os imperadores romanos: conquistaram territórios inimigos para instalar os seus soldados (as "colônias militares") e, assim, desestabilizar o Senado, onde tinham assento os patrícios, que detinham, até então, a maior parte das terras. No entanto, os reis ingleses não deram os passos necessários para a consolidação de uma monarquia absoluta. Henrique VII, contando com a luta entre as duas facções em que se dividia a alta nobreza, confiscou as terras da Igreja, vendendoas para aqueles que formavam o terceiro estado (o povo, como chama Harrington), e, conseqüentemente, livrando-os das obrigações de vassalagem. Seus sucessores, Henrique VIII e Elizabete, ampliaram a sua política, sem darem conta, entretanto, de que ao enfraquecer a alta nobreza - que não combatia a monarquia, sem o qual não poderia viver, mas os reis que a ameaçavam -, eles estavam fortalecendo o povo - que de aliados dos reis, enquanto se beneficiavam de sua política, se transformariam, uma vez conscientes de sua força, na principal ameaça à monarquia (95). Fracassada a tentativa de construir um exército nacional dependente da coroa, fundamento natural de uma monarquia absoluta, Carlos I encabeçou - através da sua Resposta, uma obra prima da moderna prudência (Pocock, 1975, 388) -, e a sociedade inglesa endossou, o retorno da superestrutura que existia na origem, a monarquia mista, sem que fosse, no entanto, levado em consideração que o fundamento que lhe dava sustentação, o equilíbrio gótico, não mais existia. Neste momento, o restabelecimento da monarquia mista traria a instabilidade e a guerra - pois o povo seria ao mesmo tempo a parte menos interessada em manter esta forma de governo (já que, de fato, ele é excluído do governo) e a mais forte (uma vez que os Tudors transformaram os vassalos em homens armados e politicamente independentes). Se a fortuna foi atroz para esta forma de governo, em nenhum momento ela foi tão favorável à república. Basta surgir um legislador que introduza a lei agrária, fixando para as gerações futuras o "equilíbrio popular", e a superestrutura, instituindo, no lugar da exclusão política, um "governo popular" - pois onde todos 
possuem as mesmas riquezas, têm de haver uma "plena e eqüitativa" participação de todos no governo (103).

Harrington escreve sua obra para Cromwell, quando ele havia dissolvido o Parlamento e governava com o apoio exclusivo do exército. $\mathrm{O}$ autor conclama o general a seguir o exemplo do mítico legislador de Oceana, "o incomparável patriota Olphaus Megaletor". Este exímio conhecedor da prudência dos antigos, comovido que estava pela miséria de seu país, rememorou a seguinte passagem de Maquiavel: "Três vezes abençoado é o povo que tem a fortuna de contar com um homem capaz de dar-Ihe de uma só vez tal governo, que sem alteração possa assegurar-lhe suas liberdades - como acorreu com os lacedemônios, que, observando as leis de Licurgo, viveram cerca de oitocentos anos sem tumulto e sem corrupção". Tomado por estas palavras, chegou a duas conclusões: que a república deve ser obra de um único legislador e que nela o governo deve ser de todos e, além do mais, unânime. Visto que, assim como uma obra só pode atingir a sua perfeição se teve um único arquiteto, uma república bem ordenada deve ser feita de uma vez, é justo que um sábio legislador, movido não pelo interesse privado, mas pelo interesse público, pensando não em suas vantagens, mas nas de seu país, requeira para si o poder soberano para fundar a república. Ele não pode confiar em seus cidadãos, pois sabe da importância do bom ordenamento para que os cidadãos possam adquirir bons hábitos, e da dificuldade intransponível que Roma encontrou para reparar as imperfeições de sua constituição, à medida que seus bem intencionados reformadores topavam com maus costumes fortemente enraizados em seus cidadãos. Megaletor, "conhecendo claramente estes pontos e a necessidade de pensar o Parlamento de uma outra forma, convocou o exército para uma assembléia, onde manifestou suas impressões... com tal êxito, que o Parlamento foi dissolvido e ele mesmo... nomeado, por sufrágio universal do exército, Lord Arconte, o legislador único de Oceana" (107-8).

A sua obra, no entanto, não atingiu o seu objetivo implícito persuadir Cromwell, a quem é dedicada, a seguir os passos de Megaletor. Não só 
ela foi desdenhada pelo Lorde Protetor, como também o rumo que a Revolução de 1640 havia tomado tornara-se inexorável. Enfraquecido, Cromwell, em 1657, um ano após a publicação de Oceana, viu-se obrigado a aceitar a formação de um novo Parlamento e, em seguida, a promulgar uma nova Constituição, a Humble Petition and Advice, que retirava do exército todo o seu poder, transferindo ao Parlamento o controle financeiro do exército e o controle do protetorado; tornava o protetorado hereditário (surgiria, portanto, uma nova dinastia); e restabelecia a Câmara dos Lordes destinada a servir de fiel da balança entre os Comuns e o Lorde Protetor. Aos militares que eram contrários à nova Constituição, Cromwell disse: "Sei que muitos se sentem ofendidos com a Câmara dos Lordes. No entanto, devo adverti-los que enquanto não houver um sistema de balanço de poderes, não haverá liberdade" (d'Avack, 123-4). A sua tentativa de instaurar um governo estritamente pessoal falhara: o habilidoso Cromwell teve que se render ao momento. Sua única concessão aos militares foi a recusa do título de rei, que o Parlamento the outorgara. Antes desta Constituição chegar a funcionar satisfatoriamente, entretanto, Cromwell morreu (1658). Seu filho, que não estava à altura do pai, foi deposto num golpe palaciano. Em 1660, o Parlamento convocou Carlos II para assumir a coroa da Inglaterra (Hill, 101-7). Quando Carlos II entrou triunfalmente em Londres, em maio de 1660, os caminhos pelo qual passou estavam cobertos de flores, os sinos repicavam e das fontes da cidade corria vinho. Tão contente estava o povo pelo que ele considerava ser o restabelecimento do Antigo Regime, que um cronista da época chegou a observar maravilhado: "À margem dos acontecimentos, eu observava isto e agradecia a Deus. Tudo ocorria sem que fosse derramada um única gota de sangue e pela mesma multidão que antes se rebelara" (Weston, 443). Apesar deste fracasso inicial, a obra de Harrington continuará a influenciar sucessivos debates (que deveriam ser destacados nesta dissertação) ao longo do século XVIII, na Inglaterra. 


\section{AMÉRICA: MONTESQUIEU E A REVOLUÇÃO AMERICANA}

Por que, então, depois de tudo o que dissemos, o republicanismo que marcou as principais experiências políticas da Antigüidade e os principais debates políticos do início da modernidade, na Itália renascentista, na Inglaterra revolucionária e, como veremos, na América revolucionária - não se impôs? A resposta a esta questão encontramos no Espírito das Leis (1748) de Montesquieu - aquele que foi para os Federalistas "o oráculo sempre consultado e sempre citado" (№ 47). Do mesmo modo que os autores republicanos que tratamos anteriormente, Montesquieu pretende dar conta das experiências políticas do passado e do presente, classificando a diversidade das formas de governo através de tipos ideais. Estes são definidos a partir de dois critérios. A natureza de cada governo é determinada não só pelo número de governantes como também pela maneira como os governantes exercem o poder, enquanto que 0 princípio é o sentimento que anima os homens no interior de uma forma de governo, garantindo a sua estabilidade. Assim, a república é entendida como o governo de todo o povo (é importante notar, como faz Stourzh em seu artigo sobre Montesquieu, que o seu tipo ideal de república é democrático, pelo espaço que ocupa em sua confrontação com os outros dois tipos); a monarquia, o governo de um só através de leis fixas e preestabelecidas, portanto, um governo moderado; e o despotismo, o governo de um só sem leis, portanto, um governo ilimitado e incontrolado (Livro II, cap. I). No que diz respeito à sua estabilidade, Montesquieu quebra com a tradição, uma vez que estas formas de governo podem perdurar se a elas corresponder um princípio adequado: a virtude, na república; a honra, na monarquia; o temor, no despotismo (Livro III). Ao fazer tal distinção, Montesquieu não se prende exclusivamente à questão metodológica, referente à capacidade destes modelos de fazer com que possamos entender melhor uma realidade complexa; sua discussão é também normativa, ou seja, ele procura julgar qual é a melhor forma de governo. Neste sentido, o despotismo oriental, cujo exemplo mais significativo é o Império Turco, esteve sempre distante 
dos europeus (nosso autor não compartilha a visão de Hobbes de que o temor seria o único princípio a partir do qual um governo estável poderia ser construído) e as repúblicas da Grécia (curiosamente, Montesquieu inclui entre elas Atenas, onde, conforme a tradição, os seus cidadãos não primavam pela virtude cívica) e de Roma, tornam-se distantes do homem moderno. O modelo a ser imitado é a monarquia, cujo exemplo mais bem acabado é a inglesa. Antes, porém, de responder a questão normativa é interessante aprofundar as considerações de Montesquieu relativas ao seu modelo republicano e confrontá-las com as dos republicanos clássicos.

As três características centrais da república - a igualdade ética, política e econômica - estão presentes no tipo ideal de república de Montesquieu. No entanto, algumas distinções devem ser realçadas, antes de analisarmos as semelhanças. Ao afirmar que a virtude política é uma paixão (Livro III, cap. I), Montesquieu se distancia conscientemente de Aristóteles. Para este, a república também se funda numa virtude política (ou seja, numa disposição recíproca de preferir o bem dos outros ao bem próprio), embora a república deva contar previamente, para a sua constituição, com uma virtude não política (a liberalidade dos ricos), como vimos acima. Por outro lado, Aristóteles não entende que esta virtude possa ser fruto de uma paixão. Pelo contrário: ele a considera como uma disposição de impor limites às nossas paixões (o desprezo, a compaixão, o ódio, o amor, etc.). Para ele, cidadão é aquele que moldou o seu caráter a ponto de se ver livre das paixões, é aquele que alcançou por esforço próprio, pela autodisciplina, a sua natureza humana (zoon politikon) ao manter constantemente sob controle os seus impulsos animalescos. A distância entre os dois pensadores pode ser melhor medida se lembrarmos que por considerar o amor por si mesmo e o interesse particular sentimentos humanos naturais, Montesquieu define a virtude política como "un renoncement à soi-même" (Livro III, cap. V; Livro IV, cap. V). Neste sentido, Montesquieu se afasta de Aristóteles, para se aproximar do "judicioso" Políbio, para quem (assim como Cícero e Leonardo Bruni) a virtude política é reconsiderada como uma paixão: o amor pela pátria acima do amor 
próprio e o interesse público acima do interesse particular. $O$ que foi para 0 historiador grego uma das causas da estabilidade política de Esparta e Roma (a outra foi a sua constituição mista), é também para o filósofo francês o princípio das repúblicas antigas: "o amor pela pátria... aquele amor que demanda uma preferência contínua do interesse público sobre o interesse próprio" (Livro IV, cap. V). A importância desta constatação se deve ao fato que, sendo a virtude uma paixão, "até mesmo o último homem pode compartilhar deste sentimento" (Livro V, cap. II). Ou melhor, sendo a república uma forma de governo popular cujo motor é a virtude de todos que a compõem, não podemos esperar que ela provenha do autocontrole de cada um de seus cidadãos, mas que seja incutida em todos. Isto só é possível, conforme o pensador francês, se considerarmos algo que foi da maior importância nas Repúblicas Espartana e Romana, mas que, em geral, está ausente nos republicanos clássicos: a paideia. Neste ponto, Montesquieu se aproxima de Leonardo Bruni: a solução da contradição subjacente no republicanismo aristotélico - a conciliação entre o governo de todos e uma virtude comum a todos, dificilmente alcançada se dependermos unicamente do autocontrole dos cidadãos -, que, em Políbio, é resolvida, exclusivamente, através dos preceitos e espetáculos cívicos e da religião cívica, é, em Montesquieu, resolvida, de maneira privilegiada, pela educação. A ela cabe moldar o caráter de uma nação, a ela cabe, especificamente, o despertar de uma paixão comum, o amor da pátria, necessário ao funcionamento desta forma de governo (Livro IV, cap. V). (Portanto, há um exagero na oposição de Montesquieu à doutrina clássica da virtude, como pretende Stourzh (1965, 249-50), ao considerá-la como sendo unicamente aristotélica, cristã e tomista).

Ainda com relação à igualdade ética, a acentuada ênfase no papel da educação cívica na república, em Montesquieu, não negligencia o papel dos preceitos (sobre a religião e os espetáculos cívicos de Roma, entretanto, não há nenhuma menção). Para ele, uma república "deve banir o dinheiro", como fez Licurgo (Livro IV, cap. VII). Apesar da economia desta afirmação, podemos aproximar Montesquieu tanto das considerações de Aristóteles, acerca das 
atividades lucrativas, isto é, da necessidade de dar prioridade à atividade agrária, quanto de Políbio, acerca dos preceitos cívicos dos espartanos, em particular, no tocante ao controle da circulação do dinheiro e ao escambo entre as mercadorias. Mas isto não é tudo o que Montesquieu tem a dizer sobre as características centrais da república. Não só a igualdade ética e a igualdade política são necessárias à república, mas também a igualdade material. Segundo Montesquieu, o amor à pátria é também amor à igualdade e à frugalidade. Numa república "cada um deve ter a mesma felicidade e as mesmas vantagens, deve saborear os mesmos prazeres e alimentar as mesmas esperanças"; nela, o désir d'avoir deve ser limitado ao que é estritamente necessário para o sustento da família, reservando-se o supérfluo para a pátria (Livro V, cap. III). Entretanto, os homens só podem exercer esta disposição ou ser educados a ela se nascerem numa comunidade onde haja igualdade e frugalidade (Livro V, cap. IV). Este é o mérito, por exemplo, de Licurgo: ter não só distribuído eqüitativamente as terras, como também instituído uma lei fundamental que manteve tal distribuição regrando, para tanto, os dotes das mulheres, as doações, as sucessões, os testamentos, etc. (Livro V, cap. V). Mais do que Aristóteles, uma aproximação com o fundador e a lei agrária de Harrington é inevitável. Vale relembrar que a igualdade de posses, que esta lei agrária propicia, visa a autonomia econômica e o ócio, sem os quais, segundo a visão dos republicanos que estudamos, não haveria virtude nem participação direta de todos no governo.

Finalmente, Montesquieu cita duas outras condições, que reforçariam os três pilares da igualdade, cerne do ideal republicano. A primeira condição é não ser expansionista. "O espírito da república é a paz" (Livro IX, cap. II), e não a expansão do seu território - a primeira foi motivo da durabilidade de Esparta; a segunda, o motivo principal da queda da República Romana, conforme as suas Considerações sobre as Causas da Grandeza dos Romanos e de sua Decadência. A segunda condição se dá quando a extensão territorial da república e o número dos cidadãos for reduzido - uma condição que depende mais dos caprichos da fortuna que da prudência do legislador. Novamente, nos 
aproximamos das ponderações de Aristóteles, de que somente numa pequena cidade pode nascer um relacionamento face a face, que permite não só a confiança mútua como também o controle mútuo sem os quais um governo popular não sobreviveria. "Numa república grande, o bem comum é sacrificado por mil considerações... numa pequena, ele é melhor sentido, está mais perto de cada cidadão" - e, mais uma vez, Licurgo é citado como exemplo (Livro VIII, cap. XVI). Daí, a necessidade de se criar uma federação de repúblicas - uma novidade com relação à tradição -, porque "se uma república é pequena, ela é destruída por uma força estrangeira; se ela é grande, ela é destruída por um vício interior" (Livro, IX, cap. I). Por outro lado, estas duas últimas considerações o afastam de Harrington, para quem o expansionismo e as dimensões de Roma e da Inglaterra são positivas para a república.

Este tipo ideal de república, descrito nos dez primeiros Livros de Montesquieu - e que se aproxima muito de Esparta, cuja única e grande mácula, desconsiderada pelo pensador francês, foi não contar com uma superestrutura que propiciasse a igualdade política -, entretanto, não pode mais ser realizado; pois, como ele mesmo constata, nestas repúblicas da Antigüidade "fazia-se coisas que não mais vemos hoje e que surpreendem nossas pequenas almas" (Livro IV, cap. IV). Hoje, considera Montesquieu, estas condições prévias à república não são encontradas em parte alguma: as nações, de extensão e população imensas, tomaram o lugar das cidades; com elas instituiu-se uma sociedade pluralista e conflituosa; e a atividade determinante que a mantém unida é o comércio. Assim como Harrington pensa que a fundação da república deve contar com a fortuna para alcançar um fundamento que lhe sirva de base, também para Montesquieu, não é tarefa do legislador recriar as condições prévias para uma comunidade homogênea, isto é, para uma comunidade onde todos são movidos pelo mesmo interesse (o bem comum), pela mesma paixão (o amor pela pátria). Ao contrário de todos os republicanos clássicos, entretanto, Montesquieu não só acredita ser possível uma forma de governo estável fundada nas "paixões particulares", como também afirma ser a melhor forma de governo, nos dias de hoje, exatamente 
aquela que garante a livre fruição destas paixões - pois, esta é a conclusão deste seu capítulo, tão longe estamos dos valores prezados pelos antigos que hoje eles nos surpreendem. Tal convicção é fruto de sua interpretação da monarquia inglesa de sua época, onde "o povo é livre", quer dizer, onde "todas as paixões sendo livres, o ódio, a inveja, o ciúme, o ardor de se enriquecer e se distinguir, aparecem em toda a sua extensão" (Livro XIX, cap. XXVII). A igualdade (ética, sócio-econômica e política), portanto, deixa de ser, a partir de então, a característica central da forma de governo ideal.

No famoso capítulo VI do Livro XI, intitulado Da Constituição da Inglaterra, mais que uma descrição da realidade, encontramos a prescrição de uma monarquia ideal. À medida que esta se aproxima da monarquia inglesa, maior é a sua distância para com as outras monarquias, visto que estas não têm como objetivo a liberdade mas a honra (Livro XI, cap. VII). A sua preocupação central é demonstrar como, sob a condição moderna do primado absoluto do interesse próprio, do desejo de enriquecimento e de influência pessoais, a sua constituição possibilita o máximo de liberdade; ou seja, argumentar como numa sociedade, na qual as paixões particulares são liberadas e comuns a todos, na qual, portanto, a luta por mais riqueza e por mais poder predominam, a separação e o controle recíproco dos poderes são as únicas garantias da liberdade individual (Stourzh, 1965, 252). Para Montesquieu, a questão política moderna não é mais como fazer com que os homens livres sejam também iguais, mas sim como eles podem promover os seus interesses particulares sem escravizarem uns aos outros. Para ele, a questão política crucial não é mais a manutenção da igualdade (papel atribuído à educação cívica, à lei agrária e ao arranjo institucional), mas, especificamente, a limitação e o controle do poder, para que os indivíduos possam ser livres da interferência do governo em seus afazeres: "para que não se possa abusar do poder, é necessário, pela disposição das coisas, que o poder detenha o poder" (Livro XI, cap. IV).

Assim, resumindo este famoso capítulo, para que um governo propicie a "liberdade política", "aquela tranqüilidade de espírito que provém da 
opinião que cada um tem de sua segurança", a ponto de "um cidadão não precisar mais temer um outro", ele precisa ser ordenado da seguinte maneira. Primeiramente, deve haver uma separação dos poderes, quer dizer uma separação das funções do governo entre: o Legislativo, que faz as leis e corrige ou anula as existentes; o Executivo, que faz a paz e a guerra, recebe ou envia as embaixadas, estabelece a segurança e previne as invasões; e o Judiciário, que pune os crimes e julga as diferenças dos particulares. Quando a mesma pessoa ou o mesmo corpo de magistrados reúne o Legislativo e o Executivo não há liberdade; do mesmo modo, quando o Judiciário não está separado do Legislativo e do Executivo não há liberdade. Em segundo lugar, deve haver uma distribuição dos poderes entre os diferentes grupos que formam a sociedade - no caso, os três estados. Quando o rei ou os nobres ou o povo exercem os três poderes não há liberdade - como no Império Turco e na República Veneziana, onde os nobres exercem os três poderes. Assim, na separação (funcional e social) dos poderes, delineada por Montesquieu, o Executivo deve estar nas mãos do monarca (porque esta parte do governo deve contar com ações rápidas) e o Legislativo deve ser confiado a um corpo de nobres (hereditário) e a um corpo dos representantes eleitos pelo povo, reunidos separadamente e deliberando separadamente (a Câmara Alta e a Câmara Baixa). O Legislativo não deve se reunir por ele mesmo, e sim ser convocado pelo Executivo, que dirá quando e por quanto tempo. Finalmente, deve haver um controle recíproco entre estas duas instâncias de poder (o Judiciário é neutro). O Executivo deve ser dotado da faculdade de impedir (o direito de tornar nula a resolução da outra parte) o Legislativo (para que este não seja tirânico), mas o Legislativo não deve ter o poder de deter o Executivo (pois este, por sua natureza, já tem seus limites), e sim o poder de examinar de que maneira as leis são executadas por ele. $O$ Legislativo deve ser composto de duas partes, para que cada uma seja dotada da faculdade de impedir a outra, que, por sua vez, devem poder sofrer a faculdade de impedir do Executivo. Quando não há tal controle a liberdade não existe. 
Visto sob o ângulo social, o resultado desta engenharia constitucional (a "separação dos poderes") não é o repouso, mas obrigar que as diversas partes andem em conformidade umas com as outras - o seu objetivo é produzir um compromisso entre as partes conflitantes. Esta convicção de Montesquieu é proveniente, evidentemente, de seu longo convívio com o mito inglês, quando viveu na Inglaterra entre 1729-32. Do mesmo modo que os ingleses da última metade do século anterior acreditavam, também para ele, a origem da monarquia inglesa é medieval, devendo às "nações germânicas" os rudimentos institucionais a partir dos quais se solidificou o seu governo atual. Também para ele, trata-se de um governo misto: no início o seu "governo gótico", compreendia uma "mistura de aristocracia e monarquia"; e, mais tarde, a esta mistura se acrescentou um elemento novo, nascido do impulso que as relações econômicas haviam tomado com o mercantilismo, a partir do século XVI - a burguesia passa a assumir o elemento democrático. Também para ele, esta é a melhor forma de governo que os homens poderiam imaginar: todos fruem a sua liberdade ao mesmo tempo em que todos estão livres do poder abusivo de qualquer uma das partes (Livro XI, cap. VIII). Influenciadas, como dissemos, mais pelo ambiente ideológico do que pela experiência política inglesa pósrevolucionária, estas considerações de Montesquieu sobre o governo inglês serão decisivas (como podemos depreender do estudo de Spurlin) no confronto ideológico travado nas colônias americanas entre a sua independência (1776) e a Convenção Federal de 1787, ratificando a Constituição americana, que entrará em vigor no ano seguinte. Para os seus defensores, estarão sempre presentes as recomendações do pensador francês de que onde o território é extenso e a população imensa, onde a sociedade é pluralista e conflituosa e a sua atividade central é o comércio, a liberdade, entendida como a livre fruição das paixões e interesses particulares, necessita de um arranjo institucional próprio que a garanta. Não podemos esquecer também que tanto quanto Montesquieu, os seus seguidores na América ainda estavam sob a influência da propaganda ideológica constitucionalista, nascida durante a Revolução Inglesa, segundo a qual, nem a 
monarquia, nem a aristocracia, nem o povo pode separadamente assumir 0 governo sem que este se torne arbitrário.

Um breve resumo dos acontecimentos políticos que antecederam a Convenção nos ajudará a entender melhor as razões que permearam este confronto. Com o Tratado de Paris (1763), o Império Britânico atingira o seu apogeu. A França, o seu maior inimigo, perdera praticamente todos os seus territórios na América do Norte, ao mesmo tempo em que a Inglaterra se firmava como a nação mais poderosa da Europa. Uma vez alçada a esta posição privilegiada, o Império inicia uma busca desesperada de recursos não só para recuperar as despesas de um longo período de guerra, como também para colonizar e administrar satisfatoriamente tanto os seus antigos quanto os novos e extensos territórios recém-incorporados. Sempre encarando as colônias como fonte de matérias-primas e mercado consumidor de seus produtos industrializados, o Parlamento inglês agora se sente em condições de redobrar os esforços para legislar os territórios da coroa britânica no intuito de contar com o dinheiro de que necessitava. Este plano, no entanto, fracassará por dois motivos. Primeiramente, o Parlamento parecia não perceber que as treze colônias inglesas plantadas na América já não eram simples apêndices da Inglaterra. Além do mais, os ingleses foram extremamente inábeis: eles faziam dos americanos cidadãos britânicos de segunda classe, ignorando que, de direito, eles eram tão ingleses quanto os londrinos. Ser cidadão inglês não significava apenas ser súdito do rei da Inglaterra; mais que isso, comportava uma série de direitos, tais como o de ser julgado segundo as normas processuais e as garantias do direito britânico, de tratar dos negócios da comunidade através de representantes próprios, eleitos para o Parlamento, e assim por diante. Portanto, os americanos viam em seus tribunais e assembléias, nas instituições e direitos reconhecidos na carta colonial, a própria essência da cidadania inglesa, que estavam dispostos a defender.

Para sanar a crise financeira que se instalara, o Parlamento, em 1764, vota a Lei do Açúcar, impondo altas taxas sobre os lucros dos comerciantes de rum das colônias. No ano seguinte, é aprovada a Lei do Selo, estabelecendo 
tributos sobre os documentos públicos. Estas duas leis são o estopim da revolta das treze colônias. Nas assembléias locais, após inflamados discursos, votam-se resoluções afirmando que as treze colônias não aceitarão estes impostos, já que elas não têm representantes no Parlamento que as decretou. $\mathrm{Na}$ impossibilidade de ver executada a Lei do Selo, o Parlamento suspende a sua aplicação em 1776; mas volta a carga em 1767, editando os Atos Townshend, pelos quais seriam aplicadas taxas alfandegárias sobre a importação de chá, chumbo, verniz, entre outros produtos. Nas colônias a reação é imediata. Associações patriotas promovem manifestações públicas; queimam-se efígies dos personagens favoráveis à Inglaterra; decide-se boicotar o comércio inglês, deixando de comprar os produtos tradicionalmente exportados pela Inglaterra. O protesto geral se acentua quando o Parlamento inglês determina o fechamento da Assembléia de Nova York, que se recusa a votar as verbas necessárias à manutenção das tropas inglesas na colônia - tratava-se de um ato sem precedentes, pois, até então, apenas os governadores, como representantes do rei, podiam intervir nas Assembléias. Na Virgínia, a Assembléia vota uma mensagem ao rei, um memorial à Câmara dos Lordes e uma queixa à Câmara dos Comuns. Em 1770, o Parlamento cede parcialmente aos protestos, temendo que algo de pior aconteça. Revoga os impostos aduaneiros, à exceção do que incide sobre o chá (Tea Act). Com isso, consegue aplacar por algum tempo o movimento antibritânico. Mas os primeiros tiros da guerra anglo-americana tinham sido disparados, com a morte de três cidadãos de Boston. Em dezembro de 1773, a crise explode novamente. O tea party, um grupo de cidadãos de Boston disfarçados de índio, assaltam um navio britânico e lançam ao mar trezentas caixas de chá. Mais do que a taxa incidente, o que motiva este atentado é o fato do monopólio da importação de chá estar nas mãos da Companhia das Índias, empresa britânica que competia deslealmente com os americanos que viviam da importação do produto. A reação dos ingleses é imediata: suas tropas bloqueiam o porto de Boston, que só será reaberto quando for pago o chá lançado ao mar. Por decisão do Parlamento, o governador da Virgínia fecha a Assembléia, foco principal da insurreição. 
Os colonos respondem convocando uma reunião com representantes de todas as colônias: é o Primeiro Congresso Continental, realizado em Filadélfia, em setembro de 1774, com a presença de 55 delegados de todas as colônias, à exceção da Geórgia. Há divergências políticas, mas todos concordam num ponto básico: as colônias devem obedecer ao rei nas guerras exteriores e nos tratados de paz, mas no resto são livres para se autogovernarem, tendo as suas Assembléias, dentro dos respectivos territórios, a mesma autoridade que o Parlamento na Inglaterra. O Primeiro Congresso Continental organiza um boicote eficaz dos produtos britânicos, envia ao rei Jorge III uma petição e ao povo inglês uma Declaração dos Direitos e das Queixas das Colônias. No entanto, a metrópole recusa-se a negociar. Em 1775, realiza-se o Segundo Congresso Continental, na Filadélfia. Lá, constatando-se que há um clima de rebelião aberta em várias regiões das treze colônias, decide-se pela formação de milícias e pela provisão de recursos. Discute-se muito, mas a conclusão é uma só: esgotaram-se as possibilidades de negociação; agora, resta partir para a luta contra os ingleses. À medida que a guerra avança, o governo inglês nas colônias vai desmoronando. Os governadores, já sem autoridade, ou fogem para a Inglaterra ou são feitos prisioneiros. No lugar do antigo sistema, um novo começa a se formar, a partir das seguidas sessões do Congresso de Filadélfia - são discutidas resoluções sobre crédito, comércio, sistema postal, formas de administração, entre outras. Nomeia-se uma comissão, incumbida de redigir uma declaração de independência. Após três dias de trabalho, durante os quais se destaca a participação de Thomas Jefferson, o Segundo Congresso Continental aprova solenemente a Declaração da Independência, em 4 de julho de 1776. Apesar do debate que se acende sobre a forma de governo a ser adotada, o centro das atenções do Congresso está em garantir militarmente a independência recém-declarada. À frente de seu improvisado exército está George Washington (primeiro presidente da futura República Americana), ajudado por alguns voluntários europeus, que atenderam ao apelo universalista dos revolucionários americanos, como o francês La Fayette, o prussiano Steuben e o 
polonês Koscinsko. A vitória, entretanto, só começa a pender para o lado americano, quando, graças ao excelente trabalho diplomático de Benjamin Franklin em Paris, em 1780, desembarca na América um enorme e disciplinado exército francês, comandado pelo Conde de Rochambeau. Finalmente, em outubro de 1781, os ingleses cessam o fogo e pedem conversações para a paz. Em 3 de setembro de 1783 é assinado o armistício, em Paris; e, em novembro, as tropas inglesas deixam definitivamente o continente americano.

Nos Artigos da Confederação, redigidos em 1777 e adotados em 1781, o Congresso Continental estabelecera uma liga de Estados independentes, formada por cada uma das treze colônias. A partir de então, intensifica-se um movimento contra a Confederação, um movimento pela união dos Estados. $\mathrm{O}$ debate que se segue só se concluirá com a Convenção de setembro de 1787 . Foi basicamente em torno de Montesquieu e do mito inglês que se formaram as duas principais correntes políticas que dominaram o debate americano nestes anos: os defensores da Federação, cujos expoentes maiores foram James Madison, Alexander Hamilton, Thomas Paine, Benjamin Franklin e John Adams, e os seus oponentes, capitaneados por nomes de menor expressão, como Samuel Adams, Patrick Henry, Richard Henry Lee, Richard Yates e Dewitt Clinton. Preocupados com a formação de um governo popular que "combine estabilidade e liberdade", os primeiros estavam cientes de que "as democracias da Grécia e da Itália... estiveram sujeitas a uma contínua sucessão de revoluções, que as mantinham num estado de perpétua incerteza entre os estádios extremos da tirania e da anarquia" (Os Federalistas № 63). Por outro lado, as experiências constitucionais antigas, que, segundo a sua concepção, proporcionaram um governo estável mediante mecanismos de controle e limitação do poder, contaram com uma monarquia e uma aristocracia hereditárias como contrapeso ao governo arbitrário do povo, como em Esparta, Roma e, principalmente, na Inglaterra. (Segundo a sua visão, Esparta e Roma foram experiências constitucionais, e não republicanas, o que demonstra o impacto do mito inglês entre eles, ao passo que Veneza - "onde alguns nobres hereditários exercitam sobre a massa do povo o 
mais absoluto poder" (Os Federalistas, $\mathrm{N}^{\circ}$ 39) - passa a ser concebida, a exemplo de Montesquieu, de forma mais realista). A grande novidade é que os americanos teriam descoberto, pela primeira vez, como resgatar o objetivo central das democracias ateniense e italianas (o modo de vida livre), evitando as suas conseqüências funestas (o interminável e sangrento conflito das facções). Paine resumiu de maneira muito feliz, alguns anos mais tarde, nos Direitos Humanos (1791), a intenção desta descoberta: "O que Atenas foi em miniatura, América será em magnitude" (66).

Devemos a Madison a exposição clássica desta questão e a sua solução, em particular em Os Federalistas (1787) $\mathrm{N}^{\circ} 10$ e $\mathrm{N}^{\circ} 51$. A facção entendida como "um grupo majoritário ou minoritário de cidadãos unidos e dirigidos pelo impulso de uma paixão ou interesse contrário aos direitos dos outros cidadãos ou ao interesse constante e geral da sociedade" ( $\left.\mathrm{N}^{\circ} 10\right)$ - tem como causa principal a desigual distribuição das propriedades. A sua eliminação mediante a homogeneização das paixões e interesses - a solução do republicanismo clássico -, no entanto, foi descartada, visto que se a facção, e, portanto, a desigualdade das posses, existe é porque "a sua origem se deve à desigualdade das faculdades humanas", e "a proteção destas faculdades é o primeiro fim do governo" ( $\left.\mathrm{N}^{\circ} 10\right)$. No intuito de proteger o livre curso das facções, e, conseqüentemente, do acúmulo ilimitado de riquezas, é proposto dois arranjos institucionais em dois níveis. No primeiro, a União (ao estender o número de cidadãos, abrangendo um território extenso) aliada à representação (ao tirar o governo das mãos do povo, transferindo-o para um pequeno grupo de governantes eleitos, desprovidos de qualquer mandato imperativo) evitariam a formação, como nas democracias antigas, de um grupo majoritário que impediria a livre fruição dos interesses de outros grupos. Entretanto, os defensores da Constituição tinham em mente o que acorreu quando os representantes do povo, assentados na Câmara dos Comuns, assumiram sozinhos o Parlamento inglês, durante a Revolução de 1640, acirrando o descontentamento público devido ao seu governo arbitrário. Pensando em substituir o papel moderador que a 
monarquia e a aristocracia hereditárias exerciam - dentro da perspectiva do mito inglês, assumido por Montesquieu -, Madison idealiza um segundo arranjo institucional. Para evitar que os governantes eleitos pelo povo exerçam um poder abusivo, é proposto no $N^{\circ} 51$ a separação das funções de governo e o controle mútuo entre o Executivo (que representa a União), o Senado (representante dos Estados da União) e a Câmara dos Representantes (assento dos representantes do povo). Complementa estes dois arranjos institucionais - esta é a principal contribuição de Hamilton ( $N^{\circ} 78$ ), também inspirada em Montesquieu - o judicial review, ou seja, um poder neutro, o Poder Judiciário, cuja função seria a de garantir que nenhuma nova lei fira a Constituição.

Profundamente incomodados com os rumos que estes queriam dar à nação, insurge-se um pequeno grupo de autores, que por não terem legado, como os seus oponentes, nenhuma obra de destaque, ficaram conhecidos simplesmente como Anti-Federalistas. Mesmo sendo um pequeno grupo de autores não tão bem preparados para o debate que se seguiu nesta década, a contraposição de idéias é importante para avaliarmos melhor quanto os defensores da Federação se distanciaram do republicanismo clássico. O seu núcleo de idéias, apesar das contradições e dificuldades de interpretação que elas apresentam, nascem, conforme depreendemos do importante trabalho de Gordon Wood, de uma reação não só à unificação, mas principalmente ao peso que a sociedade capitalista assumia no debate político. Estes foram os pontos centrais de divergência para com os seus opositores - outros pontos de divergência, como os relativos ao sistema de checks-and-balances, à separação dos poderes e ao Bill of Rights, são de pouca importância para o nosso intento. Essencial, neste debate, foi a retomada de tópicos do republicanismo clássico (neste caso, não podemos falar em uma doutrina) para contestar os seus oponentes. A intenção que circundava os escritos dos Anti-Federalistas "era fundamentalmente anticapitalista; foi a última tentativa de dar conta de uma sociedade individualista emergente, que ameaçava destruir de vez e para sempre a solidariedade e a benevolência, que os homens civilizados sempre 
consideraram ser um comportamento humano ideal" (Wood, 1969, 418-9). Ainda nestes textos, reencontramos a concepção da esfera política como "uma unidade orgânica coesa formada por um único interesse homogêneo" (Wood, 1969, 499); a crença na virtude cívica, como princípio homogeneizador, e, portanto, estabilizador, de um governo popular, se opondo ao interesse próprio, entendido como elemento desagregador. Reencontramos, ainda, a defesa da restrição da extensão do país, do número de habitantes e, não menos importante, das diferenças sociais e de posse. E, por último, reaparece a exaltação da participação direta e a desconfiança para com a representação. Mesmo que de maneira esparsa, ressurge a crença na igualdade ética, política e econômica como alternativa à proposta dos opositores, como apontamos em outros republicanos clássicos. $O$ debate entre Anti-Federalistas e unionistas, embora de modo difuso, foi marcado pelas dicotomias que os autores do passado (Harrington e Montesquieu, em particular) apontaram ao compararem o constitucionalismo com o republicanismo: o indivíduo contra a comunidade, a liberdade contra o dever, o interesse contra a virtude, a pluralidade contra a homogeneidade, a representação contra a participação direta. Entretanto, este impulso republicano estava fadado a retroceder: "esta visão estava tão distante da realidade da sociedade americana, tão contrária às experiências americanas deste século, que podemos considerá-la uma das mais utópicas da história americana" (Wood, 1969, 54). (Seriam extremamente úteis, para uma melhor compreensão deste debate, as análises detalhadas de Boorstin, Bailyn, Wood e Stourzh sobre a formação do pensamento político americano).

Até mesmo alguns unionistas célebres compartilhavam, em parte, este impulso. Benjamin Franklin, liberal convicto e defensor entusiasta da nova Constituição, desaprovava a vida luxuriosa, advinda da riqueza, e acreditava que os americanos deveriam preservar, através da redistribuição (não necessariamente eqüitativa) das posses, o que ele chama happy mediocrity, uma vida simples, entre os extremos da riqueza e da pobreza (Young, 633). Thomas Jefferson, outro grande defensor da União e da representação política, também 
deixou transparecer, ao menos em algumas de suas cartas, um certo ardor republicano. Além de, em certos momentos, desconfiar da crescente industrialização, preferindo, em seu lugar, o retorno à atividade agrária, Jefferson propõe a introdução daquilo que ele considera "os dois baluartes" do governo republicano: "a educação pública e a subdivisão dos condados em distritos" (Escritos Políticos, 43). Que esta educação pública apresenta rudimentos de uma educação cívica, parece ser comprovada pela ênfase daquela para a manutenção da forma de governo republicano: "Educai e esclarecei toda a massa do povo. Capacitai-o a ver que é do interesse dele preservar a paz e a ordem, e ele as preservará" (21). Ao mesmo tempo, ele expressa, em outras cartas, uma certa simpatia pela igualdade política. Ao dividir a União em Estados, os Estados em distritos e os distritos em condados, "não haverá um homem sequer que não será membro de algum de seus conselhos, grandes ou pequenos" (45). Não devemos esquecer que esta mesma grande personalidade política, em outras ocasiões, afirmou que "uma república pura... na qual todo membro de espírito maduro e são tem igual direito de participar pessoalmente na direção dos negócios da sociedade" é "impraticável além dos limites de um acampamento ou de uma pequena aldeia" (10). Ou ainda: "Os tempos modernos têm agora esta vantagem evidente, a de ter descoberto o único processo pelo qual esses direitos [os direitos do homem] podem ser assegurados, a saber: o governo pelo povo, agindo não em pessoa, mas por meio de representantes eleitos pelo próprio povo" (14). Esta confusão de elementos constitucionais liberais com elementos republicanos pré-modernos, na formulação de uma mesma forma de governo, não se repete em John Adams (um autor que, pela sua importância para o tema, mereceria um destaque maior nesta dissertação). Em seu caso, nota-se claramente uma transformação na sua maneira de pensar a república, entre os anos setenta e noventa do século XVIII. "A felicidade da sociedade é o fim do governo", afirma repetidamente Adams em A Defence of the Constitutions of the United States, e, continua, "ela consiste no exercício da virtude", à medida que "as paixões particulares são canalizadas para o bem comum". Pouco a pouco, no entanto, 
esta visão inicial, que faz da virtude o princípio da república, é substituída por outra mais pessimista. De um plano secundário, na Defence, a concepção de governo misto - onde seus três elementos constitucionais (a monarquia, a aristocracia e a democracia) se associam aos dois grupos em conflito que formam a sociedade (os ricos e os pobres, os poucos e os muitos), propiciando a paz e a tranqüilidade social - passa a ser, em seus escritos posteriores, a característica central de sua república (Nolte, 217-25). (A tentativa de Arendt, em Sobre a Revolução, de enquadrar Adams, juntamente com Jefferson, na linhagem do republicanismo clássico, pelas considerações que fizemos, só em parte pode ser aceita). Resignado, ele, como tantos outros envolvidos neste debate, rende-se às considerações de Montesquieu sobre a inconsistência de se reabilitar a república dos antigos; resignado, ele concede que o homo oeconomicus assuma o lugar do homo politicus.

Concluindo. Em três momentos diferentes, na Itália, na Inglaterra e na América, inicia-se um debate, no qual a retomada do ideal republicano é apontado como uma alternativa à crise política advinda do desmoronamento da sociedade feudal. Porém, por maior que fosse o impulso na direção deste ideal, ele foi suplantado por uma força antagônica emergente. Ao mesmo tempo em que o republicanismo assume nestes momentos um importante papel no debate político e os seus ideólogos passam a ser referência para as gerações futuras, a burguesia ascende politicamente e expande os seus valores para a sociedade. A partir de então, a igualdade ética (obtida por meio da educação cívica, dos preceitos e espetáculos cívicos e da religião cívica), a igualdade política (propiciada pelo rodízio dos cargos públicos), a igualdade sócio-econômica e militar (alcançada pela lei agrária), que caracterizavam o ideal republicano clássico - o bios politikos, a vita activa, o politice vivunt -, perdem o sentido. $\mathrm{Na}$ discussão sobre a melhor forma de governo, o ideal da igualdade é substituído pelo da liberdade. Com esta afirmação queremos dizer, em primeiro lugar, que para o republicanismo antigo não bastava que os homens fossem livres - motivo principal da confusão dos autores que tratamos na Introdução; pois, como vimos, 
a república só existe quando os livres e nativos são também iguais. (Neste ponto nos distanciamos das considerações de Cícero Araújo e Janine Ribeiro, para os quais a república, pelas exigências que faz aos seus membros, restringe a cidadania a poucos; e nos aproximamos de Sérgio Cardoso, para quem a república não apenas supõe a integração de todos, como também a promove). Queremos dizer também que, apesar de se distinguir do constitucionalismo antigo, ao assumir um novo ideal de igualdade - entendido como uma concessão a todos os homens do direito à cidadania, no intuito de impedir tanto a escravidão e a servidão, quanto qualquer outra forma de opressão -, a marca central do republicanismo moderno continua sendo a garantia do modo de vida livre - agora, para todos os homens. Para aqueles que tomaram o modo de vida livre como $o$ eixo em torno do qual a forma de governo é constituída, o modo de vida republicano representa uma grande restrição à liberdade de fazer o que se quer, pois é exigido uma homogeneização do comportamento, da atividade econômica e da propriedade. Não há, portanto, como traçar qualquer linha de parentesco entre o republicanismo antigo e o constitucionalismo antigo e moderno, ou mesmo entre as experiências republicanas e constitucionais. São opções de vida, irreconciliáveis entre si. 


\section{BIBLIOGRAFIA}

AALDERS, G.J.D.: "Die Mischverfassung und ihre historische Dokumentation in den Politica des Aristóteles". Em: La "Politique" d’Aristote. Genebra, 1965.

---- "Die Theorie der gemischten Verfassung im Altertum". Amsterdam, 1968.

ADAIR, D.: "The Tenth Federalist Revisited". Em: William \& Mary Quaterly, vol. III, 8, 1951.

---- "That Politics May Be Reduced to a Science": David Hume, James Madison, and the Tenth Federalist'. Em: Huntington Library Quarterly, 20, 1957.

--- "The Federalist Papers. A review article". Em: William \& Mary Quaterly, III, 22, 1965.

ADAMS, W. P.: "Republikanische Verfassung und burgerliche Freiheit". Darmstadt, 1973.

ALBERTINI, R. von: "Das florentinische Staatsbewusstsein im Übergang von der Republik zum Prinzipat”. Bern, 1955.

ARAUJO, C.: "República e democracia”. Em: Lua Nova, 51, 2000.

ARENDT, H.: "Sobre a revolução". Lisboa, 1971.

---- "Crises da república". São Paulo, 1973.

---- "Entre o passado e o futuro". São Paulo, 1979.

---- "Vita Activa". München/Zürich, 1981.

ARISTÓTELES: “Éthique a nicomaque”. Tradução e comentários de J. Tricot. Paris, 1979

---- "La politique". Tradução e comentários de J. Tricot. Paris, 1989.

---- "Der Staat der Athener". Stuttgart, 1987.

AUBENQUE, P.: "La prudence chez Aristoteles". Paris, 1986. 
BAILYN, B.: "The Ideological Origins of the American Revolution". London, 1967.

BARKER, E.: "The political thought of Plato and Aristotle". New York, 1906.

BARON, H.: "In search of florentine civic humanism". Princeton, 1988.

---- "Crisis of the Early Italian Renaissance". Princeton, New Jersey, 1993.

---- "Machiavelli: the Republican Citizen and the Author of 'The Prince'". Em: English Historical Review, 76, 1961.

BATTAGLIA, F.: "La Dottrina dello Stato Misto nei Politici Fiorentini del

Rinascimento". Em: Rivista Internazionale di Filosofia del Diritto, 7, 1927.

BIEN, G.: "Revolution, Bürgerbegriff und Freiheit". Em: Philosophisches Jahrbuch, 79, 1972.

---- $\quad$ "Bemerkungen zum Aristotelischen Politikbegriff und zu den Grundsätzen der Aristotelischen Staatsphilosophie". Introdução à "Politik". Hamburg, 1981.

---- "Himmelsbetrachter und Glücksforscher". Em: Archiv für Begriffsgeschichte, 26, 1982.

---- (a) "Vernunft und Ethos". Introdução à "Nikomachischen Ethik". Hamburg, 1985.

(b) "Die Grundlegung der politischen Philosophie bei Aristoteles".

Freiburg/München, 1985.

BIGNOTTO, N.: "Maquiavel republicano". São Paulo, 1991

---- "Apresentação" e "Humanismo cívico hoje". Em: Newton Bignotto, Pensar a República. Belo Horizonte, 2000.

BLEICKEN, J.: "Die athenische Demokratie". Paderborn/München/Wien/Zürich, 1988. 1989.

---- "Die Verfassung der römischen Republik". München/Wien/Zürich,

BOBBIO, N.: "A teoria das formas de governo". Brasília, 1985.

"Governo misto". Em: N. Bobbio, N. Matteucci e G. Pasquino, Dicionário de Política. São Paulo, 1986. 
BOORSTIN, D.J.: "The Genius of American Politics". Chicago, London, 1953.

--- "The Americans: The Colonial Experience". New York, 1958.

BOSE, H. von: "Republik und Mischverfassung - zur Staatsformenlehre der Federalist Paper". Frankfurt a.M., Bern, New York, Paris, 1989.

BRANDT, R.: "Untersuchungen zur politischen Philosophie des Aristoteles". Em: Hermes, 102, 1974.

BRAUN, E.: "Die Summierungstheorie des Aristoteles". Em: Jahresheft des österreichischen archäologischen Institutes in Wien, 44, 1959.

---- "Die Theorie der Mischverfassung bei Aristoteles". Em: Wiener Studien. Zeitschrift für klassische Philologie und Patristik, 1, 1967.

BRUNNER, O: "Das 'Ganze Haus' und die alteuropäische 'Ökonomik'”. Em: O.Brunner, Neue Wege der Sozialgeschichte. Göttingen, 1956.

BÜCHNER, K.: "Die römische Republik im römischen Staatsdenken". Freiburg i.B., 1947.

BURCKHARDT, J.: "A cultura do renascimento na Itália". Brasília, 1991.

CADONI, G.: "Libertà, repubblica e governo misto in Machiavelli". Em: Rivista Internazionale di Filosofia del Diritto, vol. III, 39, 1962.

CARDOSO, S.: “Que república?”. Em: Newton Bignotto, Pensar a República. Belo Horizonte, 2000.

CARPENTER, W.S.: "The Separation of Powers in the eighteenth Century". Em: The American Political Science Review, 22, 1928.

CHABOD, F.: "Scritti su Machiavelli". Torino, 1982.

---- "Scritti sul Rinascimento". Torino, 1981.

CHINARD, G.: "Polybius and the american constitution". Em: Journal of the History of Ideas, vol. I, 1940.

CÍCERO, M. T.: "Da república". Coleção Universidade de Bolso. Rio de Janeiro, $19 ? ?$

COLE, C.: "The Sources and Composition of Polybios Vl". Em: Historia, 13, 1964. 
COLLIVA, P.: "Comuna". Em: N. Bobbio, N. Matteucci e G. Pasquino, Dicionário de Política. São Paulo, 1986.

CONNIFF, J.: "The enlightenment and american political thought. A study of the origins of Madison's Federalist number 10". Em: Political Theory, 8, 1980.

CONSTANT, B.: "De la liberté des anciens comparée à celle des modernes". Em: Cours de Politique Constitutionelle, Bd.II. Genève/Paris, 1982.

COTTA, S.: "Montesquieu, la séparation des pouvoirs et la constitution fédérale Des États-Unis". Em: Revue Internationale d'Histoire Politique et Constitutionelle, vol. I, 2, 1951.

COTTON, J.: "James Harrington as aristotelian". Em: Political Theory, 7, 1979.

COULANGES, F. de: "La cité antique". Paris, 1984.

D'AVACK, L.: "I Nodi del potere. La teoria del governo misto nell'Inghilterra del seicento". Milano, 1979.

DEMONGEOT, M.: "Le meilleur régime politique selon saint Thomas". Paris, 1929.

DERATHÉ, R.: "La Philosophie des lumières en France: Raison et Modération selon Montesquieu". Em: Revue Internationale de Philosophie, 6, 1952.

DIAMOND, M.: "The Federalist". Em: L.Strauss e J.Cropsey, History of Political Philosophy. Chicago, 1972.

DICKINSON, J.: "Checks and Balances". Em: Encyclopaedia of Social Sciences, III, 1950.

DIETZE G.: "Madison's Federalist - A treatise for free government". Em: Georgetown Law Journal, 46, N. 1, 1957.

---- "Hamilton's Federalist - Treatise for Free Government". Em: Cornell Law Quarterly, 42, Nr. 3, 1957.

---- "Hamilton's Federalist - Treatise for Free Government". Em: Cornell Law Quarterly, 42, Nr. 4, 1957.

DRAPER, T.: "Hume \& Madison. The Secrets of Federalist Paper Nr.10". Em: Encounter, 58, 1982.

DUNN, J.: "Democracy. The Unfinished Journey". Oxford, 1992. 
EISENMANN, C.: "L'Esprit des lois et la séparation des pouvoirs". Em: Mélanges Carré de Malberg. Paris, 1933.

EHRENBERG, V.: "Von den Grundformen griechischer Staatsordnung". Heidelberg, 1961.

EHRLICH, E.M.: "Les idées de Montesquieu sur la séparation des pouvoirs et la Constitution Américaine”. Em: Revue du Droit Public, 43, 1926.

FEDERALIST (A.Hamilton, J.Madison \& J.Jay): org. por M. Beloff, Oxford/New York, 1987.

FÉDOU, R.: “L' État au Moyen Age”. Paris, 1971.

FINK, Z. S.: "The Classical Republicans". Evanston, 1945.

FINLEY, M. I: "Aristotle and Economic Analysis”. Em: Past \& Present, 47, 1970.

---- "Democracia antiga e moderna". Rio de Janeiro, 1988.

---- “Economia e Sociedade na Grécia Antiga”. São Paulo, 1989.

FLASCHER, H.: "Ethik und Politik in der Philosophie des Aristoteles". Em: Gymnasium, 78, 1971.

FORSTHOFF, E.: "Der moderne Staat und die Tugend". Em: Tymbos für Wilhelm Ahlmann. Berlin, 1951.

FRIEDRICH, C.J.: "Der Verfassungsstaat der Neuzeit”. Berlin, 1953.

FRITZ, K. von: "Totalitarismus und Demokratie im Alten

Griechenland und Rom". Em: Antike und Abendland, III, 1948.

--- "The theory of the mixed constitution in antiquity". New York, 1975.

GARIN, E.: "Ciência e vida civil no Renascimento italiano". São Paulo, 1996.

GEBHARDT, J.: "The Federalist”. Em: H.Maier, H. Rausch e H. Denzer, Klassiker des politischen Denkens, vol.II. München, 1987.

---- "Der Federalist". Em: Politische Denker. Bayerische Landeszentrale für politische Bildungsarbeit. München, 1966. 
GEORG, S.: "Staat, Verfassung und Politik bei Alexander Hamilton". Em: K.

Kluxen e W. J. Mommsen, Politische Ideologien und nationalstaatliche Ordnung.Festschrift für Theodor Schieder. München/Wien, 1968.

GILBERT, F.: "History. Choice and Commitment". Harvard/London, 1977.

---- "Machiavelli and Guicciardini - Politics and History in Sixteenth Century Florence". New York/London, 1984.

GRAEBER, E.: "Die Lehre von der Mischverfassung bei Polybius". Bonn, 1968.

GRALHER, M.: "Mitte-Mischung-Mäßigung". Em: P. Haugs, Res Publica. Festschrift für D.Sternberger. München, 1977.

GUMMERE, R.M.: "The Classical Ancestry of the United States Constitution". Em: American Quartely, 14, 1962.

HABERMAS, J.: "Die Geschichte von den zwei Revolutionen". Em: Merkur, 20, 1966.

---- "Hannah Arendts Begriff der Macht". Em: Merkur, 30, 1976.

HARRINGTON, J.: "La república de Oceana”. México, 1996.

HASBACH, W.: "Gewaltentrennung, Gewaltenteilung und gemischte Staatsform". Em: Vierteljahrschrift für Sozial- und Wirtschaftsgeschichte, 1916.

HELLMANN, M.: "Geschichte Venedigs in Grundzügen”. Darmstadt, 1989.

HENNIS, W.: "Politik als praktische Wissenschaft". München, 1962.

HIBBERT, C.: "Ascensão e queda da Casa dos Medici”. São Paulo, 1993.

HILL, C.: “A Revolução inglesa de 1640”. São Paulo (?).

--- "O mundo de ponta-cabeça. Idéias radicais durante a Revolução Inglesa de 1640". São Paulo, 1987.

HINTON, R.W.K.: "English Constitutional Doctrines from the Fifteenth Century to the Seventeenth. I. English Constitutional Theories from Sir John Fortescue to Sir John Eliot". Em: The English Historical Review, LXXV, 1960.

IMBODEN, M.: (a) "Die Staatsformen". Basel/Stuttgart, 1959. 
(b) "Montesquieu und die Lehre der Gewaltentrennung". Berlin, 1959.

JAEGER, W.: "Paidéia - A formação do homem grego". São Paulo, 1989.

JASMIN, M.G.: "Interesse bem compreendido e virtude em A Democracia na América". Em: Newton Bignotto, Pensar a República. Belo Horizonte, 2000.

JEFFERSON, T.: "Escritos políticos”. Coleção Os Pensadores, XXIX. São Paulo, 1973.

JOACHIM, H.H.: "The Nicomachean Ethics". Oxford, 1951.

KÄGI, O.W.: "Zur Enstehung, Wandlung und Problematik des

Gewaltenteilungsprinzipes”. Zürich, 1937.

KIELMANSEGG, P.G.: "Die Rechtfertigung politicher Herrschaft”. Freiburg, 1978.

KLUXEN, K.: "Die Herkunft der Lehre von der Gewaltentrennung". Em: J. Engel e M. Klinkenberg, Aus Mittelalter und Neuzeit. Bonn, 1957.

KOSLOWSKI, P.:"Zum Verhältnis von Polis und Oikos bei Aristoteles". München, 1976.

---- $\quad$ "Haus und Geld. Zur aristotelischen Unterscheidung von Politik, Ökonomik und Chrematistk". Em: Philosophisches Jahrbuch, 89, 1979.

KUHFUß, W.: “Mäßigung und Politik”. München, 1975.

LANDI, A: "Madison's political theory". Em: Political Science Review, 6, 1976.

LANGE, U.: "Teilung und Trennung der Gewalten bei Montesquieu". Em: Der Staat, 19, 1980.

LARIVAILLE, P.: “A Itália no tempo de Maquiavel”. São Paulo, 1992.

LOEWENSTEIN, K.: "Political power and the governmental process". Chicago, 1957.

---- $\quad$ "Rom, Venedig, England”. Em: Zeitschrift für Politik, 20, 1973.

MACHIAVELLI, N.: "II principe". Milano, 1986.

---- "Discorsi sopra la prima deca di Tito Livio”. Milano, 1984.

MAIER, H.: "Montesquieu und die Tradition". Em: F. Wiedmann (Hrsg.), Epimeleia, 1964. 
"Verteidigung der Politik". Zürich, 1990.

MANDT, H.: "Tyrannislehre und Widerstandsrecht". Neuwied, 1974.

MANIN, B.: "Principes du Gouvernement Représentatif". Paris, 1995.

MARTINES, L.: "Power and Imagination. City-States in Renaissance Italy". Baltimore, 1988.

MASON, A.T.: "The Federalist - A Split Personality". Em: The American Historical Review, LVII, 1951/52.

MATTEl, R. de: "Dal premachiavellismo all'antimachiavellismo". Firenze, 1969.

---- "Machiavelli e Roma". Em: Quaderni di Studi Romani, Serie I, Nr. 31, 1970.

---- 'La fortuna della formula del 'governo misto' nel dottrinarismo politico italiano del Cinque e del Seicento". Em: Rivista Internazionale di Filosofia del Diritto, IV, 50, 1973.

MATTEUCCI, N.: "Machiavelli, Harrington, Montesquieu e gli ordini di Venezia". Em: II Pensiero Politico, 1970.

---- "La costituzione americana e il moderno costituzionalismo". Em: II Mulino, 36, 1987.

MCILWAIN, C.W.: "Constitucionalism: ancient and modern". London, 1983.

MEHMEL, F.: "Machiavelli und die Antike". Em: Antike und Abendland, III, 1948.

MEIER, C.: "Adel, Aristokratie", "Demokratie" e "Republik". Em: O. Brunner, W. Conze e R. Koselleck, Geschichtliche Grundbegriffe, vol. I e V. Stuttgart, 1979 e 1984.

---- $\quad$ "Die Enstehung des Politischen bei den Griechen". Frankfurt a M., 1983.

MEIKLE, S.: "Aristotle and the political economy of the polis". Em: Journal of Hellenic Studies, 99, 1979.

MONTESQUIEU: "De l'espirit des lois", vol. I e II. Paris, 1979.

MÜNKLER, $H_{\text {.: }}$ "Machiavelli - Die Begründung des politischen Denkens der Neuzeit aus der Krise der Republik Florenz". Frankfurt a.M., 1987. 
NIPPEL, W.: "Mischverfassungstheorie und Verfassungsrealität. Em: Antike und früher Neuzeit". Stuttgart, 1980.

---- 'Klassischer Republikanismus' in der Zeit der Englischen Revolution. Zur Problematik eines Interpretationsmodells". Em: Wolfgang Schuller, Antike in der Moderne. Konstanz, 1985.

NOLTE, P.: "Aristotelische Tradition und amerikanische Revolution. John Adams und das Ende der klassischen Politik". Em: Der Staat, 27, 1988.

OPPEN-RUNDSTEDT, C. von: "Die Interpretation der amerikanischen Verfassung im Federalist". Bonn, 1970.

PAINE, T: "Rights of man". New York/London, 1969.

PALMER, R.R.: "The age of the democratic revolution", vol. I. Princeton, 1974.

PASSARIN D'ENTREVES, A: “La notion de l'État”. Paris, 1969.

PETRELLI, M.: "Philia, eudaimonia, omonimia". Em: Rivista Internationale di Filosofia del Diritto, IV, 59, 1982.

PLATÃO: Obras completas. Madrid, 1977.

POCOCK, J.G.A: "Machiavelli, Harrington, and English Political Ideologies in the Eighteenth Century". Em: William \& Mary Quaterly, vol. III, 22, 1965.

--- "Virtue and Commerce in the Eighteenth Century". Em: The Journal of Interdisciplinary History, 3, 1972/1973.

"The Machiavellian Moment. Florentine Political Thought and the Atlantic Republican Tradition". Princeton/London, 1975.

---- "The Machiavellian Moment Revisited: A Study in History and Ideology". Em: The Journal of Modern History, 53, 1981.

---- "Virtues, Rights, and Manners. A model for Historians of Political Thought". Em: Political Theory, vol.9, 3, 1981.

---- "Machiavelli in the Liberal Cosmos". Em: Political Theory, vol.13, 4, 1985.

PÖSCHL, V. "Römischer Staat und griechisches Staatsdenken bei Cicero". Darmstadt, 1990. 
POLYBIUS: "Historien". Stuttgart, 1973.

PRIDDAT, B. P.: "Die politische Struktur der Aristotelischen Ökonomie". Em: Politische Vierteljahresschrift, 30, 1989.

RAAB, F.: "Harrington, Hobbes, God and Machiavelli". Em: Felix Raab, The English Face of Machiavelli. London, 1964.

RANTZAU, J.A v.: "Politische Wirkungen antiker Vorstellungen bei Montesquieu". Em: Antike und Abendland, V, 1956.

REXINE, J.E.: "Classical political theory and the United States Constitution". Em: Platon, 28, 1976.

RIBEIRO, R.J.: "Democracia versus república”. Em: Newton Bignotto, Pensar a República. Belo Horizonte, 2000.

---- A república”. São Paulo, 2001.

RIEDEL, M.: "Bürgerliche Gesellschaft". Em: O. Brunner, W. Conze e R. Kosellek, Geschichtliche Grundbegriffe, vol. II. Stuttgart, 1975.

RIKLIN, A.: "Die Täuschung der Demokratie". St. Gallen, 1987.

"Aristoteles und die Mischverfassung". Em: H. Batliner, Festgabe zum 60. Geburtstag. Vaduz, 1988.

--- "Montesquieus freiheitliches Staatsmodell. Die Identitat von Machtteilung und Mischverfassung". Em: Politische Vierteljahresschrift, 30, 3, 1989.

ROSSITER, C.: "The legacy of John Adams". Em: Yale Review, 46, 1956/57.

ROSTOCK, M.: "Die antike Theorie der Organisation staatlicher Macht. Studien zur Geschichte der Gewantenteilungslehre". Mensenheim am Glan, 1975.

RUBINSTEIN, N.: "The government of Florence under the Medici (1434-1494)". Oxford, 1997.

RYFFEL, H.: "Metabolé Politeion. Der Wandel der Staatsverfassungen". Bern,1949.

SABINE, G.: "A history of political theory”. Hinsdale/Illinois, 1937/1981.

SASSO, G.: “Niccolò Machiavelli”. Bologna, 1980.

SCANLAN, J.P.: "The Federalist and Human Nature". Em: The Review of Politics, 
21, Nr. 4, 1959.

SCHÄCHER, E.J.: "Die mittlere Verfassung als die für die meisten Staaten durchschnittlich beste Verfassung". Em: Salzburger Jahrbuch für Philosophie, 5/6, 1961/62.

SCHALK, F.: "Montesquieu und die europäische Tradition". Em: Studien zur französischen Aufklärung. Frankfurt a.M., 1977.

SCHILLING,H.: "Das Ethos der Mesotes". Tübingen, 1930.

SCHÜTRUMPF, E.: “Die Analyse der Polis durch Aristoteles”. Amsterdam, 1980.

SENELLART, M.: "Les arts des gouverner. Du regimen médiéval au concept de Gouvernement”. Paris, 1995.

SHACKLETON, R.: "Montesquieu, Bolingbroke and the Separation of Powers". Em: French Studies, 3, 1949.

SHAKESPEARE, W.: “Júlio César”. São Paulo, 1981.

--- $\quad$ "O mercador de Veneza”. Rio de Janeiro, 1999.

--- $\quad$ "Otelo. O mouro de Veneza". Rio de Janeiro, 1999.

SIEGFRIED, W.: "Untersuchungen zur Staatslehre des Aristoteles”. Zürich, 1942.

SKINNER, Q.: “Maquiavel”. São Paulo, 1988.

---- "The italian city-republics". Em: John Dunn, Democracy. Oxford, 1992.

---- (a) "As fundações do pensamento político moderno". São Paulo, 1999.

(b) "Liberdade antes do liberalismo". São Paulo, 1999.

SMITH, M.: "Reason, Passion and Political Freedom in The Federalist". Em: The Journal of Politics, 22, 1960.

SPAHN, P.: “Aristoteles”. Em: I.Fetscher e H.Münkler, Pipers Handbuch der politischen Ideen, vol.I. München, 1988.

---- "Oikos und Polis". Em: Historische Zeitschrift, 231, 1980.

SPURLIN, P. M.: "Montesquieu in America 1760 - 1801". Louisiana, 1940.

STERNBERGER, D.: "Drei Wurzeln der Politik", vol. I e II. Frankfurt a.M., 1978. 
---- "Herrschaft und Vereinbarung". Frankfurt a.M., 1980.

---- "Die neue Politie". Em: Jahrbuch des öffentlichen Rechts, 33, 1984.

(a) "Die Stadt als Urbild". Frankfurt a.M., 1985.

(b) "Der Staat des Aristoteles und der moderne Verfassungsstaat". Bamberg, 1985.

STOURZH, G.: "Die tugendhafte Republik. Montesquieus Begriff der 'vertu' und die Anfänge der Vereinigten Staaten von Amerika". Em: Österreich und Europa. Festg. Für Hugo Hantsch. Graz/ Wien/Köln, 1965.

---- "Alexander Hamilton and the idea of republican government". Stanford, 1970.

--- "Vom aristotelischen zum liberalen Verfassungsbegriff. Zur Entwicklung in England und Nordamerika im 17. Und 18. Jahrhundert". Em: F.Engel-Janossi, G.Klingstein e H.Lutz, Fürst, Bürger, Mensch Untersuchungen zu politischen und soziokulturellen Wandlungsprozessen im vorrevolutionären Europa. München, 1975.

STRASBURGER, H: "Thukydides und die politische Selbstdarstellung der Athener”. Em: Hermes, 86, 1958.

TENENTI, A.: "Florença na época dos Medici". São Paulo, 1973.

TOYNBEE, A.J.: "Helenismo, história de uma civilização". Rio de Janeiro, 1969.

TRAPP, M.: "Über einige Unterschiede zwischen antiker und moderner

Staatsauffassung". Em: Politische Vierteljahresschrift, 29, 1988.

TUCÍDIDES: "História da Guerra do Peloponeso". Brasília, 1987.

WALEY, D.: "The Italian City-Republics". London/New York, 1988.

WALSH, C. M.: "The political science of John Adams. A study in the theory of mixed Government and the bicameral system". New York, 1969.

WELWEI, K-W.: "Die griechische Polis". Stuttgart/Berlin/Köln/Mainz, 1983.

"Demokratie und Masse bei Polybios". Em: Historia, 15, 1966.

WEMBER, V.: "Verfassungsmischung und Verfassungsmitte". Berlin, 1977. 
WESTON, C.C.: "II. The Theory of Mixed Monarchy Under Charles I and After". Em: The English Historical Review, LXXV, 1960.

WOOD, G.S.: "The creation of the American Republic 1776-1787". New York/London, 1969.

---- "Democracy and the American Revolution". Em: John Dunn, Democracy. Oxford, 1992.

WRIGHT JR., B.F.: "The Origins of the Separation of Powers in America". Em: Economica, 13, 1933.

YOUNG, J.P.: "Amerikanisches politisches Denken: Von der Revolution bis zum Bürgerkrieg”. Em: I.Fetscher \& H.Münkler, Pipers Handbuch der politischen Ideen, vol. II. München/Zürich, 1988.

ZILLIG, P.: "Die Theorie von der gemischten Verfassung in ihrer literarischen Entwickelung im Altertum und ihr Verhältnis zur Lehre Lockes und Montesquieus über Verfassung. Würzburg, 1916. 